Cover. Photograph showing Sasco Brook (U.S. Geological Survey station 01208950) from bridge on Hulls Farm Road in Fairfield, CT taken on October 23, 2008. Photograph courtesy of Jason Pollender. 


\title{
Regional Regression Equations to Estimate Flow-Duration Statistics at Ungaged Stream Sites in Connecticut
}

\author{
By Elizabeth A. Ahearn
}

In cooperation with the Connecticut Department of Environmental Protection

Scientific Investigations Report 2010-5052 


\section{U.S. Department of the Interior \\ KEN SALAZAR, Secretary \\ U.S. Geological Survey \\ Marcia K. McNutt, Director}

U.S. Geological Survey, Reston, Virginia: 2010

For more information on the USGS - the Federal source for science about the Earth, its natural and living resources, natural hazards, and the environment, visit http://www.usgs.gov or call 1-888-ASK-USGS

For an overview of USGS information products, including maps, imagery, and publications, visit http://www.usgs.gov/pubprod

To order this and other USGS information products, visit http://store.usgs.gov

Any use of trade, product, or firm names is for descriptive purposes only and does not imply endorsement by the U.S. Government.

Although this report is in the public domain, permission must be secured from the individual copyright owners to reproduce any copyrighted materials contained within this report.

Suggested citation:

Ahearn, E.A., 2010, Regional regression equations to estimate flow-duration statistics at ungaged stream sites in Connecticut: U.S. Geological Survey Scientific Investigations Report 2010-5052, 45 p. 


\section{Contents}

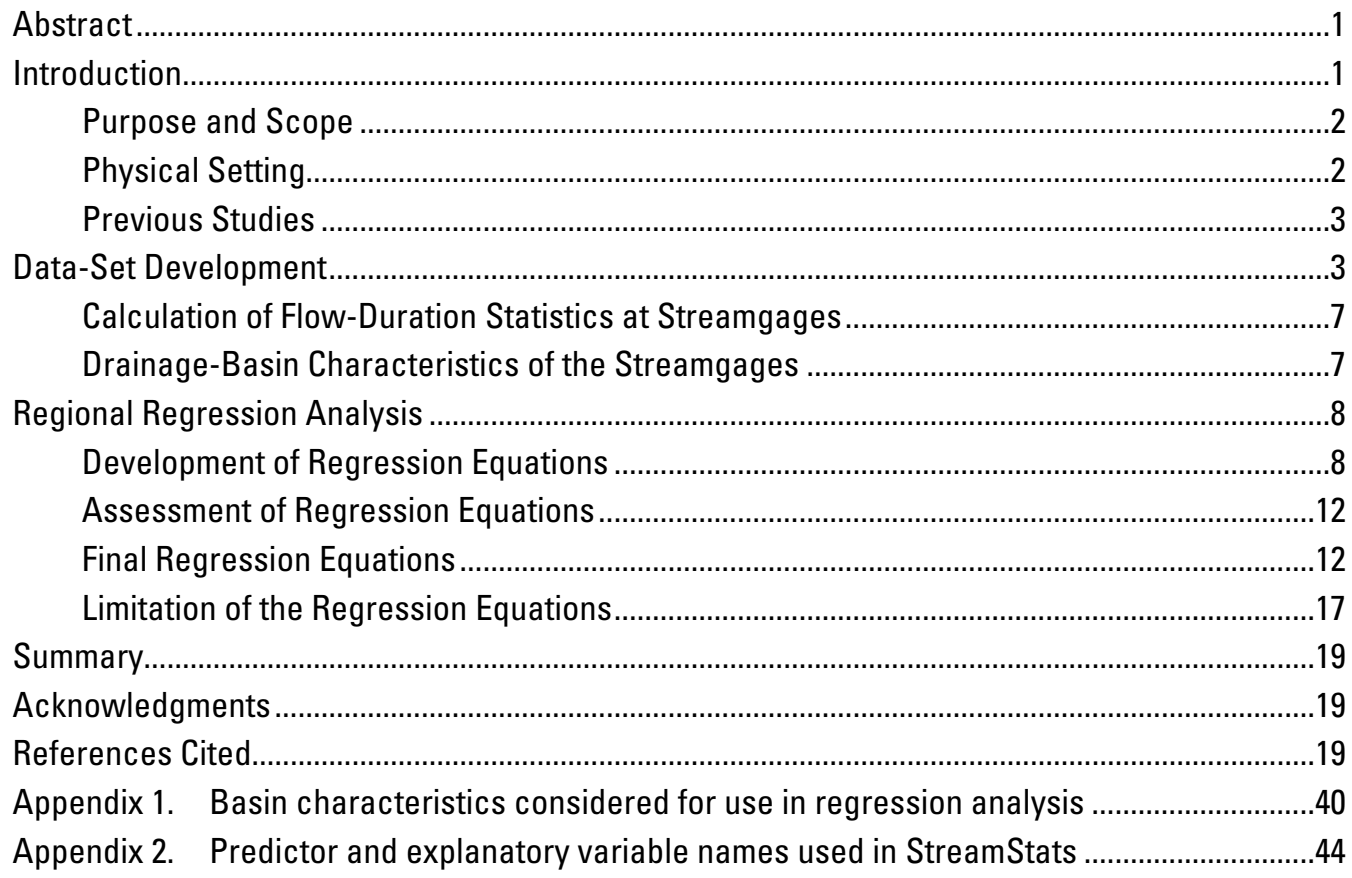

\section{Figures}

1. Map showing locations of continuous-record streamgages considered for regionalizing flow durations in Connecticut.................................................................6

2. Map showing locations of streamgages and short-term continuous-record and partial-record sites in Connecticut and surrounding states considered for use in developing a regression equation to estimate the non-bioperiod 99-percent flow exceedance $\left(\mathrm{O}_{99}\right)$

3. Map showing residuals of the regression equation for the non-bioperiod 99-percent flow exceedance $\left(\mathrm{C}_{99}\right)$ for the study area 


\section{Tables}

1. Bioperiods for which flow-duration statistics and regression equations were developed

2. Descriptions of streamgages with 10 or more years of record considered for regionalizing flow durations in Connecticut.

3. Flow-duration statistics for streamgages with at least 10 years of continuous record in Connecticut and neighboring states considered for regression analysis:

$A$, Actual streamflow; $B$, Normalized streamflow

4. Characteristics of the drainage basins tested for statistical significance in developing regression equations to estimate flow-duration statistics in Connecticut....9

5. Characteristics of the drainage basins used for regionalizing flow-duration statistics in Connecticut: $A$, Continuous streamgages; $B$, Short-term or partial-record streamgages

6. Climate characteristics used for regionalizing flow-duration statistics in Connecticut.

7. Pearson's correlation coefficients of basin characteristic and climate characteristics in Connecticut.

8. Descriptions of short-term streamgages and partial-record sites considered for regionalizing flow-duration statistics in Connecticut....

9. Summary of regression equations for estimating flow-duration statistics at ungaged stream sties in Connecticut and performance metrics

\section{Conversion Factors and Datum}

\begin{tabular}{lcl}
\hline \multicolumn{1}{c}{ Multiply } & By & \multicolumn{1}{c}{ To obtain } \\
\hline inch (in.) & Length & \\
inch (in.) & 2.54 & centimeter $(\mathrm{cm})$ \\
foot (ft) & 25.4 & millimeter $(\mathrm{mm})$ \\
mile (mi) & 0.3048 & meter $(\mathrm{m})$ \\
\hline & 1.609 & kilometer $(\mathrm{km})$ \\
\hline square mile $\left(\mathrm{mi}^{2}\right)$ & Area & \\
square mile $\left(\mathrm{mi}^{2}\right)$ & 259.0 & hectare $(\mathrm{ha})$ \\
\hline & 2.590 & square kilometer $\left(\mathrm{km}^{2}\right)$ \\
\hline cubic foot per second $(\mathrm{ft} / \mathrm{s})$ & Flow rate & \\
cubic foot per second per square & 0.02832 & cubic meter per second $\left(\mathrm{m}^{3} / \mathrm{s}\right)$ \\
mile $\left[\left(\mathrm{ft}^{3} / \mathrm{s}\right) / \mathrm{mi}^{2}\right]$ & 0.01093 & cubic meter per second per square \\
& & kilometer $\left[\left(\mathrm{m}^{3} / \mathrm{s}\right) / \mathrm{km}^{2}\right]$ \\
\hline
\end{tabular}

Temperature in degrees Fahrenheit $\left({ }^{\circ} \mathrm{F}\right)$ may be converted to degrees Celsius $\left({ }^{\circ} \mathrm{C}\right)$ as follows:

${ }^{\circ} \mathrm{C}=\left({ }^{\circ} \mathrm{F}-32\right) / 1.8$

Vertical coordinate information is referenced to the North American Vertical Datum of 1988 (NAVD 88).

Horizontal coordinate information is referenced to the North American Datum of 1983 (NAD 83).

Altitude, as used in this report, refers to distance above the vertical datum. 


\title{
Regional Regression Equations to Estimate Flow-Duration Statistics at Ungaged Stream Sites in Connecticut
}

\author{
By Elizabeth A. Ahearn
}

\section{Abstract}

Multiple linear regression equations for determining flow-duration statistics were developed to estimate select flow exceedances ranging from 25- to 99-percent for six "bioperiods"-Salmonid Spawning (November), Overwinter (December-February), Habitat Forming (March-April), Clupeid Spawning (May), Resident Spawning (June), and Rearing and Growth (July-October) - in Connecticut. Regression equations also were developed to estimate the 25- and 99-percent flow exceedances without reference to a bioperiod. In total, 32 equations were developed. The predictive equations were based on regression analyses relating flow statistics from streamgages to GIS-determined basin and climatic characteristics for the drainage areas of those streamgages. Thirty-nine streamgages (and an additional 6 short-term streamgages and 28 partial-record sites for the non-bioperiod 99-percent exceedance) in Connecticut and adjacent areas of neighboring States were used in the regression analysis. Weighted least squares regression analysis was used to determine the predictive equations; weights were assigned based on record length. The basin characteristics - drainage area, percentage of area with coarse-grained stratified deposits, percentage of area with wetlands, mean monthly precipitation (November), mean seasonal precipitation (December, January, and February), and mean basin elevation - are used as explanatory variables in the equations.

Standard errors of estimate of the 32 equations ranged from 10.7 to 156 percent with medians of 19.2 and 55.4 percent to predict the 25- and 99-percent exceedances, respectively. Regression equations to estimate high and median flows (25- to 75-percent exceedances) are better predictors (smaller variability of the residual values around the regression line) than the equations to estimate low flows (less than 75-percent exceedance). The Habitat Forming (March-April) bioperiod had the smallest standard errors of estimate, ranging from 10.7 to 20.9 percent. In contrast, the Rearing and Growth (July-October) bioperiod had the largest standard errors, ranging from 30.9 to 156 percent. The adjusted coefficient of determination of the equations ranged from 77.5 to 99.4 percent with medians of 98.5 and 90.6 percent to predict the 25- and 99-percent exceedances, respectively.
Descriptive information on the streamgages used in the regression, measured basin and climatic characteristics, and estimated flow-duration statistics are provided in this report. Flow-duration statistics and the 32 regression equations for estimating flow-duration statistics in Connecticut are stored on the U.S. Geological Survey World Wide Web application "StreamStats" (http://water.usgs.gov/osw/streamstats/index.html). The regression equations developed in this report can be used to produce unbiased estimates of select flow exceedances statewide.

\section{Introduction}

The concept that a river has a natural flow regime upon which its ecological integrity depends has been firmly established (Poff and others, 1997). Historically, streamflow standards have been based on a minimum flow regime with no or little natural variability. "In 2005 the Connecticut legislature passed an act expanding existing environmental flow protection to all streams in the state (previously they covered only stocked streams) and required DEP to establish flow regulations to "preserve and protect the natural aquatic life" (State of Connecticut, 2009) and be based, to the maximum extent practicable, on natural variation of flows and water levels while providing for the needs and requirements of public health, flood control, industry, public utilities, water supply, public safety, agriculture, and other lawful uses of such waters." (Smith, 2009).

In early 2010, the State proposed new streamflow standards to safeguard rivers that support a natural flow regime on which the ecological integrity of the riverine ecosystems depends. These streamflow standards and regulations require the quantification of flow exceedances that are based on biological processes or "bioperiods." Bioperiods are defined by the State of Connecticut as the time of year during which certain biological processes that are dependent on flow occur or are likely to occur (State of Connecticut, 2009). In an effort to provide water managers with the ability to determine flow exceedances that are based on bioperiods at ungaged stream

${ }^{1}$ Connecticut Department of Environmental Protection. 
sites in Connecticut, this study was conducted by the U.S. Geological Survey (USGS) in cooperation with the Connecticut Department of Environmental Protection (DEP) and the New England Interstate Water Pollution Control Commission.

To meet future challenges, improved web-based tools are needed to easily obtain streamflow statistics, characteristics of a drainage basin, and other information for planning and management of the water resources. The regression equations developed from this study are included in the USGS StreamStats web-based Geographic Information System (GIS) (Ahearn and others, 2006) to provide users with access to analytical tools and streamflow statistics. StreamStats can be accessed at http://water.usgs.gov/osw/streamstats/index.html and allows users to obtain flow statistics, characteristics of a drainage basin, and other information for user-selected sites on a stream. Using a GIS-based interactive map of Connecticut, the user can 'point and click' on a location and StreamStats will delineate the basin upstream from the selected location and provide flow-duration statistics for the selected location. The user can also 'point and click' on USGS streamgages and receive flow statistics and information about those locations.

\section{Purpose and Scope}

This report presents 32 regression equations for predicting flow-duration statistics for select exceedances from 25- to 99-percent. Thirty of these equations are for particular months or seasons, called bioperiods (table 1), and two equations are not associated with any bioperiod. To differentiate the 25- and 99-percent flow exceedances $\left(\mathrm{Q}_{25}\right.$ and $\left.\mathrm{Q}_{99}\right)$ associated with bioperiods from the $\mathrm{Q}_{25}$ and $\mathrm{Q}_{99}$ that are not based on a particular bioperiod (but on all the data in the streamgage record), the latter are referred to herein as the "non-bioperiod" exceedances. The regression equations were developed using streamflow data collected through September 2007. This report (1) presents estimates of flow-duration statistics for the six bioperiods and the $\mathrm{Q}_{25}$ and $\mathrm{Q}_{99}$ for non-bioperiods at 41 streamgages; (2) describes methods used to develop the regression equations; and (3) describes the accuracy and limitations of the equations.

\section{Physical Setting}

Connecticut encompasses an area of 5,009 $\mathrm{mi}^{2}$ and can be divided into four physiographic regions: western uplands (northwestern part of the state), eastern uplands (northeastern part of the state), central valley (central part of the state), and coastal lowlands. The western uplands generally have the steepest topography; land-surface elevations range from about 500 to $2,300 \mathrm{ft}$ above NAVD 88 with average slopes of about 11 percent. Land-surface elevations in the eastern uplands range from about 500 to $1,300 \mathrm{ft}$ above NAVD 88 with average slopes of about 8 percent. Topographic relief along the coastal lowlands and central valley generally is low with land-surface elevations ranging from 0 to about $500 \mathrm{ft}$ above NAVD 88 (U.S. Geological Survey, 2006). Average slopes along the coastal lowlands and central valley are less than 7 percent.

The surficial geologic materials of Connecticut, described by Stone and others (1992), are primarily glacial deposits. Unconsolidated glacial deposits of varying thickness blanket the bedrock surface across most of the state. Glacial till is the most widespread surficial deposit and is generally thin (less than $15 \mathrm{ft}$ thick). Till was deposited directly by glacial ice, is a nonsorted material ranging in grain size from clay to large boulders, and covers much of the slopes in the State and upland areas. Stratified deposits occur primarily in valleys and lower, flatter areas both inland and along the coast of Connecticut. These materials were laid down by glacial meltwater in streams and lakes and consist of layers of gravel, sand, silt, and clay. These materials are most widespread in the broad central Connecticut Valley and along the coast. Till, bedrock, and fine-grained stratified deposits (very fine sand, silt, and clay) generally have lower permeability than the coarsegrained stratified deposits (gravel and sand), which generally have high permeability.

Table 1. Bioperiods for which flow-duration statistics and regression equations were developed.

\begin{tabular}{|c|c|c|c|}
\hline Bioperiod & Months & Typical flow & Significance \\
\hline Salmonid Spawning & November & Medium & $\begin{array}{l}\text { Increased flows needed for spawning migrations and spawning by salmo- } \\
\text { nids (e.g., Atlantic salmon, brook trout). }\end{array}$ \\
\hline Habitat Forming & March-April & High & $\begin{array}{l}\text { Maintain natural habitat and connectivity with flood plain, channel for- } \\
\text { mation, and flushing and transport of fine-grained sediment. }\end{array}$ \\
\hline Resident Spawning & June & Medium & $\begin{array}{l}\text { Flows needed for spawning migrations and spawning by resident fishes } \\
\text { (e.g., fallfish, white sucker). }\end{array}$ \\
\hline Rearing and Growth & July-October & Low & $\begin{array}{l}\text { Flows needed to sustain and grow aquatic life, including resident and } \\
\text { anadromous fishes, during metabolically active (i.e., warmer) seasons. }\end{array}$ \\
\hline
\end{tabular}


The climate in Connecticut generally is temperate and humid with four distinct seasons. Prevailing westerly winds alternately transport cool, dry, continental-polar, and warm, moist, maritime-tropical air masses into the region, resulting in frequent weather changes. Precipitation is distributed fairly evenly throughout the year and averages about 45 in. annually (based on long-term data from 1920 to 1996 (Miller and others, 2002)). The climate is moderated by maritime influences along coastal regions. Regional differences in topography, elevation, and proximity to the ocean can result in a substantial areal variation in snowfall amounts. Mean snowfall ranges from $30 \mathrm{in}$. along coastal areas, to $40 \mathrm{in}$. inland, to $60 \mathrm{in}$. in the northwestern part of the state (Miller and others, 2002). Average annual temperatures range from $51.7^{\circ} \mathrm{F}$ in coastal areas (Bridgeport) to $49.9^{\circ} \mathrm{F}$ in the central valley (Hartford) (Northeast Region Climate Center, 2009).

Land cover in Connecticut is highly mixed, with forests dominating the north, and densely populated urban areas are prominent along the southwestern-coastal and central-valley regions. Most of the land cover in Connecticut can be classified as forested with little urban development or low population density. The National Land Cover Data (NLCD) for the early 1990s, at a 30-m resolution grid for Connecticut, indicates the following categorization of land cover (MultiResolution Land Characteristics Consortium, 1992):

- 59 percent is forest (deciduous, evergreen, and mixed forest),

- 12 percent is open space developed and low intensity developed (suburban),

- 5.0 percent is high intensity developed (commercial, industrial, and high population density), and

- 24 percent is one of the following - open water, barren land, shrub, grassland, pasture, wetlands, agriculture, and medium intensity developed.

\section{Previous Studies}

Several studies by the USGS that provide estimates of flow-duration statistics in Connecticut have been published, including a series of basin studies (Cervione and others, 1972; Handman and others, 1986; Mazzaferro and others, 1979; Randall and others, 1966; Ryder and others, 1970; Ryder and others, 1981; Thomas and others, 1968; Thomas and others, 1967; Weiss and others, 1982; Wilson and others, 1974). Ahearn (2007) published estimates of flow durations, low-flow frequencies, and monthly median flows for selected streams in Connecticut using data through 2005. That report updated and superseded previously published flow durations, low-flow frequencies, and monthly median flow estimates in Connecticut and was a precursor to the development of regression equations to estimate the flow-duration statistics described in this report. Regional regression techniques to estimate low-flow and flood-flow statistics at ungaged stream sites have been applied in Connecticut (Thomas and Benson, 1970; Cervione and others, 1982; Weiss, 1983; Ahearn, 2004). Studies published by USGS within the last 20 years that regionalized flow-duration statistics in Massachusetts include Archfield and others (2010) and Ries and Friesz (2000).

\section{Data-Set Development}

Data from about 100 streamgages with 10 or more years of daily mean flows in Connecticut and in the neighboring states of Rhode Island, Massachusetts, and New York were retrieved from the USGS National Water Inventory System (NWIS) database at http://nwis.waterdata.usgs.gov/usa/nwis/discharge and considered for the regression study (Ahearn, 2007). Subsequently, Connecticut DEP and USGS made a rigorous effort to identify and eliminate any of the streamgages that were impacted by anthropogenic activities (such as flow augmentation, diversions, or water-supply/industrial withdrawals in the upstream drainage basin). After evaluating all available 100 flow records, 41 continuous-record streamgages, 6 short-term streamgages and 28 partial-record sites ${ }^{2}$ met the criterion of a natural or near-natural flow regime (table 2 and fig. 1). Of the 41 continuous-record streamgages, 27 are in Connecticut; 10 of these were active in 2007. The 6 short-term streamgages and 28 partial-record sites are located in Connecticut and were available for regionalization of the $\mathrm{Q}_{99}$ without reference to a bioperiod. In a companion study that preceded the regression analysis presented in this report, several low-flow statistics, including the $\mathrm{Q}_{99}$, were estimated for the short-term streamgages and partial-record sites (Ahearn, 2007).

Streamgages outside Connecticut were included in the regionalization of flow-duration statistics because of the sparse coverage of long-term streamgages with natural flow conditions within the State. These streamgages are within $15 \mathrm{mi}$ of the State line. Inclusion of more streamgages may provide a more representative sample of the range of physiographic characteristics of Connecticut.

The flow records for the 41 continuous-record streamgages ranged from 10 to 95.2 years with an average of 36.2 years. The flow records for the short-term streamgages and partial-record sites ranged from 3.5 to 19.6 years with an average of 13.1 years. Fourteen continuous-record streamgages had flow records less than 20 years. Twenty or 30 years of flow record would have provided a broader representation of flow variability in the region and would have minimized the influence of unusually wet or dry periods. However, using a longer minimum record length would have decreased the number of available streamgages in the region of the study that already had limited data coverage. The additional streamgages in the regression analysis can

\footnotetext{
${ }^{2} \mathrm{~A}$ short-term streamgage has continuous-stage recording equipment with less than 10 years of record. A partial-record site has periodic streamflow measurements and does not have continuous stage-recording equipment.
} 


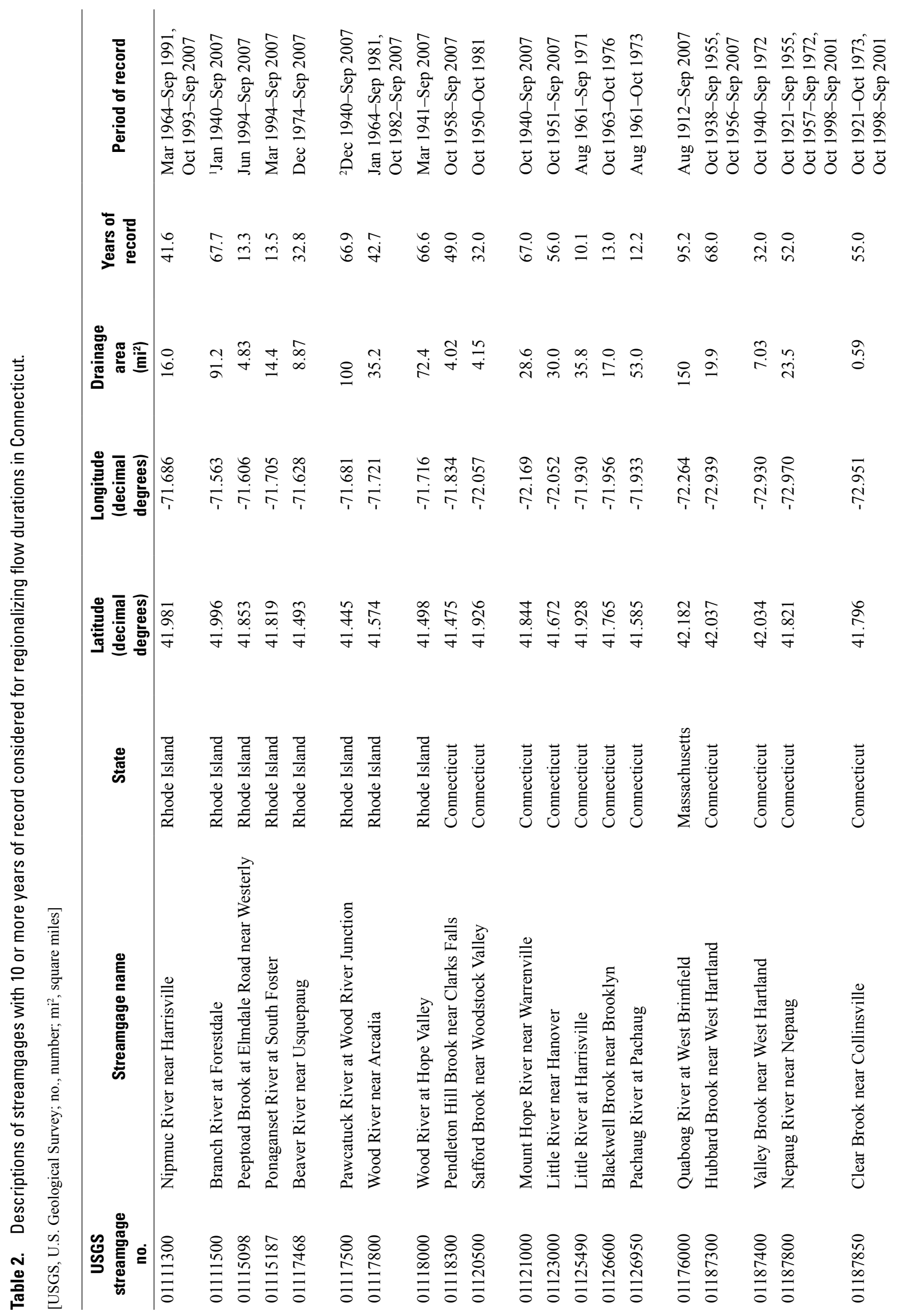




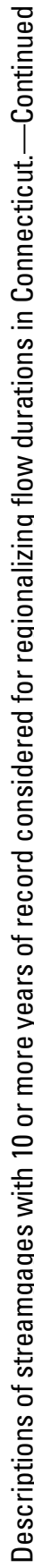

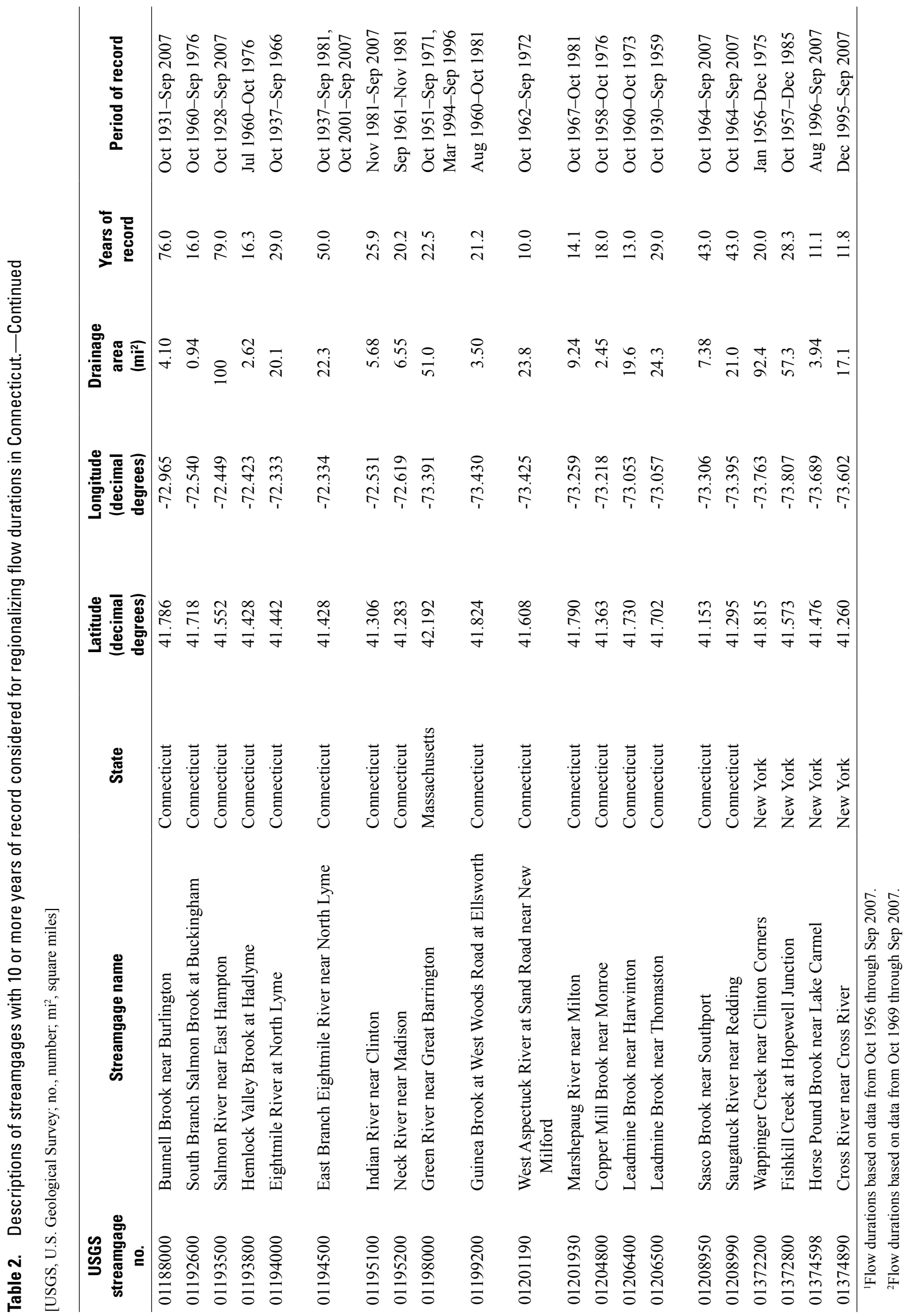




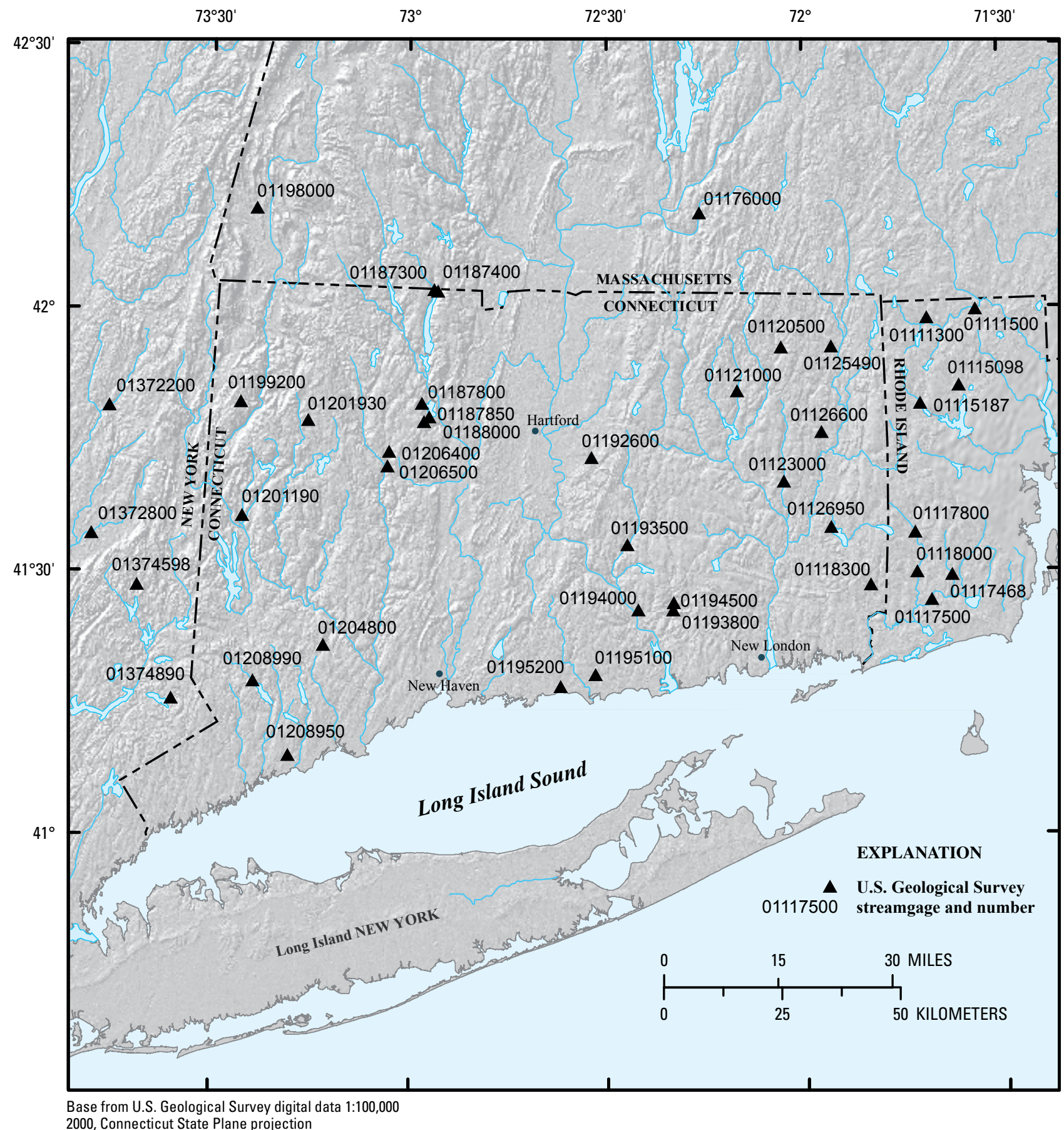

Figure 1. Locations of continuous-record streamgages considered for regionalizing flow durations in Connecticut. 
result in a set of equations that are more robust. Although an effort was made by Connecticut DEP and USGS to eliminate streamgages with flow records that have been impacted by anthropogenic activities, the possibility exists that some of the flow records, particularly those in neighboring states, were affected by anthropogenic impacts.

Plots of the data revealed some streamgages are outliers; that is, data values from them depart substantially from the rest of the data. For example, Clear Brook (station 01187850), with a drainage area of only $0.59 \mathrm{mi}^{2}$, is an outlier. The groundwater drainage area and surface-water drainage area in this basin are not coincident. Also, Marshepaug River (station 01201930), with a drainage area of $9.24 \mathrm{mi}^{2}$, is an outlier. The stage-discharge relation is not well defined at this streamgage and consequently is considered less reliable than at the other streamgages. These two outlier streamgages were dropped from the regression analysis, leaving 39 streamgages.

\section{Calculation of Flow-Duration Statistics at Streamgages}

Flow durations represent the percentage of time that a given flow, measured over a specified time interval, has been equaled or exceeded during that time interval. For example, a 99-percent flow exceedance $\left(\mathrm{Q}_{99}\right)$ represents a streamflow that is equaled or exceeded 99 percent of the time. Flow values at or below the $\mathrm{Q}_{99}$ indicate extremely low flows. Conversely, a 25-percent flow exceedance $\left(Q_{25}\right)$ represents a daily-mean streamflow that is equaled or exceeded 25 percent of the time. Flow values at or above the $\mathrm{Q}_{25}$ represent high-flow conditions because 75 percent of all daily mean streamflows in the record are smaller than that flow. Typically, flow durations characterize the range of flows for the period over which data were collected. The streamflow data from the streamgages used in this study are based on periods of record with varying starting and ending years (table 2) with the earliest starting in 1912 and the most recent ending in September 2007.

Flow-duration statistics are computed by sorting the daily mean streamflows for the period of record from the largest value to the smallest value and assigning each streamflow value a rank, starting with 1 for the largest value. The exceedance probabilities are then computed using the Weibull formula for computing plotting position (Helsel and Hirsch, 1992):

$$
P=100 *[M /(n+1)]
$$

where

$$
\begin{aligned}
& P \quad=\text { the probability that a given flow will be } \\
& \quad \text { equaled or exceeded (percentage of time) }, \\
& M \quad=\text { the ranked position (dimensionless), and } \\
& n \quad=\text { the number of events for the period of } \\
& \quad \text { record (dimensionless). }
\end{aligned}
$$

Flow-duration statistics, in units of cubic feet per second, were derived from historical data through September 2007 (table 3A, at back of this report). The flow exceedances were computed from daily mean flows for the period of record. Seasonal and monthly flow exceedances, representative of the bioperiods, were computed from daily mean flows for the period of record during each of the six bioperiods. For example, the $\mathrm{Q}_{99}$ in the Salmonid Spawning bioperiod is calculated using just daily mean flows for every November in the period of record. Similarly, the $\mathrm{Q}_{99}$ for the Overwinter bioperiod is calculated using all the daily mean flows for every December, January, and February in the period of record. Flow-duration statistics were computed using a commercial statistics and data-management software package called Spotfire $\mathrm{S}+{ }^{\circledR}$ (TIBCO Software Inc., 2008).

To compare flow-duration statistics across basins, the flows were divided by their respective drainage areas (table 3B, at back of this report). The normalized nonbioperiod $\mathrm{Q}_{99}$ ranged from 0.0 to $0.90 \mathrm{ft}^{3} / \mathrm{s} / \mathrm{mi}^{2}$; the average value was $0.09 \mathrm{ft}^{3} / \mathrm{s} / \mathrm{mi}^{2}$. For the Rearing and Growth bioperiod (low-flow conditions), the normalized $\mathrm{Q}_{99}$ ranged from 0.0 to $0.90 \mathrm{ft}^{3} / \mathrm{s} / \mathrm{mi}^{2}$, the average value was $0.08 \mathrm{ft}^{3} / \mathrm{s} / \mathrm{mi}^{2}$. With the exclusion of Clear Brook, which is a low-flow outlier, the normalized non-bioperiod $\mathrm{Q}_{99}$ ranged from 0.0 to $0.33 \mathrm{ft}^{3} / \mathrm{s} / \mathrm{mi}^{2}$, the average value was $0.07 \mathrm{ft}^{3} / \mathrm{s} / \mathrm{mi}^{2}$. For the Rearing and Growth bioperiod, the normalized $\mathrm{Q}_{99}$ ranged from 0.0 to $0.30 \mathrm{ft}^{3} / \mathrm{s} / \mathrm{mi}^{2}$, the average value was $0.05 \mathrm{ft}^{3} / \mathrm{s} / \mathrm{mi}^{2}$. During high-flow conditions, the normalized non-bioperiod $\mathrm{Q}_{25}$ ranged from 1.56 to $3.56 \mathrm{ft}^{3} / \mathrm{s} / \mathrm{mi}^{2}$; the average value was $2.41 \mathrm{ft}^{3} / \mathrm{s} / \mathrm{mi}^{2}$. For the Habitat Forming bioperiod (highflow conditions), the normalized $\mathrm{Q}_{25}$ ranged from 3.19 to $5.69 \mathrm{ft}^{3} / \mathrm{s} / \mathrm{mi}^{2}$; the average value was $4.26 \mathrm{ft}^{3} / \mathrm{s} / \mathrm{mi}^{2}$. A common time period was not used to derive the normalized flow values, and the differences in flows per square mile between the streamgages are partly attributed to the varying record lengths.

Previously derived flow-duration statistics for the $\mathrm{Q}_{99}$ from short-term streamgages and partial-record sites were used in conjunction with the 39 continuous-record streamgages in the regression analysis of the non-bioperiod $\mathrm{Q}_{99}$. In a previous study (Ahearn, 2007), the $\mathrm{Q}_{99}$ was derived using the MOVE3 method (Vogel and Stedinger, 1985) for 7 short-term continuous-record and 31 partial-record sites in Connecticut; flow-duration statistics were not computed for the bioperiods. The flow-duration statistics at the short-term continuous-record streamgages and partial-record sites were calculated based on the relation between same-day flows at the short-term streamgages and partial-record sites and concurrent daily mean flows at a nearby continuous-record streamgage with natural flow conditions.

\section{Drainage-Basin Characteristics of the Streamgages}

Flow characteristics of streams are directly related to the physical, land-cover, geologic, and climatic features of 
the basin. Characteristics of the drainage basin were selected for use as potential explanatory variables in the regression analysis based on their theoretical relation to flows, results of previous studies in similar hydrologic regions, and the ability to measure the basin characteristics using digital data sets and GIS technology. Measuring the basin characteristics with GIS technology facilitates automation of the process and solving the regional regression equations in StreamStats.

A GIS database was set up to store the characteristics of the drainage basins measured for the streamgages used in the regression analysis. The name, units of measure, method of measurement, and source of data for each measured basin characteristic are listed in appendix 1. The drainage-basin characteristics considered for use in the Connecticut regression analysis are listed in table 4 , and the measured values are in tables 5 (physical, land-cover, and geologic characteristics) and 6 (climate characteristics) (at the back of this report).

\section{Regional Regression Analysis}

Multiple linear regression (MLR) analysis was used to develop equations to predict flow-duration statistics at ungaged stream sites in Connecticut. MLR analysis provides a mathematical equation of the relation between a response variable (flow exceedance) and one or more explanatory variables (basin characteristics). After developing such equations, if the explanatory variables are known (can be measured or quantified) at the ungaged locations, the fitted equations can be used to make predictions of the response variables.

\section{Development of Regression Equations}

Basic plots and initial regression runs using all the data were used to decide if variable transformations were needed. The plots indicated that a $\log$ transformation was needed in order to meet the assumptions of linear regression. Logarithmic (base-10) transformations were made of the flow exceedances (response variable) and basin characteristics (explanatory variables) to linearize the relation between the explanatory variables and the response variables, to stabilize the variance by obtaining equal variance about the regression line, and to improve the spread of the data.

Plots of transformed and untransformed explanatory variables also were examined to eliminate redundant (correlated) explanatory variables in the variable selection process of the regression analysis. The explanatory variables were selected based on their relation to flow and correlation to other basin characteristics using Pearson's correlation coefficient (R). If a moderate correlation ( $R$ less than 0.6) existed between two explanatory variables, the two variables were evaluated individually in the variable selection process. Pearson's correlation coefficients were computed for each explanatory variable. If an explanatory variable showed low correlation to flow and high correlation to another explanatory variable with high correlation to flow, it was eliminated from consideration in the study. Several explanatory variables were found to be moderately or highly correlated to other explanatory variables (table 7).

Two automated statistical methods for selecting explanatory variables were used in the regression analysis, "all-possible subsets" and "stepwise selection." Both selection methods determined the statistical contribution of the explanatory variable that was entered into the equation and variables were retained or deleted based on their statistical importance. In "all-possible subsets," all the equations created from all possible combinations of explanatory variables were examined and the coefficient of determination $\left(\mathrm{R}^{2}\right)$ was used to check for the best combination of explanatory variables. With this method, each explanatory variable can be included or excluded independently of the other explanatory variables. Efroymson's stepwise-selection method (Efroymson, 1960) is similar to forward selection, which involves testing variables one by one and including them in the equation if they are statistically significant, except that when each new variable is added to the subset, partial correlations are considered to see if any of the variables in the subset should be dropped. When basin characteristics were found to be highly correlated, only one basin characteristic at a time was used in the selection process.

To identify the best combination of explanatory variables, different equations from the regression analysis were compared based on the adj- $\mathrm{R}^{2}$, Mallow's Cp, PRESS statistics, and $\mathrm{SE}_{\mathrm{r}}$.

- Adjusted-R-squared $\left(\operatorname{adj}-R^{2}\right)$, also called the adjusted coefficient of determination, is a measure of the percentage of the variation explained by the explanatory variables of the equation and is adjusted for the number of parameters in the equation;

- Mallow's Cp statistic is an estimate of the standardized mean square error of prediction. Cp statistic is a compromise between maximizing the explained variance by including all relevant variables and minimizing the standard error by keeping the number of variables as small as possible (Helsel and Hirsch, 1992);

- Predicted Residual Sum of Squares (PRESS) statistic is a validation-type estimator of error (Helsel and Hirsch, 1992). PRESS uses n-1 observations to develop the equation, then estimates the value of the observation that was left out. The process is repeated for each observation and the prediction errors are squared and summed;

- Standard error of estimate ( $\mathrm{SE}_{\mathrm{r}}$, in percent), also referred to as the root-mean-squared error of the residuals, is the standard deviation of observed values about the regression line. It is computed by dividing the unexplained variation or the error sum of squares by its degrees of freedom. In this study, the $\mathrm{SE}_{\mathrm{r}}$ is based on one standard deviation. 
Table 4. Characteristics of the drainage basins tested for statistical significance in developing regression equations to estimate flow-duration statistics in Connecticut.

[NAVD, North American Vertical Datum of 1988; NLCD, National Land Cover Dataset; NWI, National Wetlands Dataset; PRISM, Parameter-elevation Regressions on Independent Slopes Model (Prism Group, Oregon Climatic Service of Oregon State University); SSURGO, Soil Survey Geographic Database (Natural Resources Conservation Service, 2007)]

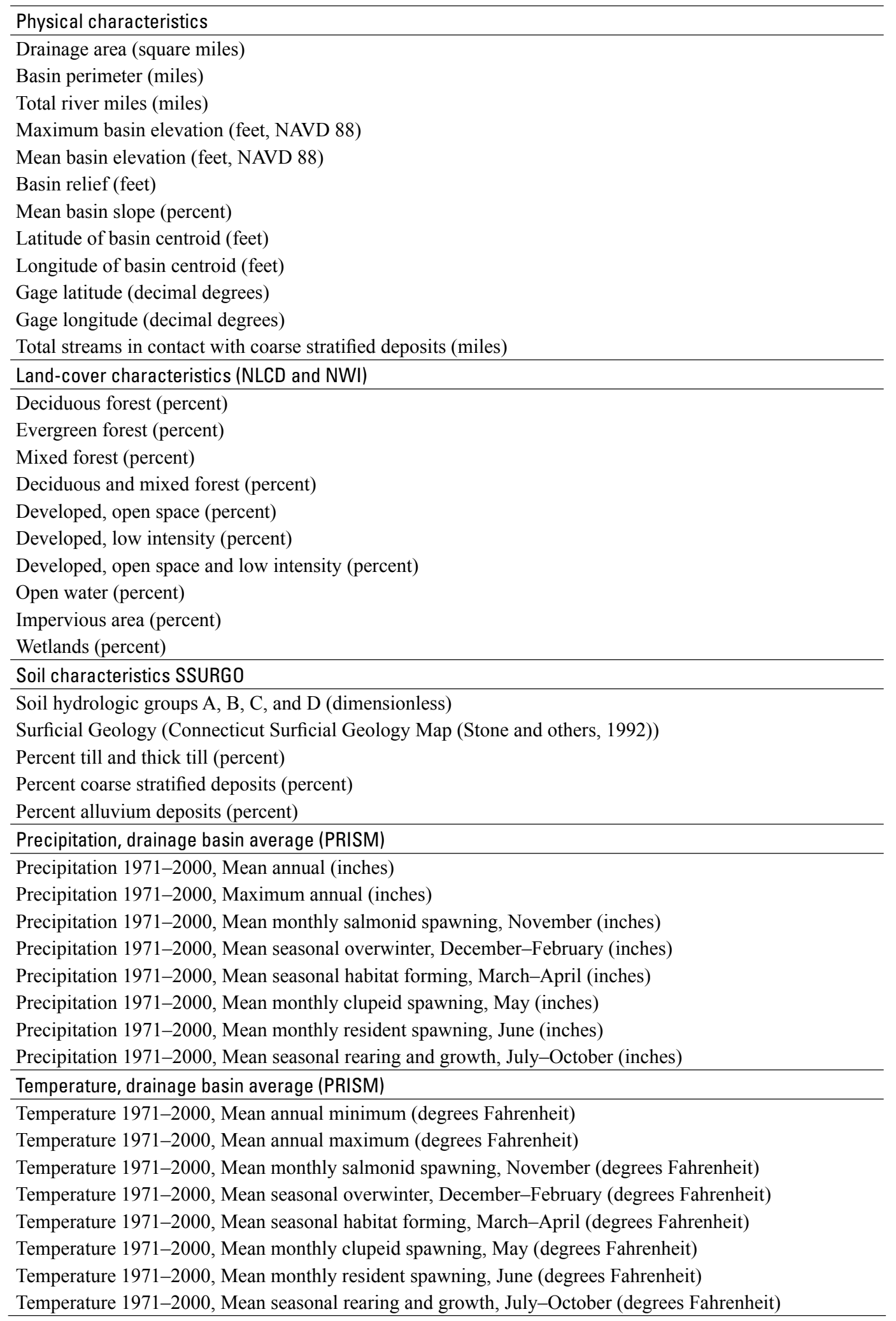


Table 7. Pearson's correlation coefficients of basin characteristic and climate characteristics in Connecticut.

[Red italics, basin characteristics used in regression equations; shaded, bold figures are correlations equal to or greater than 0.6]

\begin{tabular}{|c|c|c|c|c|c|c|c|c|c|c|c|c|c|c|c|c|c|c|c|}
\hline & 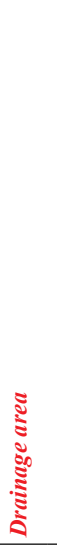 & 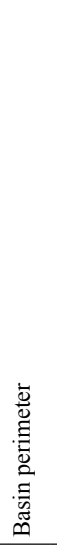 & 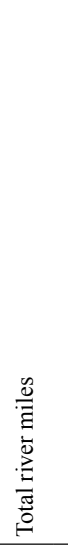 & 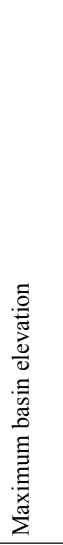 & 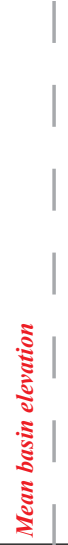 & 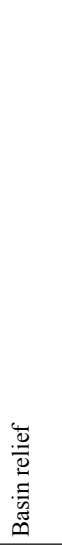 & 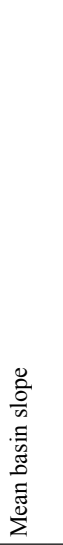 & 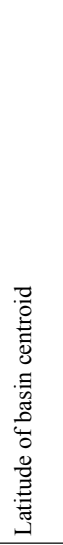 & 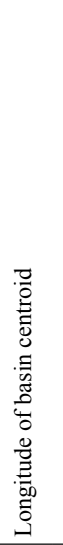 & 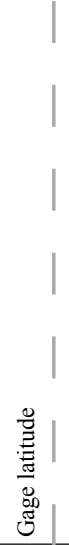 & 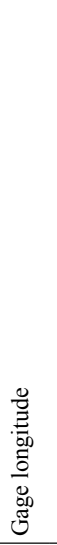 & 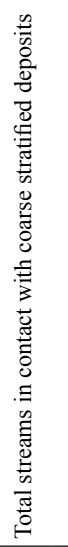 & 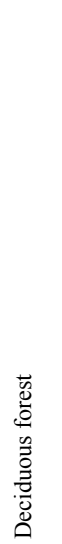 & 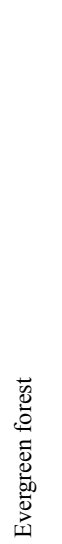 & 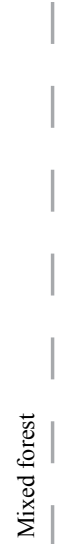 & 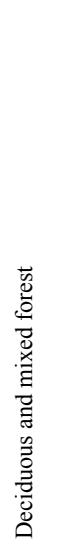 & 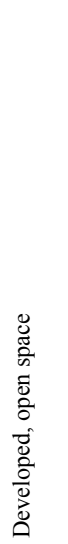 & 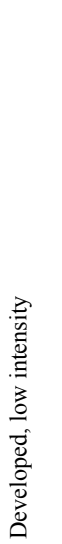 & 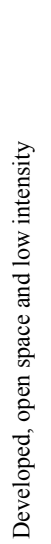 \\
\hline Drainage area & 1.0 & & & & & & & & & & & & & & & & & & \\
\hline Basin perimeter & 0.9 & 1.0 & & & & & & & & & & & & & & & & & \\
\hline Total river miles & 1.0 & 0.9 & 1.0 & & & & & & & & & & & & & & & & \\
\hline Maximum basin elevation & 0.2 & 0.2 & 0.1 & 1.0 & & & & & & & & & & & & & & & \\
\hline Mean basin elevation & -0.1 & -0.0 & -0.1 & 0.9 & 1.0 & & & & & & & & & & & & & & \\
\hline Basin relief & 0.4 & 0.6 & $0 . \overline{3}$ & 0.8 & 0.5 & 1.0 & & & & & & & & & & & & & \\
\hline Mean basin slope & -0.0 & 0.1 & -0.1 & 0.7 & 0.6 & 0.7 & 1.0 & & & & & & & & & & & & \\
\hline Latitude of basin centroid & 0.2 & 0.1 & 0.2 & -0.6 & -0.5 & -0.4 & -0.7 & 1.0 & & & & & & & & & & & \\
\hline Longitude of basin centroid & 0.3 & 0.3 & 0.3 & 0.6 & 0.6 & 0.5 & 0.2 & 0.2 & 1.0 & & & & & & & & & & \\
\hline Gage latitude & 0.3 & 0.2 & 0.2 & 0.6 & 0.7 & 0.4 & 0.2 & 0.1 & 1.0 & 1.0 & & & & & & & & & \\
\hline Gage longitude & 0.1 & 0.0 & 0.2 & -0.6 & -0.5 & -0.5 & -0.7 & 1.0 & 0.2 & 0.2 & 1.0 & & & & & & & & \\
\hline Total streams in contact with coarse-stratified deposits & 0.8 & 0.6 & 0.9 & -0.1 & -0.2 & 0.1 & -0.3 & 0.4 & 0.2 & 0.1 & 0.3 & 1.0 & & & & & & & \\
\hline Deciduous forest & -0.5 & -0.5 & -0.5 & -0.0 & 0.1 & -0.2 & 0.3 & -0.1 & -0.2 & -0.2 & -0.1 & -0.5 & 1.0 & & & & & & \\
\hline Evergreen forest & 0.3 & 0.2 & 0.3 & 0.1 & 0.1 & 0.1 & -0.0 & 0.3 & 0.4 & 0.4 & 0.3 & 0.4 & -0.6 & 1.0 & & & & & \\
\hline Mixed forest & 0.1 & 0.1 & 0.1 & 0.5 & $0.5^{1}$ & 0.4 & 0.2 & 0.0 & 0.6 & 0.6 & 0.0 & -0.0 & -0.4 & 0.3 & 1.0 & & & & \\
\hline Deciduous and mixed forest & -0.5 & -0.5 & -0.5 & 0.3 & 0.4 & 0.1 & 0.4 & -0.1 & 0.1 & 0.1 & -0.1 & -0.5 & 0.8 & -0.4 & 0.2 & 1.0 & & & \\
\hline Developed, open space & -0.2 & -0.3 & -0.2 & -0.4 & -0.3 & -0.3 & -0.1 & -0.3 & -0.6 & -0.6 & -0.3 & -0.2 & -0.2 & -0.1 & -0.3 & -0.3 & 1.0 & & \\
\hline Developed, low intensity & -0.0 & -0.2 & -0.0 & -0.4 & -0.3 & -0.3 & -0.3 & -0.0 & -0.3 & -0.2 & -0.0 & 0.1 & -0.4 & 0.1 & -0.2 & -0.5 & 0.6 & 1.0 & \\
\hline Developed, open space and low intensity & -0.2 & -0.3 & -0.2 & -0.4 & -0.4 & -0.4 & -0.2 & -0.3 & -0.5 & -0.5 & -0.3 & -0.1 & -0.3 & -0.0 & -0.3 & -0.4 & 0.9 & 0.8 & 1.0 \\
\hline Open water & 0.5 & 0.4 & 0.5 & 0.1 & -0.0 & 0.2 & 0.0 & 0.1 & 0.0 & 0.0 & 0.1 & 0.5 & -0.2 & 0.2 & 0.0 & -0.2 & -0.2 & -0.2 & -0.2 \\
\hline Impervious area & 0.0 & -0.1 & 0.1 & -0.4 & -0.4 & -0.3 & -0.4 & -0.1 & -0.3 & -0.3 & -0.1 & 0.1 & -0.4 & 0.0 & -0.2 & -0.5 & 0.7 & 0.9 & 0.9 \\
\hline Wetlands & 0.4 & 0.3 & 0.4 & -0.2 & -0.2 & -0.1 & -0.4 & 0.6 & 0.1 & 0.1 & 0.6 & 0.7 & -0.2 & 0.4 & -0.1 & -0.2 & -0.3 & -0.1 & -0.3 \\
\hline Hydrologic soil type A & 0.4 & 0.3 & 0.4 & 0.0 & -0.1 & 0.1 & -0.1 & 0.2 & 0.2 & 0.2 & 0.2 & 0.5 & -0.1 & 0.3 & -0.2 & -0.3 & -0.2 & -0.0 & -0.2 \\
\hline Hydrologic soil type B & -0.1 & -0.0 & -0.1 & 0.2 & 0.3 & 0.1 & 0.1 & -0.1 & 0.3 & 0.3 & -0.1 & -0.2 & -0.2 & 0.2 & 0.2 & -0.1 & -0.0 & 0.2 & 0.0 \\
\hline Hydrologic soil type C & -0.1 & 0.0 & -0.1 & 0.5 & 0.5 & 0.3 & 0.1 & -0.1 & 0.5 & 0.5 & -0.0 & -0.2 & -0.3 & 0.1 & 0.8 & 0.2 & -0.3 & -0.3 & -0.3 \\
\hline Hydrologic soil type D & -0.4 & $\overline{-0.3}$ & -0.4 & -0.5 & $\overline{-0.4}$ & $-\overline{-0.4}$ & -0.1 & -0.1 & -0.7 & -0.7 & -0.1 & $\overline{-0.3}$ & 0.4 & -0.5 & -0.4 & $\overline{0.2}$ & $0 . \overline{4}$ & 0.1 & $\overline{0.3}$ \\
\hline Hydrologic soil type D and A/D and C/D & -0.4 & -0.4 & -0.4 & -0.4 & -0.3 & -0.3 & -0.0 & -0.2 & -0.6 & -0.6 & -0.2 & -0.4 & 0.4 & -0.5 & -0.3 & 0.3 & 0.4 & 0.1 & 0.3 \\
\hline Percent till and thick till & -0.4 & -0.4 & -0.4 & 0.1 & 0.3 & -0.1 & 0.2 & -0.2 & -0.0 & -0.1 & -0.1 & -0.5 & 0.4 & -0.5 & 0.3 & 0.6 & 0.1 & -0.3 & -0.0 \\
\hline Percent coarse stratified deposits & 0.3 & 0.2 & 0.3 & -0.3 & -0.4 & -0.2 & -0.4 & 0.5 & 0.1 & 0.1 & 0.5 & 0.5 & -0.4 & 0.6 & -0.2 & -0.5 & -0.1 & 0.4 & 0.1 \\
\hline Percent alluvium deposits & -0.1 & 0.1 & -0.1 & 0.2 & 0.2 & 0.1 & 0.2 & -0.2 & -0.0 & -0.0 & -0.2 & -0.3 & 0.1 & -0.2 & -0.1 & 0.1 & -0.2 & -0.2 & -0.2 \\
\hline Mean annual precipitation & -0.4 & -0.4 & $-0 . \overline{4}$ & -0.1 & 0.1 & $-\overline{-0.3}$ & -0.1 & -0.0 & $\overline{-0.2}$ & $-0 . \overline{2}$ & -0.0 & -0.3 & 0.2 & -0.2 & 0.2 & $\overline{0.3}$ & $0 . \overline{1}$ & 0.1 & $\overline{0.1}$ \\
\hline Maximum annual precipitation & -0.3 & -0.3 & -0.3 & 0.0 & 0.2 & -0.1 & 0.1 & -0.2 & -0.2 & -0.1 & -0.2 & -0.3 & 0.1 & -0.2 & 0.3 & 0.3 & 0.1 & 0.1 & 0.1 \\
\hline Mean monthly precipitation, salmonid spawning (Nov) & -0.2 & -0.3 & -0.2 & -0.6 & -0.4 & -0.6 & -0.5 & 0.6 & -0.2 & -0.2 & 0.7 & -0.0 & 0.1 & -0.0 & 0.1 & 0.2 & -0.1 & 0.1 & -0.0 \\
\hline Mean seasonal precipitation, overwinter (Dec-Feb) & -0.2 & -0.3 & -0.1 & -0.6 & -0.4 & -0.6 & -0.6 & 0.7 & -0.2 & -0.2 & 0.7 & 0.0 & 0.1 & -0.0 & 0.1 & 0.2 & -0.2 & 0.0 & -0.1 \\
\hline Mean seasonal precipitation, habitat forming (Mar-Apr) & -0.4 & -0.4 & -0.3 & -0.6 & -0.4 & -0.6 & -0.5 & 0.4 & -0.4 & -0.4 & 0.4 & -0.1 & 0.2 & -0.2 & -0.0 & 0.2 & 0.1 & 0.2 & 0.2 \\
\hline Mean monthly precipitation, clupeid spawning (May) & -0.2 & $\overline{-0.2}$ & $-0 . \overline{3}$ & 0.5 & 0.6 & 0.4 & 0.6 & -0.9 & $\overline{-0.1}$ & $-0 . \overline{1}$ & -0.9 & $\overline{-0.3}$ & 0.1 & $-0.2^{-}$ & 0.2 & $\overline{0.2}$ & 0.3 & 0.1 & 0.3 \\
\hline Mean monthly precipitation, resident spawning (Jun) & -0.2 & -0.2 & -0.3 & 0.6 & 0.7 & 0.3 & 0.5 & -0.8 & 0.1 & 0.1 & -0.8 & -0.4 & 0.1 & -0.2 & 0.3 & 0.3 & 0.2 & 0.0 & 0.1 \\
\hline Mean seasonal precipitation, rearing and growth (Jul-Oct) & -0.3 & -0.2 & -0.3 & 0.5 & 0.6 & 0.2 & 0.5 & -0.6 & 0.0 & 0.1 & -0.6 & -0.5 & 0.1 & -0.1 & 0.2 & 0.2 & 0.1 & -0.0 & 0.1 \\
\hline Mean annual minimum temperature & -0.1 & -0.2 & -0.1 & -0.8 & -0.8 & -0.6 & -0.4 & 0.1 & -0.8 & -0.8 & 0.1 & 0.1 & 0.1 & -0.2 & -0.6 & -0.3 & 0.6 & 0.4 & 0.5 \\
\hline Mean annual maximum temperature & -0.0 & -0.0 & -0.0 & -0.7 & -0.8 & -0.4 & -0.3 & 0.1 & -0.8 & -0.8 & 0.1 & 0.0 & 0.1 & -0.2 & -0.7 & -0.4 & 0.5 & 0.3 & 0.5 \\
\hline Mean monthly temperature, salmonid spawning ( $\overline{(\overline{N o v})}$ & -0.0 & $\overline{-0.1}$ & -0.0 & -0.9 & -0.9 & $-\overline{0.5}$ & -0.5 & 0.3 & -0.8 & -0.8 & 0.3 & 0.1 & 0.1 & -0.1 & -0.7 & $\overline{-0.4}$ & $0 . \overline{4}$ & 0.3 & 0.5 \\
\hline Mean seasonal temperature, overwinter (Dec-Feb) & -0.1 & -0.1 & -0.1 & -0.5 & -0.6 & -0.3 & -0.1 & -0.2 & -0.8 & -0.8 & -0.3 & -0.1 & -0.0 & -0.3 & -0.5 & -0.3 & 0.7 & 0.4 & 0.7 \\
\hline Mean seasonal temperature, habitat forming (Mar-Apr) & -0.1 & -0.0 & -0.1 & -0.6 & -0.7 & -0.4 & -0.2 & -0.0 & -0.8 & -0.8 & -0.0 & -0.0 & 0.1 & -0.2 & -0.7 & -0.3 & 0.5 & 0.3 & 0.5 \\
\hline Mean monthly temperature, clupeid spawning (May) & -0.0 & 0.1 & -0.1 & -0.2 & -0.4 & -0.0 & 0.1 & -0.3 & -0.5 & -0.4 & -0.3 & -0.2 & 0.0 & -0.1 & -0.5 & -0.3 & 0.4 & 0.2 & 0.4 \\
\hline Mean monthly temperature, resident spawning (Jun) & 0.0 & 0.1 & -0.0 & -0.3 & -0.5 & -0.1 & 0.0 & -0.3 & -0.6 & -0.6 & -0.3 & -0.1 & -0.1 & -0.1 & -0.6 & -0.4 & 0.5 & 0.3 & 0.5 \\
\hline Mean seasonal temperature, rearing and growth (Jul-Oct) & -0.0 & 0.0 & -0.0 & -0.7 & -0.8 & -0.3 & -0.2 & -0.0 & -0.8 & -0.8 & -0.0 & -0.0 & 0.0 & -0.2 & -0.7 & -0.4 & 0.5 & 0.3 & 0.5 \\
\hline
\end{tabular}


Table 7. Pearson's correlation coefficients of basin characteristics and climate characteristics in Connecticut.-Continued

[Red italics, basin characteristics used in regression equations; shaded, bold figures are correlations equal to or greater than 0.6]
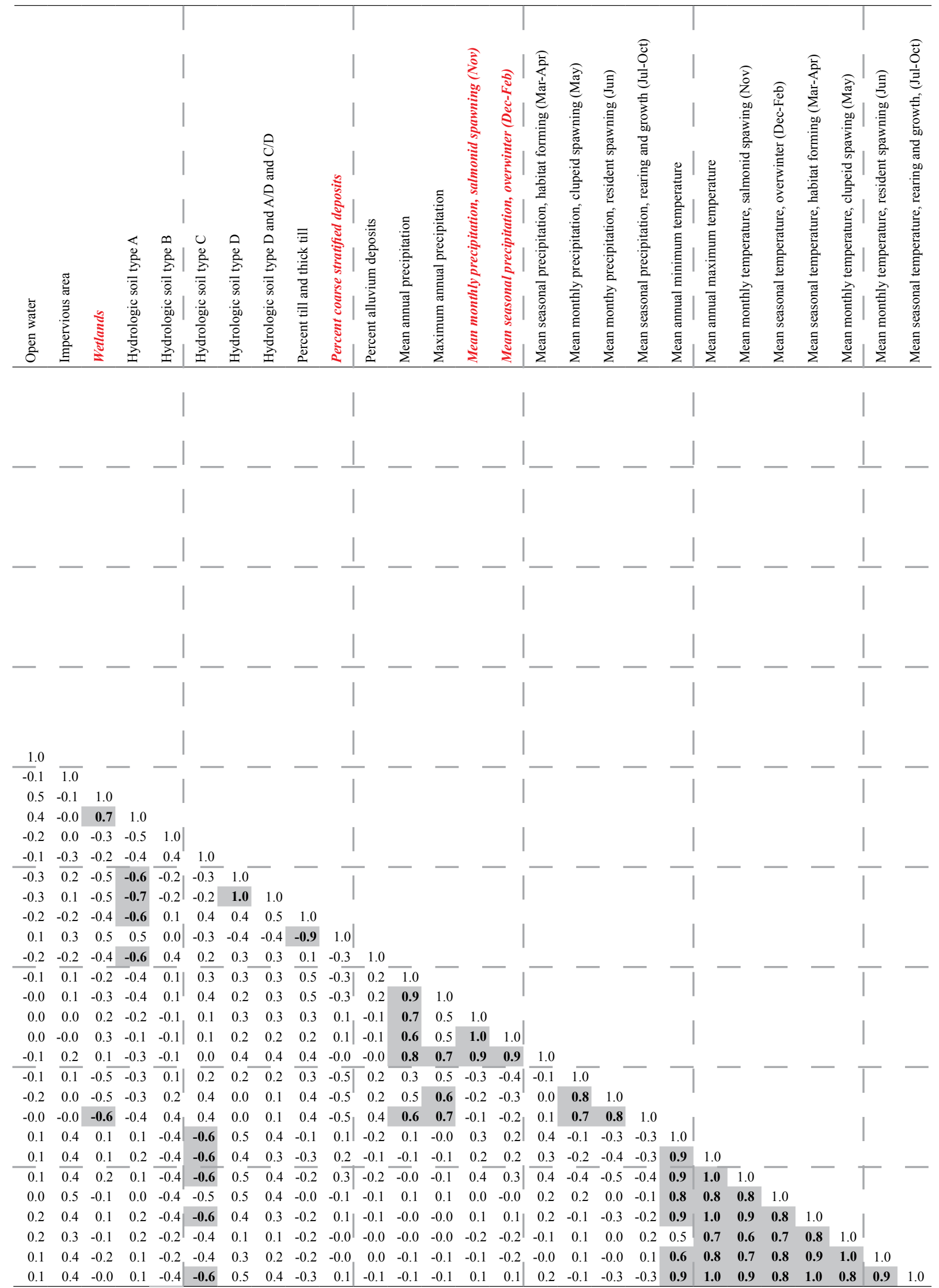
The equations with a smaller $\mathrm{SE}_{\mathrm{r}}$, Mallow's $\mathrm{Cp}$, and PRESS statistic and higher adj- $\mathrm{R}^{2}$ were preferred. In addition, the explanatory variables were selected based on (1) statistical significance at the 95-percent confidence level, (2) an analysis of the residuals, and (3) how the explanatory variables might affect flows. Explanatory variables that had a 95-percent probability of effectiveness (probably a good predictor of flow and not due to chance) were classified as significant. If an explanatory variable was significant but had only a small effect on the standard error (arbitrarily chosen as less than a 2-percent change), it was left out of the equation.

An additional criterion in selecting explanatory variables for the final regression equations was to have no more than three variables (basin characteristics). This was done to minimize overfitting the regression equation and to avoid multicollinearity among variables, which makes it difficult to evaluate the relative importance of the individual explanatory variable in the regression equation. Multicollinearity occurs when two (or more) explanatory variables are more highly correlated with each other than they are correlated with the predictor variable. The statistic used to measure the amount of multicollinearity is the variance-inflation factor (VIF) (Montgomery and others, 2001). VIF values express the ratio of the actual variance of the coefficient of the explanatory variable to its variance if it were independent of the explanatory variables (Cavalieri and others, 2000). A VIF value greater than 5-10 generally indicates that multicollinearity is a serious problem in the regression model. The basin characteristics with a VIF value less than five were chosen as the final set of explanatory variables to form the regression equations.

Ordinary least squares (OLS) and weighted least squares (WLS) regression were used for developing the equations and deriving the final coefficients in the equations (Helsel and Hirsch, 1992). In OLS regression, equal weight is given to all streamgages in the analysis regardless of record length. However, the records are not equally reliable; records from a streamgage with 10 years of flow data are not as reliable as records from a streamgage with 50 years of data. The WLS method assigns more weight in the regression to sites with longer records than shorter records, and thus, presumably, the equations are more accurate. In WLS regression, the userdefined weights were computed as the years of record at the streamgage divided by the average number of years (34.6) of record of all of the streamgages. For example, Pendleton Brook (USGS streamgage 01118300) with 49 years of record was assigned a weight of 1.42 (49/34.6), while Indian River (USGS streamgage 01195100) with 26 years of record (23 years less than Pendleton Brook) was assigned a weight of $0.75(26 / 34.6)$.

Short-term and partial-record sites were used in conjunction with continuous-record streamgages in developing the regression equation to estimate the non-bioperiod $\mathrm{Q}_{99}$ (table 8, fig. 2). Short-term and partial-record sites are considered less reliable than continuous-record streamgages but were used to increase the number of sites in the analysis. For WLS weighting, short-term and partial-record sites were assigned 0.5 year for each year in which measurements were made. The userdefined weights were based on the assumption that 1 year at a partial-record site is equal to 2 years at a continuous-record site. WLS regression was used to compute the final coefficients in all 32 regression equations.

\section{Assessment of Regression Equations}

Methods of assessing the adequacy of the equations included testing each one carefully for violations of the regression assumptions and problems with outliers. The basic assumptions for a regression equation include: (1) the equation adequately describes the relation between the response and explanatory variables, (2) the mean of the residual error is zero, (3) the variance of the residual error is constant, (4) the residual errors are normally distributed, and (5) the residual errors are independent of one another (Helsel and Hirsch, 1992). Examination of the residuals plots indicated no unusual patterns. Overall, the equations appeared to fit the data reasonably well and adequately described the relation between the response and explanatory variables. The $\mathrm{p}$-values from the WLS regression were checked for significance and found to be less than or equal to 0.05 , which indicates the probability that the regression coefficient is significant.

Diagnostic checks on the equations included evaluating outliers and influential observations. The presence of outliers is a subtle form of non-normality and influential observations are data that substantially change the fit of the regression line. The influence of an individual observation on the regressions is measured with Cook's D statistic (Helsel and Hirsch, 1992). Cook's D statistic is a measure of the change in the parameter estimates when an observation is deleted from the regression analysis. No influential observations were found with Cook's D statistic; therefore, no individual observation appreciably altered the slope of the regression line.

\section{Final Regression Equations}

Final regression equations are listed in table 9, along with the number of stations used in the regression analysis and several performance metrics. The StreamStats variable name and the explanatory variable name used in the final regression equations, along with a definition of the variable and the units of measure, are listed in appendix 2. Six basin characteristics - drainage area, percentage of area with coarse stratified deposits, percentage of the area with wetlands, mean monthly precipitation (November), mean seasonal precipitation (December, January, and February), and mean basin elevation - are used as explanatory variables in the equations. The explanatory variables in the equations were statistically significant at the 95-percent confidence level or better, were not correlated with other explanatory variables, and improved the standard errors by more than 2 percent. The performance metrics used to report the adequacy of the final regression equations included the adj- $\mathrm{R}^{2}$ in percent and the $\mathrm{SE}_{\mathrm{r}}$ in percent (described in "Development of Regression Equations"). The 


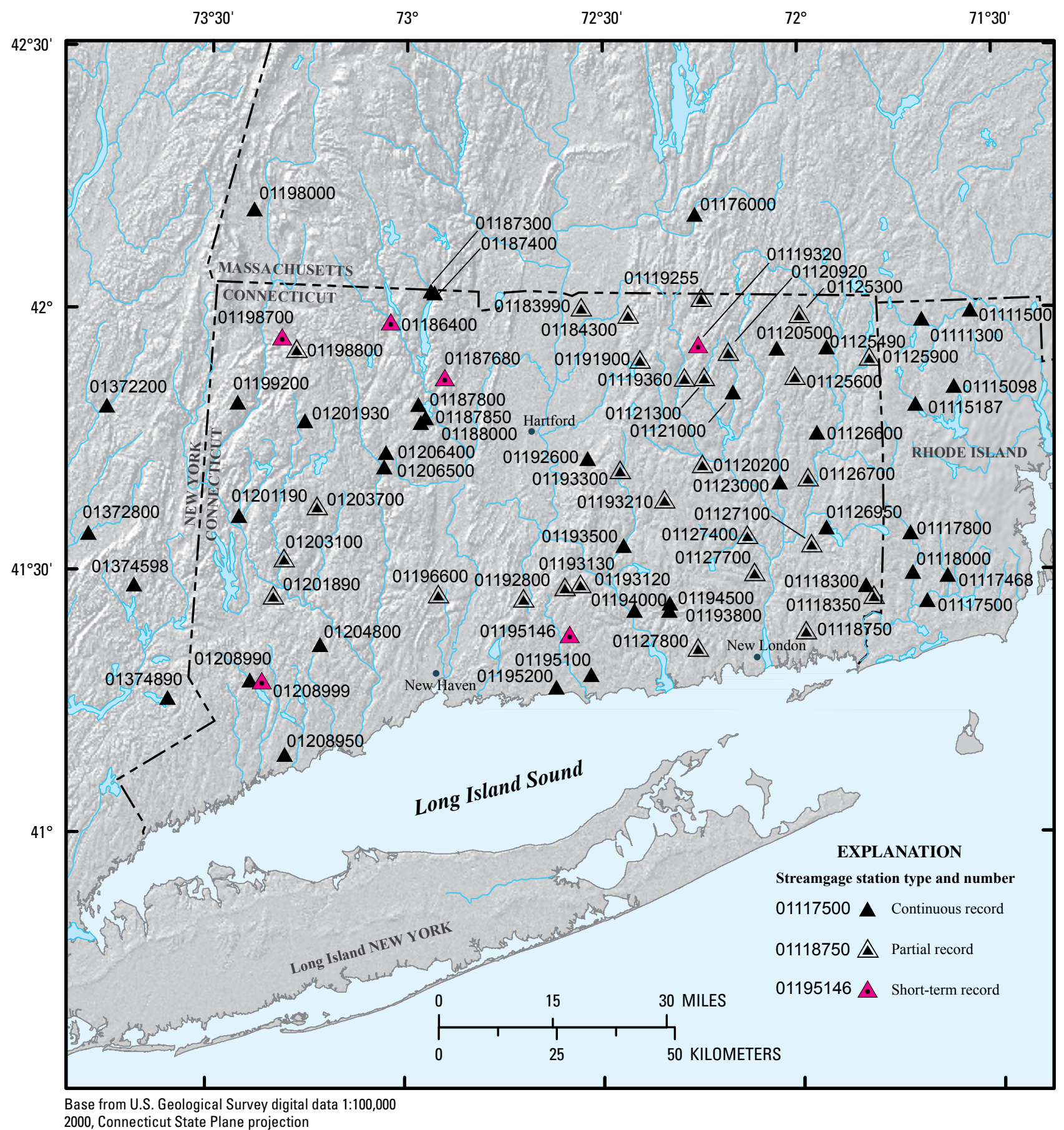

Figure 2. Locations of streamgages and short-term continuous-record and partial-record sites in Connecticut and surrounding states considered for use in developing a regression equation to estimate the non-bioperiod 99-percent flow exceedance $\left(0_{99}\right)$. 


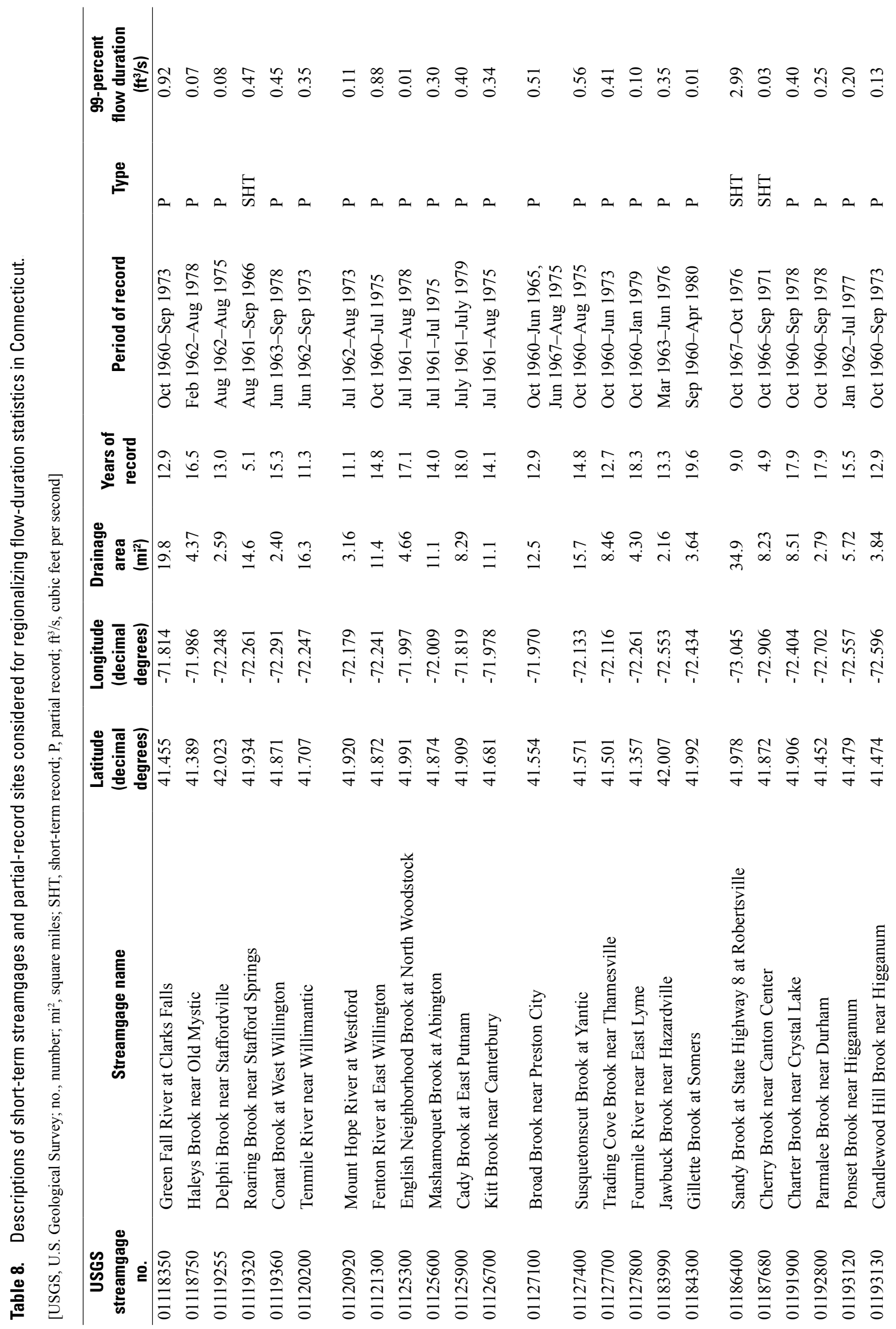




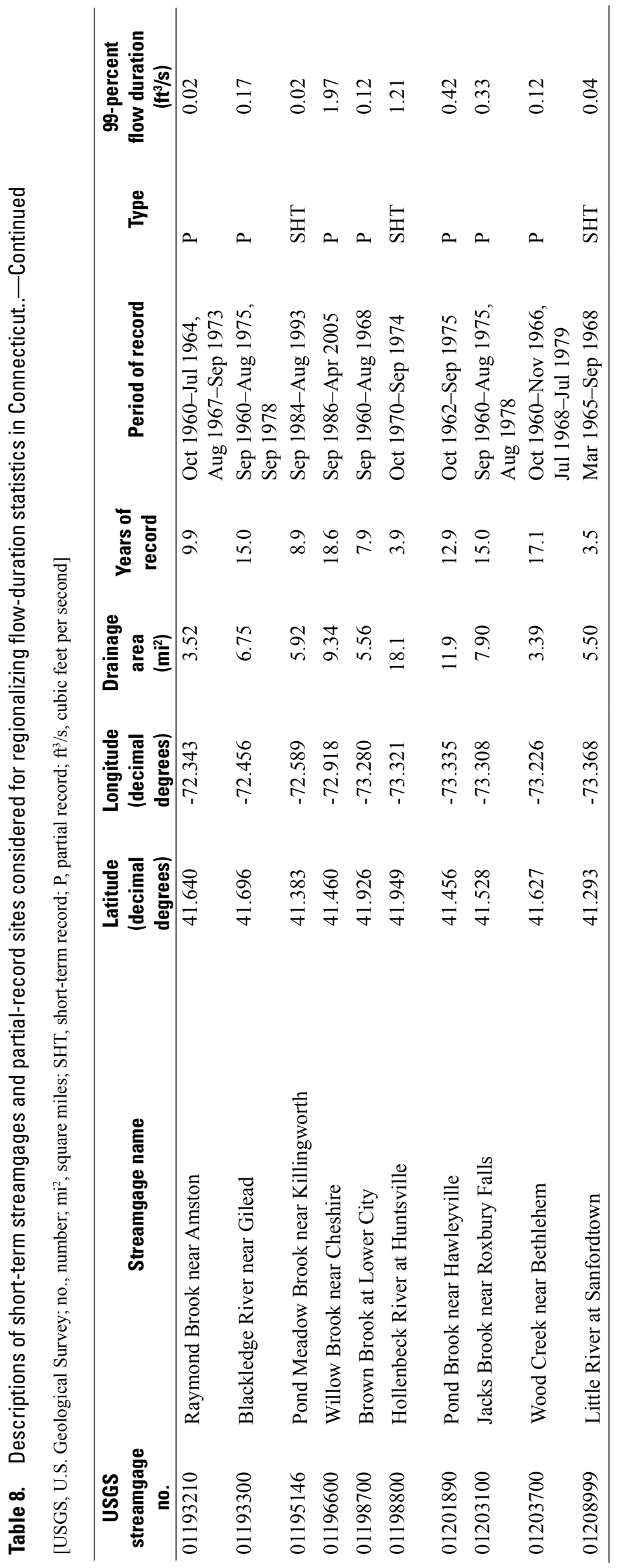


Table 9. Summary of regression equations for estimating flow-duration statistics at ungaged stream sites in Connecticut and performance metrics.

[adj- $\mathrm{R}^{2}$, adjusted coefficient of determination; $\mathrm{Q}_{25}, 25$-percent flow exceedance; $\mathrm{Q}_{50}, 50$-percent flow exceedance; $\mathrm{Q}_{75}, 75$-percent flow exceedance; $\mathrm{Q}_{80}, 80$-percent exceedance; $\mathrm{Q}_{90}, 90$-percent flow exceedance; $\mathrm{Q}_{95}, 95$-percent flow exceedance; $\mathrm{Q}_{99}$, 99-percent flow exceedance; DRNAREA, Drainage area, in square miles; PPTnov, mean monthly precipitation for November, in inches; CRSDFT, percentage of drainage area underlain with coarse stratified deposits; PPTow, mean seasonal precipitation for Dec-Feb, in inches; WETLAND, percentage of drainage area with wetlands; ELEV, mean basin elevation, in feet]

\begin{tabular}{|c|c|c|c|c|}
\hline & Regression equation & $\begin{array}{l}\text { Number } \\
\text { of } \\
\text { stations } \\
\text { used in } \\
\text { analysis }\end{array}$ & $\begin{array}{c}\text { adj-R2 } \\
\text { (percent) }\end{array}$ & $\begin{array}{l}\text { Average percent } \\
\text { standard error } \\
\text { of estimate } \\
\text { (range) }\end{array}$ \\
\hline \multirow{5}{*}{ 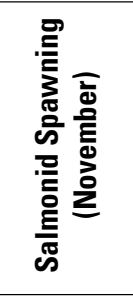 } & $\mathrm{Q}_{25}=\left(10^{-0.3513}\right)\left(\right.$ DRNAREA $\left.^{0.9813}\right)\left(\right.$ PPTnov $\left.^{1.0465}\right)$ & 39 & 98.5 & $20.9(23.0$ to -18.7$)$ \\
\hline & $\mathrm{Q}_{50}=\left(10^{-0.8383}\right)\left(\right.$ DRNAREA $\left.^{0.9761}\right)\left(\right.$ PPTnov $\left.^{1.3863}\right)$ & 39 & 98.2 & $21.1(23.2$ to -18.8$)$ \\
\hline & $\mathrm{Q}_{75}=\left(10^{-1.7042}\right)\left(\right.$ DRNAREA $\left.^{1.0175}\right)\left(\right.$ PPTnov $\left.^{2.1755}\right)$ & 39 & 96.4 & $27.4(30.9$ to -23.6$)$ \\
\hline & $\mathrm{Q}_{90}=\left(10^{-3.0117}\right)\left(\right.$ DRNAREA $\left.^{1.0418}\right)\left(\right.$ PPTnov $\left.^{3.5009}\right)\left(\right.$ CRSDFT $\left.^{0.1240}\right)$ & 39 & 95.8 & $36.0(41.8$ to -29.5$)$ \\
\hline & $\mathrm{Q}_{99}=\left(10^{-4.7478}\right)\left(\right.$ DRNAREA $\left.^{1.1056}\right)\left(\right.$ PPTnov $\left.^{5.2826}\right)\left(\right.$ CRSDFT $\left.^{0.2370}\right)$ & 39 & 90.6 & $55.4(67.8$ to -40.4$)$ \\
\hline \multirow{5}{*}{ 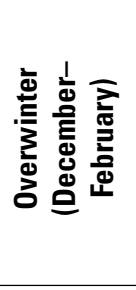 } & $\mathrm{Q}_{25}=\left(10^{-0.5449}\right)\left(\right.$ DRNAREA $\left.^{1.0092}\right)\left(\right.$ PPTow $\left.^{1.6126}\right)$ & 39 & 97.9 & $19.2(21.0$ to -17.4$)$ \\
\hline & $\mathrm{Q}_{50}=\left(10^{-0.9813}\right)\left(\right.$ DRNAREA $\left.^{1.0204}\right)\left(\right.$ PPTow $\left.^{1.9523}\right)$ & 39 & 97.4 & $21.4(23.6$ to -19.1$)$ \\
\hline & $\mathrm{Q}_{75}=\left(10^{-1.4090}\right)\left(\right.$ DRNAREA $\left.^{1.0328}\right)\left(\right.$ PPTow $\left.^{2.2826}\right)$ & 39 & 97.4 & 20.7 (22.7 to -18.5$)$ \\
\hline & $\mathrm{Q}_{95}=\left(10^{-2.0997}\right)\left(\right.$ DRNAREA $\left.^{1.0425}\right)\left(\right.$ PPTow $\left.^{2.8578}\right)$ & 39 & 96.4 & $24.9(27.8$ to -21.7$)$ \\
\hline & $\mathrm{Q}_{99}=\left(10^{-3.3438}\right)\left(\right.$ DRNAREA $\left.^{1.0733}\right)\left(\right.$ PPTow $\left.^{4.4479}\right)$ & 39 & 96.0 & $28.4(32.1$ to -24.3$)$ \\
\hline \multirow{5}{*}{ 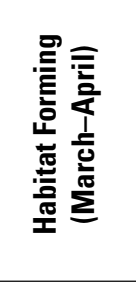 } & $\mathrm{Q}_{25}=\left(10^{0.6225}\right)\left(\right.$ DRNAREA $\left.^{1.0043}\right)$ & 39 & 99.4 & $11.1(11.7$ to -10.5$)$ \\
\hline & $\mathrm{Q}_{50}=\left(10^{0.4185}\right)\left(\right.$ DRNAREA $\left.^{1.0142}\right)$ & 39 & 99.4 & $10.7(11.2$ to -10.1$)$ \\
\hline & $\mathrm{Q}_{75}=\left(10^{0.1998}\right)\left(\right.$ DRNAREA $\left.^{1.0074}\right)\left(\right.$ CRSDFT $\left.^{0.0641}\right)$ & 39 & 99.3 & $12.9(13.7$ to -12.0$)$ \\
\hline & $\mathrm{Q}_{95}=\left(10^{-0.0583}\right)\left(\right.$ DRNAREA $\left.^{0.9998}\right)\left(\right.$ CRSDFT $\left.^{0.1007}\right)$ & 39 & 98.4 & $19.3(21.1$ to -17.4$)$ \\
\hline & $\mathrm{Q}_{99}=\left(10^{-0.2160}\right)\left(\right.$ DRNAREA $\left.^{0.9979}\right)\left(\right.$ CRSDFT $\left.^{0.1138}\right)$ & 39 & 98.0 & $20.9(22.9$ to -18.6$)$ \\
\hline \multirow{5}{*}{ 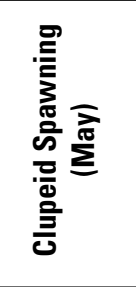 } & $\mathrm{Q}_{25}=\left(10^{0.4126}\right)\left(\right.$ DRNAREA $\left.^{0.9859}\right)\left(\right.$ CRSDFT $\left.^{0.0376}\right)$ & 39 & 99.0 & $15.1(16.2$ to -14.0$)$ \\
\hline & $\mathrm{Q}_{50}=\left(10^{0.1782}\right)\left(\right.$ DRNAREA $\left.^{0.9932}\right)\left(\right.$ CRSDFT $\left.^{0.0867}\right)$ & 39 & 98.8 & $17.2(18.6$ to -15.7$)$ \\
\hline & $\mathrm{Q}_{75}=\left(10^{-0.0217}\right)\left(\right.$ DRNAREA $\left.^{0.9959}\right)\left(\right.$ CRSDFT $\left.^{0.1207}\right)$ & 39 & 98.4 & $19.1(20.8$ to -17.2$)$ \\
\hline & $\mathrm{Q}_{95}=\left(10^{-0.3712}\right)\left(\right.$ DRNAREA $\left.^{1.0109}\right)\left(\right.$ CRSDFT $\left.^{0.1999}\right)$ & 39 & 96.9 & $28.1(31.7$ to -24.1$)$ \\
\hline & $\mathrm{Q}_{99}=\left(10^{-0.6137}\right)\left(\right.$ DRNAREA $\left.^{1.0322}\right)\left(\right.$ CRSDFT $\left.^{0.2525}\right)$ & 39 & 95.8 & $36.5(42.4$ to -29.8$)$ \\
\hline \multirow{5}{*}{ 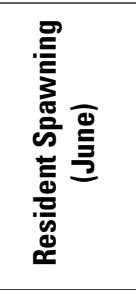 } & $\mathrm{Q}_{25}=\left(10^{0.1626}\right)\left(\right.$ DRNAREA $\left.^{0.9296}\right)\left(\right.$ CRSDFT $\left.^{0.0629}\right)\left(\right.$ WETLAND $\left.^{0.1276}\right)$ & 39 & 98.1 & $21.9(24.2$ to -19.5$)$ \\
\hline & $\mathrm{Q}_{50}=\left(10^{-0.1910}\right)\left(\right.$ DRNAREA $\left.^{0.9454}\right)\left(\right.$ CRSDFT $\left.^{0.1302}\right)\left(\right.$ WETLAND $\left.^{0.1242}\right)$ & 39 & 97.8 & $24.9(27.7$ to -21.7$)$ \\
\hline & $\mathrm{Q}_{75}=\left(10^{-0.5148}\right)\left(\right.$ DRNAREA $\left.^{0.9561}\right)\left(\right.$ CRSDFT $\left.^{0.1971}\right)\left(\right.$ WETLAND $\left.^{0.1518}\right)$ & 39 & 96.7 & $31.9(36.5$ to -26.7$)$ \\
\hline & $\mathrm{Q}_{90}=\left(10^{-0.8412}\right)\left(\right.$ DRNAREA $\left.^{1.0469}\right)\left(\right.$ CRSDFT $\left.^{0.2837}\right)$ & 39 & 94.5 & $40.5(47.7$ to -32.3$)$ \\
\hline & $\mathrm{Q}_{99}=\left(10^{-1.3044}\right)\left(\right.$ DRNAREA $\left.^{1.1021}\right)\left(\right.$ CRSDFT $\left.^{0.3671}\right)$ & 39 & 90.1 & $67.3(84.3$ to -45.7$)$ \\
\hline \multirow{5}{*}{ 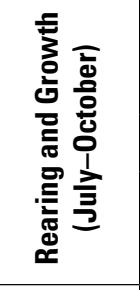 } & $\mathrm{Q}_{25}=\left(10^{-0.2991}\right)\left(\right.$ DRNAREA $\left.^{1.0311}\right)\left(\right.$ CRSDFT $\left.^{0.0962}\right)$ & 38 & 96.6 & $30.9(35.2$ to -26.0$)$ \\
\hline & $\mathrm{Q}_{50}=\left(10^{-0.7849}\right)\left(\right.$ DRNAREA $\left.^{1.0784}\right)\left(\right.$ CRSDFT $\left.^{0.1958}\right)$ & 38 & 94.5 & $40.7(47.9$ to -32.4$)$ \\
\hline & $\mathrm{Q}_{75}=\left(10^{-1.2209}\right)\left(\right.$ DRNAREA $\left.^{1.1328}\right)\left(\right.$ CRSDFT $\left.^{0.2765}\right)$ & 38 & 91.9 & $54.2(66.1$ to -39.8$)$ \\
\hline & $\mathrm{Q}_{80}=\left(10^{-1.3276}\right)\left(\right.$ DRNAREA $\left.^{1.1531}\right)\left(\right.$ CRSDFT $\left.^{0.2915}\right)$ & 38 & 90.9 & $59.2(72.9$ to -42.2$)$ \\
\hline & $\mathrm{Q}_{99}=\left(10^{-2.4534}\right)\left(\right.$ DRNAREA $\left.^{1.3776}\right)\left(\right.$ CRSDFT $\left.^{0.4798}\right)$ & 36 & 77.5 & $156(203$ to -67.0$)$ \\
\hline \multirow{2}{*}{ 흘흘 흘 } & $\mathrm{Q}_{25}=\left(10^{0.6903}\right)\left(\right.$ DRNAREA $\left.^{0.9976}\right)\left(\right.$ ELEV $\left.^{-0.1146}\right)$ & 39 & 99.2 & $14.5(15.5$ to -13.4$)$ \\
\hline & $\mathrm{Q}_{99}=\left(10^{-2.0567}\right)\left(\right.$ DRNAREA $\left.^{1.2141}\right)\left(\right.$ CRSDFT $\left.^{0.5037}\right)$ & 72 & 81.8 & $111(145$ to -59.1$)$ \\
\hline
\end{tabular}


metrics indicate how well the equations perform on the sites used in the regression analysis. Theoretically, the equations should perform equally well for ungaged sites as long as the basin characteristics are within the same range as those used to develop the equation. The $\mathrm{SE}_{\mathrm{r}}$ measures the difference between the observed value (flow derived from the streamgage record) and the predicted value (flow derived from the regression equation).

In general, the physical processes controlling high flows are related to drainage area and precipitation; the physical processes controlling low flows are related to geologic characteristics as well as drainage area. "Drainage area" was the predominant predictor in all the equations. "Precipitation" was an important predictor in two high-flow bioperiods: Salmonid Spawning (mean monthly precipitation for November) and Overwinter (mean seasonal precipitation for December through February). The inclusion of the precipitation characteristics in the regression models explained an additional 4.2 and 4.9 percent of the variability and improved the standard errors of estimate by 10.3 and 13.8 percent in the $\mathrm{Q}_{99}$ for the Salmonid Spawning and Overwinter bioperiods, respectively. The explanatory variable "percentage of area with coarse, stratified deposits" was an important predictor in all the bioperiods, with the exception of Overwinter (December-February); typically, this characteristic was important at the exceedances higher than $\mathrm{Q}_{75}$ (low-flow conditions). Drainage basins underlain with a large percent of coarse stratified deposits have larger base flows than drainage basins underlain with glacial till and bedrock (Thomas, 1966). The inclusion of the variable "percentage of area with coarse stratified deposits" in the equations explained an additional 4.7, 7.4, and 6.6 percent of the variability and improved the standard errors of estimate by 11.0, 15.6, and 19.0 percent in the $\mathrm{Q}_{99}$ for the Clupeid Spawning, Resident Spawning, and Rearing and Growth bioperiods, respectively. The explanatory variable "percentage of the area with wetlands" was a predictor of flows in the Resident Spawning bioperiod for the $\mathrm{Q}_{25}-\mathrm{Q}_{75}$ (June high and median flows). This explanatory variable, which showed a positive correlation to flow, may serve as an indicator for other factors such as soil-moisture content and surface storage that cause variation between basins but are difficult to evaluate. During wetter periods (spring), soils are saturated, and infiltration and surface storage are reduced. The explanatory variable "percentage of the area with wetlands" explained an additional 1 percent of the variability and improved the standard error of estimate by 4.4, 2.6, and 2.5 percent in the $\mathrm{Q}_{25}, \mathrm{Q}_{50}$, and $\mathrm{Q}_{75}$, respectively.

Where possible, the same explanatory variables were used for all flow exceedances in a bioperiod to ensure that the flow estimates decrease with an increase in the exceedance probability. For example, the $\mathrm{Q}_{99}$ is less than the $\mathrm{Q}_{90}$, and the $\mathrm{Q}_{90}$ is less than the $\mathrm{Q}_{75}$. In several bioperiods, an additional explanatory variable was added to the set of explanatory variables when it improved the standard error of estimate by more than 2 percent. The regression equations were checked to ensure that the flow estimates decrease with an increase in the exceedance probability in cases where an additional explanatory variable was added to the bioperiod.

The proportion of the variability in the flow statistic explained by the explanatory variable $\left(\operatorname{adj}-\mathrm{R}^{2}\right)$ was greater than 90 percent for all exceedances with two exceptions: equations explained only 77.5 percent of the variability in the $\mathrm{Q}_{99}$ for the Rearing and Growth bioperiod and 81.3 percent of the variability in the non-bioperiod $\mathrm{Q}_{99}$. The adj- $\mathrm{R}^{2}$ of the 32 regression equations ranged from 77.5 to 99.4 percent; the medians were 98.5 and 90.6 percent for the $\mathrm{Q}_{25}$ and $\mathrm{Q}_{99}$, respectively. Regression equations for high and median flows $\left(\mathrm{Q}_{25}, \mathrm{Q}_{50}\right.$, and $\left.\mathrm{Q}_{75}\right)$ generally had higher predictive power than regression equations for low flows $\left(\mathrm{Q}_{90}, \mathrm{Q}_{95}\right.$, and $\left.\mathrm{Q}_{99}\right)$. The standard errors of estimate to predict the $\mathrm{Q}_{25}$ and $\mathrm{Q}_{99}$ had medians of 19.2 and 55.4 percent, respectively. The Habitat Forming (March-April) bioperiod had the smallest standard errors of estimate, ranging from 10.7 to 20.9 percent for the $\mathrm{Q}_{50}$ and $\mathrm{Q}_{99}$, respectively. In contrast, the Rearing and Growth (July-Oct) bioperiod had the largest standard errors, ranging from 30.9 to 156 percent for the $\mathrm{Q}_{25}$ and $\mathrm{Q}_{99}$, respectively. Table 9 lists the range of standard errors, as well as the average, for each regression equation. In this study, the range is important when the average standard error is large. For example, for the $\mathrm{Q}_{99}$ in the Rearing and Growth bioperiod, the average standard error of estimate is 156 percent. If the regression equation resulted in a flow of $10 \mathrm{ft}^{3} / \mathrm{s}$, the range of flows could be between 3.3 and $30.3 \mathrm{ft}^{3} / \mathrm{s}$ based on the range of the standard error of estimate. Using the average of the standard error of estimate would give a range of flows between -5.6 and $25.6 \mathrm{ft}^{3} / \mathrm{s}$, which is not possible.

It is difficult to characterize low flows from information available in existing data sets. Subsequently, low flows typically have a large standard error of estimate. High evaporation rates, along with increased use of water by riparian vegetation, are processes that cause low flow but are difficult to capture as explanatory variables. The number of streamgages in the analysis, the number of years of record, the degree of the relation between the explanatory variable and the flow statistic, and the accuracy of the actual measurements all affect the accuracy of the estimates. Increasing any of these factors will improve the estimates. Future improvements in the regression equations for estimating flow durations, particularly low flows, may be made by evaluating different groupings of subsurface geologic characteristics and by incorporating higher spatial-resolution data as they become available.

\section{Limitation of the Regression Equations}

Statewide equations were developed because of the limited number of sites available for use in the regression analysis. An analysis of the residuals of the 32 regression equations indicated that no strong regional biases were evident. The residuals for each of the equations were plotted on a map. Several plots that include the variable "percentage of area with coarse stratified deposits" may show a slight regional bias. For example, figure 3 shows that the $\mathrm{Q}_{99}$ flows 


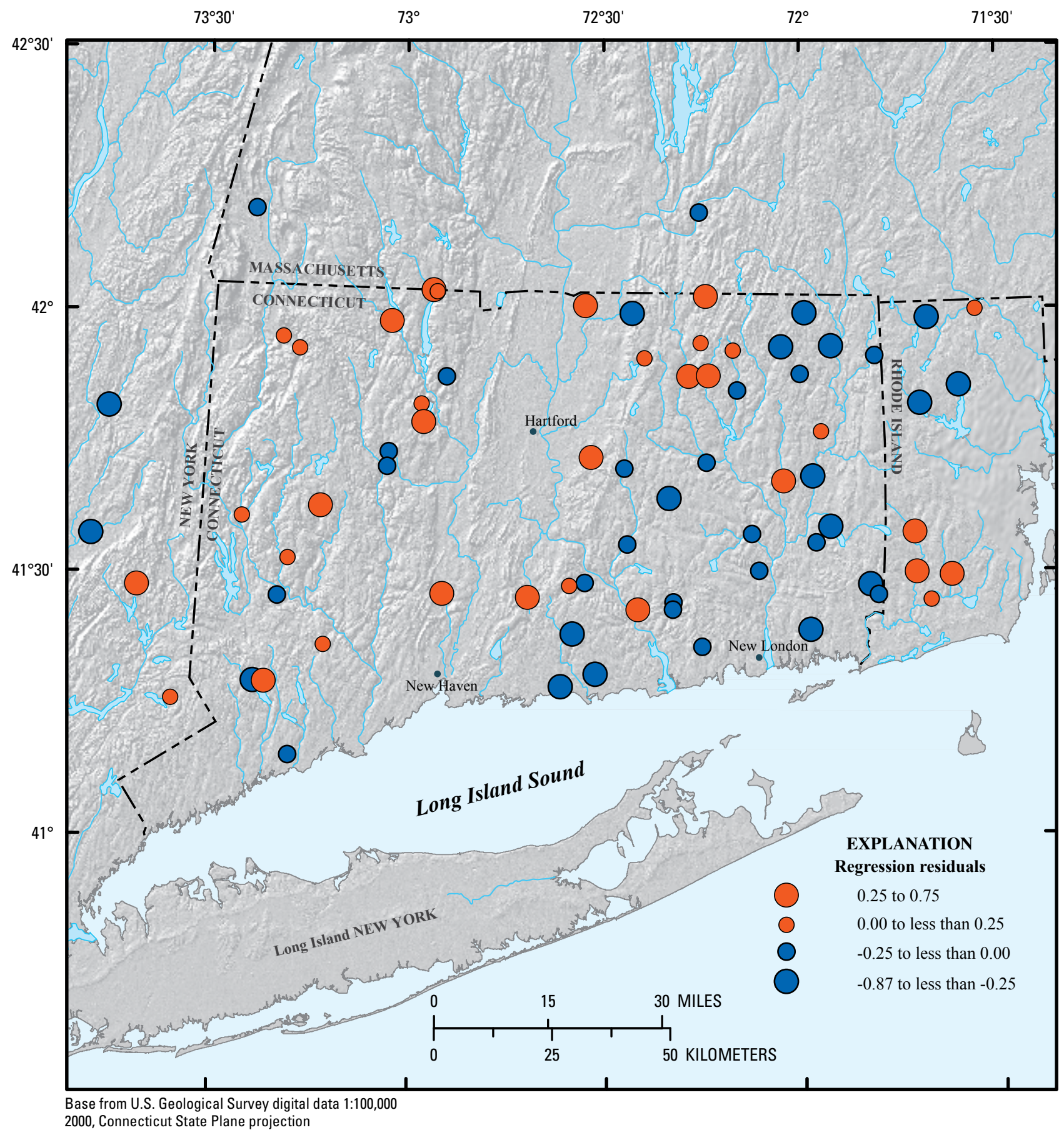

Figure 3. Residuals of the regression equation for the non-bioperiod 99-percent flow exceedance $\left(0_{99}\right)$ for the study area. Several stations considered as outliers or having a ${Q_{99}}_{9}$ value of zero were dropped from the non-bioperiod $\mathbf{C}_{99}$ regression analysis including Clear Brook (01187850), Marshepaug River (01201930), and Guinea Brook (01199200). 
in the eastern half of the State tend to be over-predicted and flows in the western half tend to be under-predicted. Regionalization of streamflow characteristics may be improved if there is an increased number of streamgages thus allowing for smaller subregions. The smaller subregions may provide a set of parameters with stronger predictive power. The regression equations developed in this study are not intended to be used at ungaged sites in which the basin characteristics are outside of the range of those used to create the regression equations (tables 5 and 6, at the back of this report). Flow statistics predicted by the equations represent natural flow conditions in Connecticut; effects of dams or other flow alterations are not included in the equations.

\section{Summary}

This report documents the development of regression equations with statewide application that can be used for determining flow-duration statistics at ungaged stream sites in Connecticut. Multiple linear regression equations using a weighted least squares (WLS) technique for determining flow-duration statistics were developed to estimate the 25-, 50-, 75- and 99-percent flow exceedances $\left(\mathrm{Q}_{25}, \mathrm{Q}_{50}, \mathrm{Q}_{75}\right.$, and $\mathrm{Q}_{99}$ ) for six bioperiods - Salmonid Spawning (November), Overwinter (December-February), Habitat Forming (MarchApril), Clupeid Spawning (May), Resident Spawning (June), and Rearing and Growth (July-October) - and one additional low-flow-duration statistic for each bioperiod - the 80-percent exceedance $\left(\mathrm{Q}_{80}\right)$ for the Rearing and Growth bioperiod; the 90-percent exceedance $\left(\mathrm{Q}_{90}\right)$ for the Resident Spawning and Salmonid Spawning bioperiods; and the 95-percent exceedance $\left(Q_{95}\right)$ for the Overwinter, Habitat Forming, and Clupeid Spawning bioperiods. Regression equations also were developed to estimate the 25- and 99-percent exceedances $\left(\mathrm{Q}_{25}\right.$ and $\mathrm{Q}_{99}$ ) without reference to a bioperiod.

Streamflow data and GIS-derived basin characteristics from 39 streamgages having 10 or more years of continuous record were used to develop the final equations. The equations were developed using WLS regression analyses with userdefined weights based on the years of streamflow record so that more weight was given in the regression models to sites with longer periods of record. Presumably, this would result in flow statistics that are more accurate. Flow exceedances computed from streamflow data through 2007 were statistically related to the basin characteristics upstream from the streamgages in the regression analysis. The basin characteristics - drainage area, percentage of area with coarse stratified deposits, percentage of the area with wetlands, monthly mean precipitation (November), mean seasonal precipitation (December-February), and mean basin elevation - were used as explanatory variables in the equations. These variables show a positive correlation to the flow for all exceedances.

The regression equations explain greater than 90 percent of the variability in the flow-duration statistics for all exceedances with two exceptions: 77.5 percent of the variability in the $\mathrm{Q}_{99}$ for the Rearing and Growth bioperiod and 81.3 percent of the variability in the $\mathrm{Q}_{99}$ for the long-term flow conditions. The standard errors of estimates for the 32 regression equations ranged from 10.7 to 156 percent. The Habitat Forming (March-April) bioperiod had the smallest standard errors of estimate, ranging from 10.7 to 20.9 percent for the $\mathrm{Q}_{50}$ and $\mathrm{Q}_{99}$, respectively. In contrast, the Rearing and Growth (July-October) bioperiod had the largest standard errors of estimate, ranging from 30.9 to 156 percent for the $\mathrm{Q}_{25}$ and $\mathrm{Q}_{99}$, respectively.

\section{Acknowledgments}

The author is most grateful for help from a number of colleagues. Christopher Bellucci and Mary Becker of DEP provided assistance with identifying study basins with natural flows. Julie Kiang from the USGS Office of Surface Water provided invaluable assistance with many parts of the regionalization study, particularly in the selection of the best models and performing the weighted least squares regression. David Lorenz from the USGS wrote scripts for calculating bioperiod statistics and provided invaluable assistance with interpreting the output of the regression models. Thomas Trombley and Lance Ostiguy (USGS) provided assistance with assembling the GIS data and compiling the drainage-basin characteristics. CT DEP and USGS colleague reviewers-Peter Aarrestad, Mary Becker, Christopher Bellucci, Corinne Fitting (all from DEP), and Julie Kiang, Scott Olson, and Marla Stuckey (all from USGS) - graciously provided thorough and timely reviews of the report. Finally, the author is also very grateful to Kim Otto and Virginia de Lima and for their exceptional editorial skills.

\section{References Cited}

Ahearn, E.A., 2004, Regression equations for estimating flood flows for the 2-, 10-, 25-, 50-, 100-, and 500-year recurrence intervals in Connecticut: U.S. Geological Survey Scientific Investigations Report 2004-5160, 62 p.

Ahearn, E.A., 2007, Flow durations, low-flow frequencies, and monthly median flows for selected streams in Connecticut through 2005: U.S. Geological Survey Scientific Investigations Report 2007-5270, $33 \mathrm{p}$.

Ahearn, E.A., Ries, K.G., III, and Steeves, P.A., 2006, StreamStats-U.S. Geological Survey web application for streamflow statistics in Connecticut: U.S. Geological Survey Fact Sheet 2006-3129, 4 p. 
Archfield, S.A., Vogel, R.M., Steeves, P.A., Brandt, S.L., Weiskel, P.W., and Garabedian, S.P., 2010, The Massachusetts Sustainable-Yield Estimator-A decision-support tool to assess water availability at ungaged stream locations in Massachusetts: U.S. Geological Survey Scientific Investigations Report 2009-5227, 41 p. plus CD-ROM.

Cavalieri, P., Jayawickrama, J., Luca, R., Patetta, M., Scott, K., and Walsh, S., 2000, Statistics I-Introduction to ANOVA, regression, and logistic regression: Cary, N.C., SAS Institute, Inc., $504 \mathrm{p}$.

Cervione, M.A., Jr., Mazzaferro, D.L., and Melvin, R.L., 1972, Water resources inventory of Connecticut, part 6, upper Housatonic River basin: Connecticut Water Resources Bulletin 21, 84 p.

Cervione, M.A., Jr., Melvin, R.L., and Cyr, K.A., 1982, A method for estimating the 7-day, 10-year low flow of streams in Connecticut: Connecticut Water Resources Bulletin $34,17 \mathrm{p}$.

Efroymson, M.A., 1960, Multiple regression analysis, in Ralston, A., and Wilf, H.S., eds., Mathematical methods for digital computers: New York, John Wiley and Sons, Inc., p. 191-203.

Handman, E.H., Haeni, F.P., and Thomas, M.P., 1986, Water resources inventory of Connecticut, part 9, Farmington River basin: Connecticut Water Resources Bulletin 29, $91 \mathrm{p}$.

Helsel, D.R., and Hirsch, R.M., 1992, Statistical methods in water resources: New York, Studies in Environmental Science 49, Elsevier Science Publishers, 529 p.

Mazzaferro, D.L., Handman, E.H., and Thomas, M.P., 1979, Water resources inventory of Connecticut, part 8, Quinnipiac River basin: Connecticut Water Resources Bulletin 27, $88 \mathrm{p}$.

Miller, D.R., Warner, G.S., Ogden, F.L., and DeGaetano, A.T., 2002, Precipitation in Connecticut: University of Connecticut Special Reports, Paper 36, 65 p.

Montgomery, D.C., Peck, E.A, and Vining, G.G., 2001, Introduction to linear regression analysis (3d ed.): New York, John Wiley \& Sons, Inc., 641 p.

Multi-Resolution Land Characteristics Consortium, 1992, National Land-Cover Dataset 1992: accessed on June 25, 2009, at http://www.mrlc.gov/mric2k_nlcd.asp.

Natural Resources Conservation Service, 2007, Soil Data Mart: U.S. Department of Agriculture, accessed on April 20, 2009, at http://soildatamart.nrcs.usda.gov.
Northeast Region Climate Center, 2009, Normal daily mean temperature: Ithaca, N.Y., Cornell University, accessed on June 25, 2009, at http://www.nrcc.cornell.edu/ccd/nrmavg.html.

Poff, N.L., Allan, J.D., Bain, M.B., Karr, J.R., Prestegaard, K.L., Richter, B.D., Sparks, R.E., and Stromberg, J.C., 1997, The natural flow regime-A new paradigm for riverine conservation and restoration: BioScience, v. 47, p. 769-784.

Randall, A.D., Thomas, M.P., Thomas, C.E., Jr., and Baker, J.A., 1966, Water resources inventory of Connecticut, part 1, Quinebaug River basin: Connecticut Water Resources Bulletin 8, $102 \mathrm{p}$.

Ries, K.G., III, and Friesz, P.J., 2000, Methods for estimating low-flow statistics for Massachusetts streams: U.S. Geological Survey Water-Resources Investigations Report 2000-4135, $81 \mathrm{p}$.

Ryder, R.B., Cervione, M.A., Jr., Thomas, C.E., Jr., and Thomas, M.P., 1970, Water resources inventory of Connecticut, part 4, southwestern coastal river basins: Connecticut Water Resources Bulletin 17, 54 p.

Ryder, R.B., Thomas, M.P., and Weiss, L.A., 1981, Water resources inventory of Connecticut, part 7, upper Connecticut River basin: Connecticut Water Resources Bulletin 24, $78 \mathrm{p}$.

Smith, Mark, 2009, Finding common ground-How advocacy coalitions succeed in protecting environmental flows: American Water Resources Association, v. 45, no. 5, p. 1100-1115.

State of Connecticut, 2009, Amendment to the Regulations of Connecticut State Agencies, section 26-141b-2. Definitions: accessed on January 12, 2010, at http://www.ct.gov/dep/lib/ dep/water/watershed_management/flowstandards/ proposedstreamflowstandardsregulations_2009oct13.pdf.

Stone, J.R., Schafer, J.P., London, E.H., and Thompson, W.B., 1992, Surficial materials map of Connecticut: U.S. Geological Survey Special Map, 2 sheets, scale 1:125,000.

Thomas, C.E., Jr., Cervione, M.A., Jr., and Grossman, I.G., 1968, Water resources inventory of Connecticut, part 3, lower Thames and southeastern coastal river basins: Connecticut Water Resources Bulletin 15, 105 p.

Thomas, D.M., and Benson, M.A., 1970, Generalization of streamflow characteristics from drainage-basin characteristics: U.S. Geological Survey Water-Supply Paper 1975, $55 \mathrm{p}$.

Thomas, M.P., 1966, Effect of glacial geology upon the time distribution of streamflow in eastern and southern Connecticut: U.S. Geological Survey Professional Paper 550-B, p. B209-B212. 
Thomas, M.P., Bednar, G.A., Thomas, C.E., Jr., and Wilson, W.E., 1967, Water resources inventory of Connecticut, part 2, Shetucket River basin: Connecticut Water Resources Bulletin 11, 96 p.

TIBCO Software Inc., 2008, TIBCO Spotfire $\mathrm{S}^{{ }^{\circledR}}{ }^{8} .1$ Guide to Packages: Palo Alto, Calif., 77 p.

U.S. Geological Survey, 2006, National Elevation Dataset: accessed on June 25,2009 , at http://ned.usgs.gov.

Vogel, R.M., and Stedinger, J.R., 1985, Minimum variance streamflow record augmentation procedures: Water Resources Research, v. 21, no. 5, p. 715-723.

Weiss, L.A., 1983, Evaluation and design of a streamflow data network for Connecticut: Connecticut Water Resources Bulletin 36, $30 \mathrm{p}$.

Weiss, L.A., Bingham, J.W., and Thomas, M.P., 1982, Water resources inventory of Connecticut, part 10, lower Connecticut River basin: Connecticut Water Resources Bulletin $31,85 \mathrm{p}$.

Wilson, W.E., Burke, E.L., and Thomas, C.E., Jr., 1974, Water resources inventory of Connecticut, part 5, lower Housatonic River basin: Connecticut Water Resources Bulletin $19,79 \mathrm{p}$. 
Table 3. Flow-duration statistics for streamgages with at least 10 years of continuous record in Connecticut and neighboring states considered for regression analysis: $A$, Actual streamflow; $B$, Normalized streamflow.

[USGS, U.S. Geological Survey; no. number; $\mathrm{mi}^{2}$, square miles; $\mathrm{Q}_{25}$, 25-percent flow exceedance; $\mathrm{Q}_{50}$, 50-percent flow exceedance; $\mathrm{Q}_{75}, 75$-percent flow exceedance; $\mathrm{Q}_{90}, 90$-percent flow exceedance; $\mathrm{Q}_{99}, 99$-percent flow exceedance]

\begin{tabular}{|c|c|c|c|c|c|}
\hline \multicolumn{6}{|c|}{ A. Actual streamflow, in cubic feet per second } \\
\hline \multirow{2}{*}{$\begin{array}{c}\text { USGS } \\
\text { streamgage no. }\end{array}$} & \multirow{2}{*}{ Streamgage name } & \multirow{2}{*}{ State } & \multirow{2}{*}{$\begin{array}{l}\text { Drainage area } \\
\qquad\left(\mathrm{mi}^{2}\right)\end{array}$} & \multicolumn{2}{|c|}{ Non-bioperiod } \\
\hline & & & & $\mathbf{O}_{25}$ & $\mathbf{Q}_{99}$ \\
\hline 01111300 & Nipmuc River near Harrisville & Rhode Island & 16.0 & 39.0 & 0.34 \\
\hline 01111500 & Branch River at Forestdale & Rhode Island & 91.2 & 228 & 13.0 \\
\hline 01115098 & Peeptoad Brook at Elmdale Road near Westerly & Rhode Island & 4.83 & 14.0 & 0.09 \\
\hline 01115187 & Ponaganset River at South Foster & Rhode Island & 14.4 & 35.0 & 0.11 \\
\hline 01117468 & Beaver River near Usquepaug & Rhode Island & 8.87 & 30.0 & 2.09 \\
\hline 01117500 & Pawcatuck River at Wood River Junction & Rhode Island & 100 & 266 & 28.0 \\
\hline 01117800 & Wood River near Arcadia & Rhode Island & 35.2 & 103 & 7.70 \\
\hline 01118000 & Wood River at Hope Valley & Rhode Island & 72.4 & 210 & 19.0 \\
\hline 01118300 & Pendleton Hill Brook near Clarks Falls & Connecticut & 4.02 & 11.0 & 0.06 \\
\hline 01120500 & Safford Brook near Woodstock Valley & Connecticut & 4.15 & 8.50 & 0.02 \\
\hline 01121000 & Mount Hope River near Warrenville & Connecticut & 28.6 & 66.0 & 1.00 \\
\hline 01123000 & Little River near Hanover & Connecticut & 30.0 & 69.0 & 4.90 \\
\hline 01125490 & Little River at Harrisville & Connecticut & 35.8 & 56.0 & 0.60 \\
\hline 01126600 & Blackwell Brook near Brooklyn & Connecticut & 17.0 & 38.0 & 0.70 \\
\hline 01126950 & Pachaug River at Pachaug & Connecticut & 53.0 & 130 & 0.76 \\
\hline 01176000 & Quaboag River at West Brimfield & Massachusetts & 150 & 344 & 16.0 \\
\hline 01187300 & Hubbard Brook near West Hartland & Connecticut & 19.9 & 43.0 & 0.56 \\
\hline 01187400 & Valley Brook near West Hartland & Connecticut & 7.03 & 16.0 & 0.30 \\
\hline 01187800 & Nepaug River near Nepaug & Connecticut & 23.5 & 46.0 & 1.50 \\
\hline 01187850 & Clear Brook near Collinsville $^{1}$ & Connecticut & 0.59 & 2.1 & 0.53 \\
\hline 01188000 & Bunnell Brook near Burlington & Connecticut & 4.10 & 9.30 & 0.65 \\
\hline 01192600 & South Branch Salmon Brook at Buckingham & Connecticut & 0.94 & 2.00 & 0.31 \\
\hline 01193500 & Salmon River near East Hampton & Connecticut & 100 & 238 & 6.40 \\
\hline 01193800 & Hemlock Valley Brook at Hadlyme & Connecticut & 2.62 & 6.90 & 0.20 \\
\hline 01194000 & Eightmile River at North Plain & Connecticut & 20.1 & 50.0 & 0.60 \\
\hline 01194500 & East Branch Eightmile River near North Lyme & Connecticut & 22.3 & 58.0 & 0.63 \\
\hline 01195100 & Indian River near Clinton & Connecticut & 5.68 & 13.0 & 0.08 \\
\hline 01195200 & Neck River near Madison & Connecticut & 6.55 & 15.0 & 0.06 \\
\hline 01198000 & Green River near Great Barrington & Massachusetts & 51.0 & 102 & 3.30 \\
\hline 01199200 & Guinea Brook at West Woods Road at Ellsworth & Connecticut & 3.50 & 9.20 & ${ }^{2} 0.00$ \\
\hline 01201190 & West Aspectuck River at Sand Road near New Milford & Connecticut & 23.8 & 44.0 & 0.95 \\
\hline 01201930 & Marshepaug River near Milton1 & Connecticut & 9.24 & 27.0 & 0.45 \\
\hline 01204800 & Copper Mill Brook near Monroe & Connecticut & 2.45 & 5.70 & 0.10 \\
\hline 01206400 & Leadmine Brook near Harwinton & Connecticut & 19.6 & 45.0 & 0.60 \\
\hline 01206500 & Leadmine Brook near Thomaston & Connecticut & 24.3 & 56.0 & 0.60 \\
\hline 01208950 & Sasco Brook near Southport & Connecticut & 7.38 & 16.0 & 0.09 \\
\hline 01208990 & Saugatuck River near Redding & Connecticut & 21.0 & 51.0 & 0.35 \\
\hline 01372200 & Wappinger Creek near Clinton Corners & New York & 92.4 & 160 & 4.10 \\
\hline 01372800 & Fishkill Creek at Hopewell Junction & New York & 57.2 & 105 & 2.00 \\
\hline 01374598 & Horse Pound Brook near Lake Carmel & New York & 3.94 & 10.0 & 0.04 \\
\hline 01374890 & Cross River near Cross River & New York & 17.1 & 44.0 & 0.46 \\
\hline
\end{tabular}

${ }^{1}$ Site not used in regression.

${ }^{2}$ Zero value not used in regression. 
Table 3. Flow-duration statistics for streamgages with at least 10 years of continuous record in Connecticut and neighboring states considered for regression analysis: $A$, Actual streamflow; $B$, Normalized streamflow.-Continued

[USGS, U.S. Geological Survey; no. number; $\mathrm{mi}^{2}$, square miles; $\mathrm{Q}_{25}$, 25-percent flow exceedance; $\mathrm{Q}_{50}, 50$-percent flow exceedance; $\mathrm{Q}_{75}, 75$-percent flow exceedance; $\mathrm{Q}_{90}, 90$-percent flow exceedance; $\mathrm{Q}_{99}, 99$-percent flow exceedance]

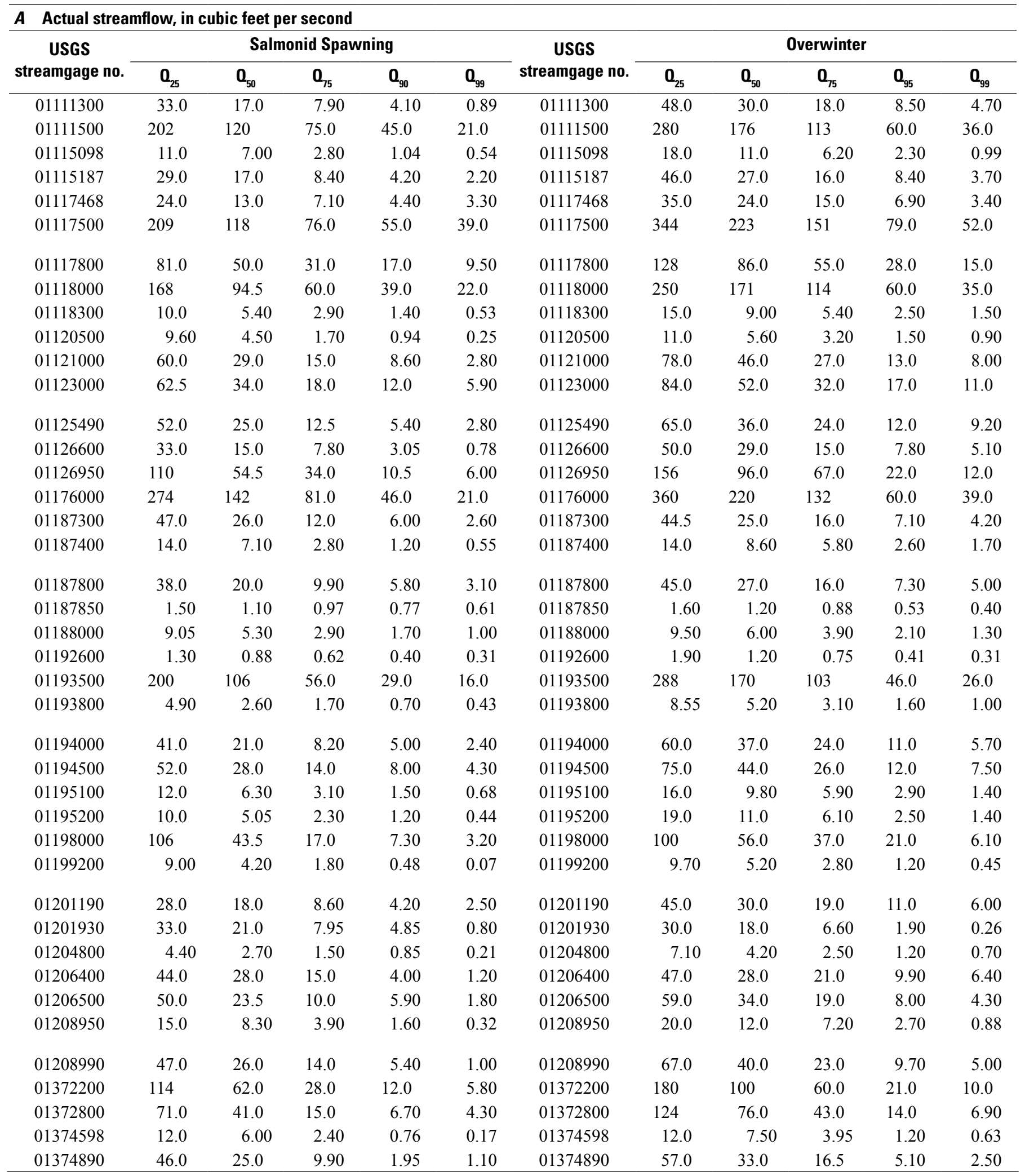


Table 3. Flow-duration statistics for streamgages with at least 10 years of continuous record in Connecticut and neighboring states considered for regression analysis: $A$, Actual streamflow; $B$, Normalized streamflow.-Continued

[USGS, U.S. Geological Survey; no. number; $\mathrm{mi}^{2}$, square miles; $\mathrm{Q}_{25}, 25$-percent flow exceedance; $\mathrm{Q}_{50}, 50$-percent flow exceedance; $\mathrm{Q}_{75}, 75$-percent flow exceedance; $\mathrm{Q}_{90}, 90$-percent flow exceedance; $\mathrm{Q}_{99}, 99$-percent flow exceedance]

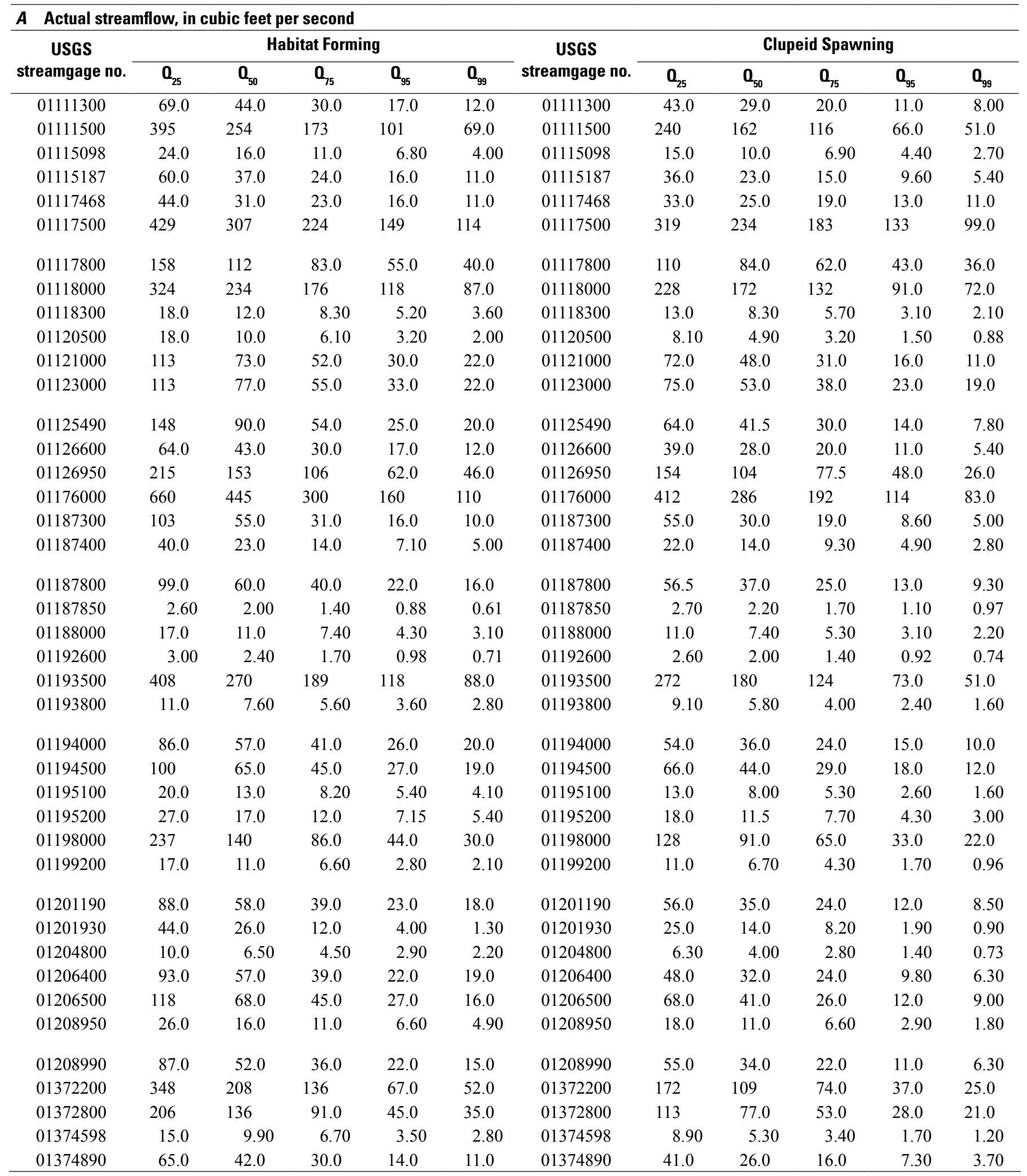


Table 3. Flow-duration statistics for streamgages with at least 10 years of continuous record in Connecticut and neighboring states considered for regression analysis: $A$, Actual streamflow; $B$, Normalized streamflow.-Continued

[USGS, U.S. Geological Survey; no. number; $\mathrm{mi}^{2}$, square miles; $\mathrm{Q}_{25}, 25$-percent flow exceedance; $\mathrm{Q}_{50}$, 50-percent flow exceedance; $\mathrm{Q}_{75}$, 75-percent flow exceedance; $\mathrm{Q}_{90}, 90$-percent flow exceedance; $\mathrm{Q}_{99}, 99$-percent flow exceedance]

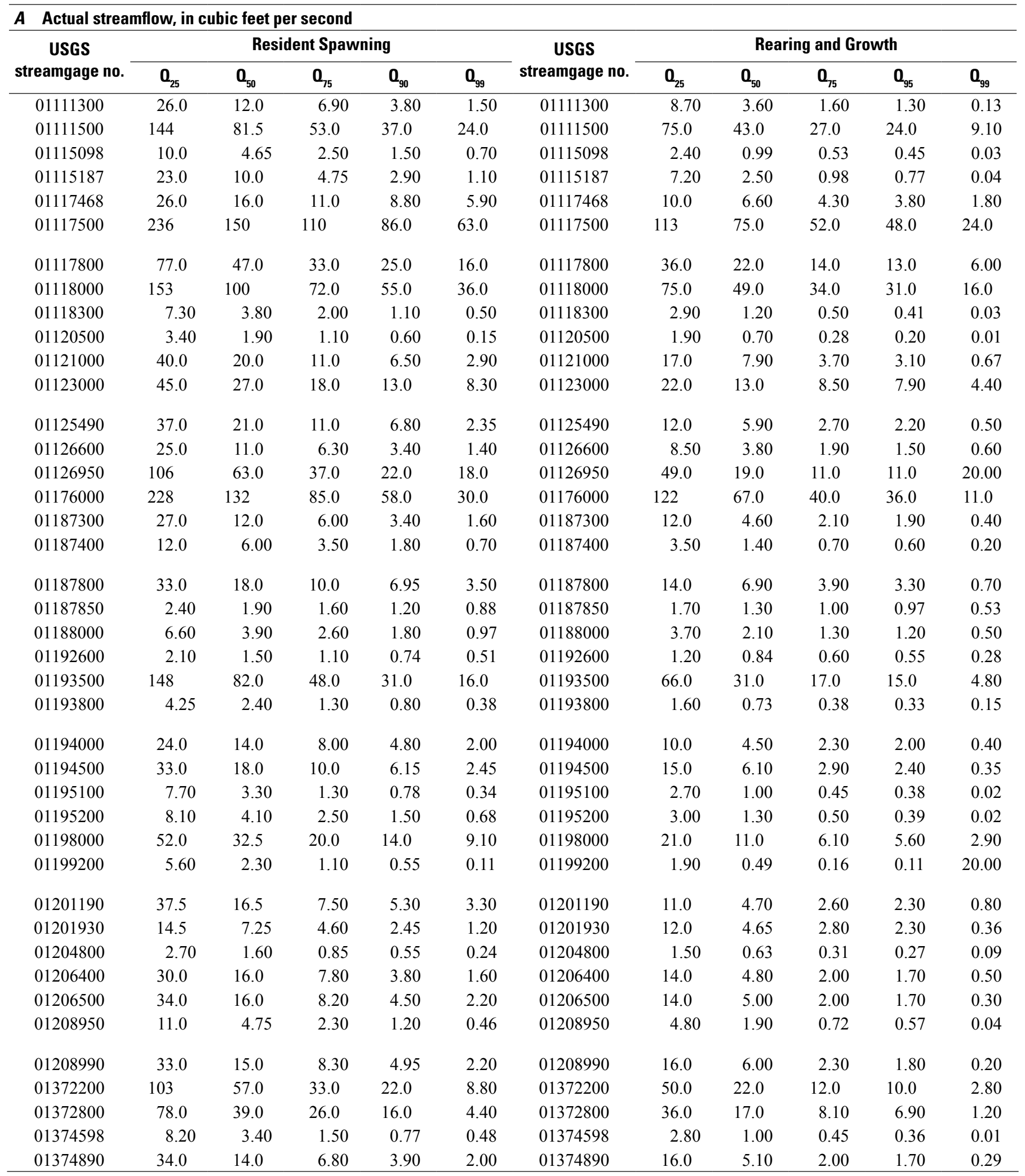


Table 3. Flow-duration statistics for streamgages with at least 10 years of continuous record in Connecticut and neighboring states considered for regression analysis: $A$, Actual streamflow; $B$, Normalized streamflow.-Continued

[USGS, U.S. Geological Survey; no. number; $\mathrm{mi}^{2}$, square miles; $\mathrm{Q}_{25}, 25$-percent flow exceedance; $\mathrm{Q}_{50}$, 50-percent flow exceedance; $\mathrm{Q}_{75}, 75$-percent flow exceedance; $\mathrm{Q}_{90}, 90$-percent flow exceedance; $\mathrm{Q}_{99}, 99$-percent flow exceedance]

\begin{tabular}{|c|c|c|c|c|c|}
\hline \multicolumn{6}{|c|}{ B Normalized streamflow, in cubic feet per second per square mile } \\
\hline \multirow{2}{*}{$\begin{array}{c}\text { USGS } \\
\text { streamgage no. }\end{array}$} & \multirow{2}{*}{ Streamgage name } & \multirow{2}{*}{ State } & \multirow{2}{*}{$\begin{array}{l}\text { Drainage area } \\
\qquad\left(\mathrm{mi}^{2}\right)\end{array}$} & \multicolumn{2}{|c|}{ Non-bioperiod } \\
\hline & & & & $\mathbf{O}_{25}$ & $\mathbf{O}_{99}$ \\
\hline 01111300 & Nipmuc River near Harrisville & Rhode Island & 16.0 & 2.44 & 0.02 \\
\hline 01111500 & Branch River at Forestdale & Rhode Island & 91.2 & 2.50 & 0.14 \\
\hline 01115098 & Peeptoad Brook at Elmdale Road near Westerly & Rhode Island & 4.83 & 2.90 & 0.02 \\
\hline 01115187 & Ponaganset River at South Foster & Rhode Island & 14.4 & 2.43 & 0.01 \\
\hline 01117468 & Beaver River near Usquepaug & Rhode Island & 8.87 & 3.38 & 0.24 \\
\hline 01117500 & Pawcatuck River at Wood River Junction & Rhode Island & 100 & 2.66 & 0.28 \\
\hline 01117800 & Wood River near Arcadia & Rhode Island & 35.2 & 2.93 & 0.22 \\
\hline 01118000 & Wood River at Hope Valley & Rhode Island & 72.4 & 2.90 & 0.26 \\
\hline 01118300 & Pendleton Hill Brook near Clarks Falls & Connecticut & 4.02 & 2.74 & 0.01 \\
\hline 01120500 & Safford Brook near Woodstock Valley & Connecticut & 4.15 & 2.05 & 0.00 \\
\hline 01121000 & Mount Hope River near Warrenville & Connecticut & 28.6 & 2.31 & 0.03 \\
\hline 01123000 & Little River near Hanover & Connecticut & 30.0 & 2.30 & 0.16 \\
\hline 01125490 & Little River at Harrisville & Connecticut & 35.8 & 1.56 & 0.02 \\
\hline 01126600 & Blackwell Brook near Brooklyn & Connecticut & 17.0 & 2.24 & 0.04 \\
\hline 01126950 & Pachaug River at Pachaug & Connecticut & 53.0 & 2.45 & 0.01 \\
\hline 01176000 & Quaboag River at West Brimfield & Massachusetts & 150 & 2.29 & 0.11 \\
\hline 01187300 & Hubbard Brook near West Hartland & Connecticut & 19.9 & 2.16 & 0.03 \\
\hline 01187400 & Valley Brook near West Hartland & Connecticut & 7.03 & 2.28 & 0.04 \\
\hline 01187800 & Nepaug River near Nepaug & Connecticut & 23.5 & 1.96 & 0.06 \\
\hline 01187850 & Clear Brook near Collinsville1 & Connecticut & 0.59 & 3.56 & 0.90 \\
\hline 01188000 & Bunnell Brook near Burlington & Connecticut & 4.10 & 2.27 & 0.16 \\
\hline 01192600 & South Branch Salmon Brook at Buckingham & Connecticut & 0.94 & 2.13 & 0.33 \\
\hline 01193500 & Salmon River near East Hampton & Connecticut & 100 & 2.38 & 0.06 \\
\hline 01193800 & Hemlock Valley Brook at Hadlyme & Connecticut & 2.62 & 2.63 & 0.08 \\
\hline 01194000 & Eightmile River at North Plain & Connecticut & 20.1 & 2.49 & 0.03 \\
\hline 01194500 & East Branch Eightmile River near North Lyme & Connecticut & 22.3 & 2.60 & 0.03 \\
\hline 01195100 & Indian River near Clinton & Connecticut & 5.68 & 2.29 & 0.01 \\
\hline 01195200 & Neck River near Madison & Connecticut & 6.55 & 2.29 & 0.01 \\
\hline 01198000 & Green River near Great Barrington & Massachusetts & 51.0 & 2.00 & 0.06 \\
\hline 01199200 & Guinea Brook at West Woods Road at Ellsworth & Connecticut & 3.50 & 2.63 & 0.00 \\
\hline 01201190 & West Aspectuck River at Sand Road near New Milford & Connecticut & 23.8 & 1.85 & 0.04 \\
\hline 01201930 & Marshepaug River near Milton1 & Connecticut & 9.24 & 2.92 & 0.05 \\
\hline 01204800 & Copper Mill Brook near Monroe & Connecticut & 2.45 & 2.33 & 0.04 \\
\hline 01206400 & Leadmine Brook near Harwinton & Connecticut & 19.6 & 2.30 & 0.03 \\
\hline 01206500 & Leadmine Brook near Thomaston & Connecticut & 24.3 & 2.30 & 0.02 \\
\hline 01208950 & Sasco Brook near Southport & Connecticut & 7.38 & 2.17 & 0.01 \\
\hline 01208990 & Saugatuck River near Redding & Connecticut & 21.0 & 2.43 & 0.02 \\
\hline 01372200 & Wappinger Creek near Clinton Corners & New York & 92.4 & 1.73 & 0.04 \\
\hline 01372800 & Fishkill Creek at Hopewell Junction & New York & 57.2 & 1.84 & 0.03 \\
\hline 01374598 & Horse Pound Brook near Lake Carmel & New York & 3.94 & 2.54 & 0.01 \\
\hline \multirow[t]{4}{*}{01374890} & Cross River near Cross River & New York & 17.1 & 2.57 & 0.03 \\
\hline & & & Minimum & 1.56 & 0.00 \\
\hline & & & Maximum & 3.56 & 0.90 \\
\hline & & & Average & 2.41 & 0.09 \\
\hline
\end{tabular}


Table 3. Flow-duration statistics for streamgages with at least 10 years of continuous record in Connecticut and neighboring states considered for regression analysis: $A$, Actual streamflow; $B$, Normalized streamflow.-Continued

[USGS, U.S. Geological Survey; no. number; $\mathrm{mi}^{2}$, square miles; $\mathrm{Q}_{25}, 25$-percent flow exceedance; $\mathrm{Q}_{50}, 50$-percent flow exceedance; $\mathrm{Q}_{75}, 75$-percent flow exceedance; $\mathrm{Q}_{90}, 90$-percent flow exceedance; $\mathrm{Q}_{99}, 99$-percent flow exceedance]

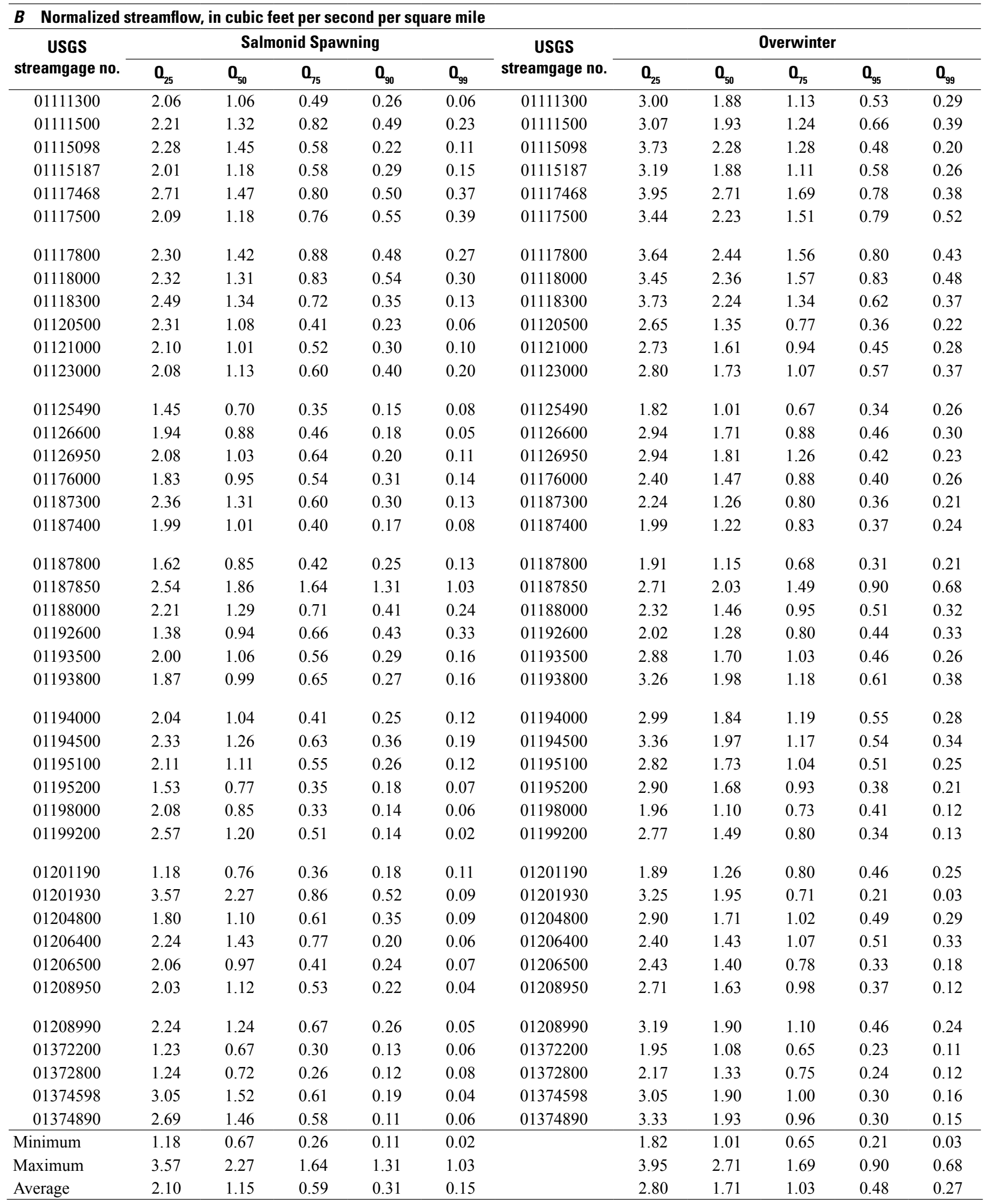


Table 3. Flow-duration statistics for streamgages with at least 10 years of continuous record in Connecticut and neighboring states considered for regression analysis: $A$, Actual streamflow; $B$, Normalized streamflow.-Continued

[USGS, U.S. Geological Survey; no. number; $\mathrm{mi}^{2}$, square miles; $\mathrm{Q}_{25}, 25$-percent flow exceedance; $\mathrm{Q}_{50}, 50$-percent flow exceedance; $\mathrm{Q}_{75}, 75$-percent flow exceedance; $\mathrm{Q}_{90}, 90$-percent flow exceedance; $\mathrm{Q}_{99}, 99$-percent flow exceedance]

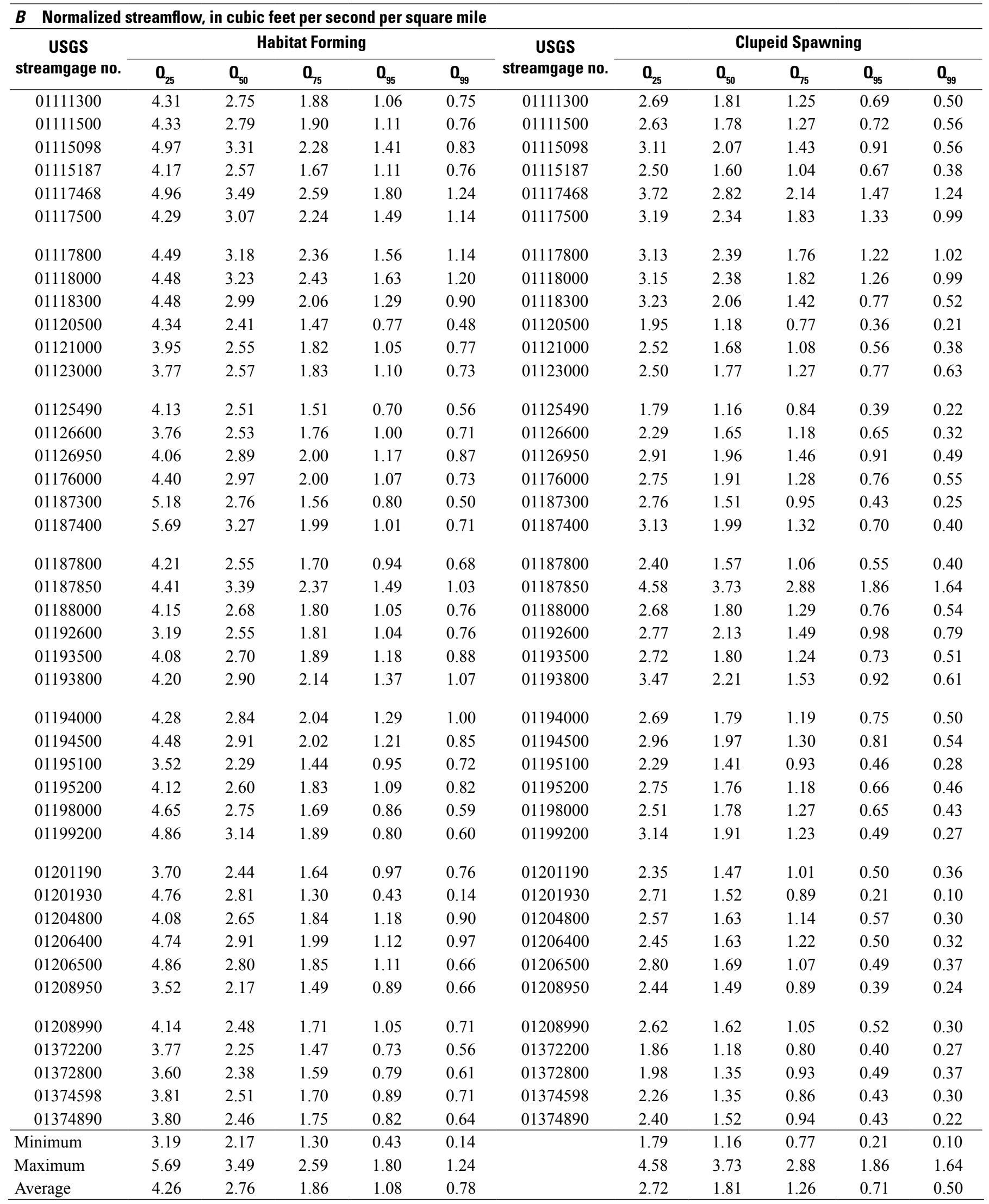


Table 3. Flow-duration statistics for streamgages with at least 10 years of continuous record in Connecticut and neighboring states considered for regression analysis: $A$, Actual streamflow; $B$, Normalized streamflow.-Continued

[USGS, U.S. Geological Survey; no. number; $\mathrm{mi}^{2}$, square miles; $\mathrm{Q}_{25}, 25$-percent flow exceedance; $\mathrm{Q}_{50}$, 50-percent flow exceedance; $\mathrm{Q}_{75}$, 75-percent flow exceedance; $\mathrm{Q}_{90}, 90$-percent flow exceedance; $\mathrm{Q}_{99}, 99$-percent flow exceedance]

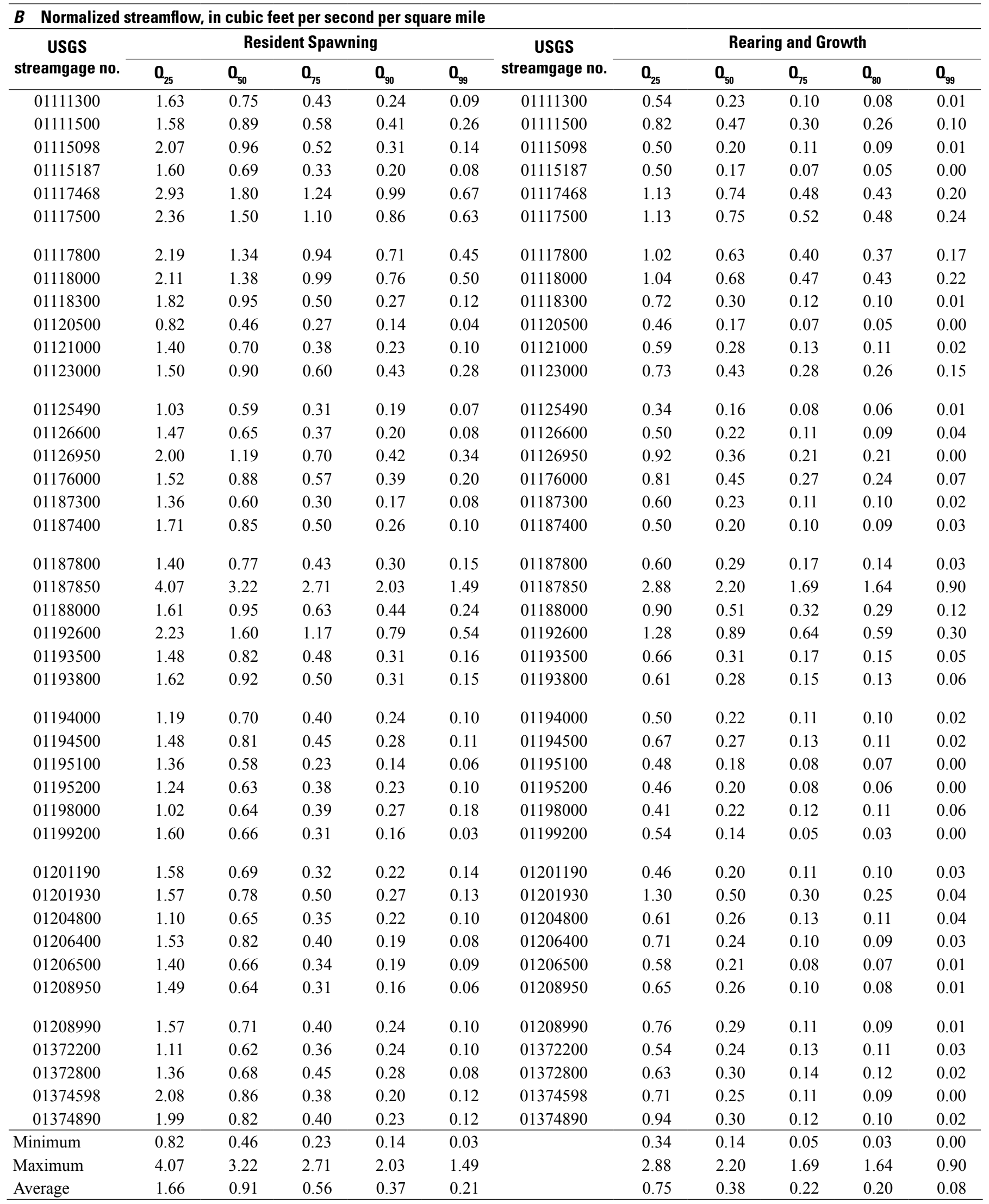


Table 5. Characteristics of the drainage basins used for regionalizing flow-duration statistics in Connecticut: $A$, Continuous streamgages; $B$, Short-term or partial-record streamgages.

[Geographic Information System used to derive all basin characteristics (table 4); USGS, U.S. Geological Survey; no., number; mi², square miles; mi, miles; $\mathrm{ft}$, feet; --, not determined; $\mathrm{Q}_{99}, 99$-percent flow exceedence]

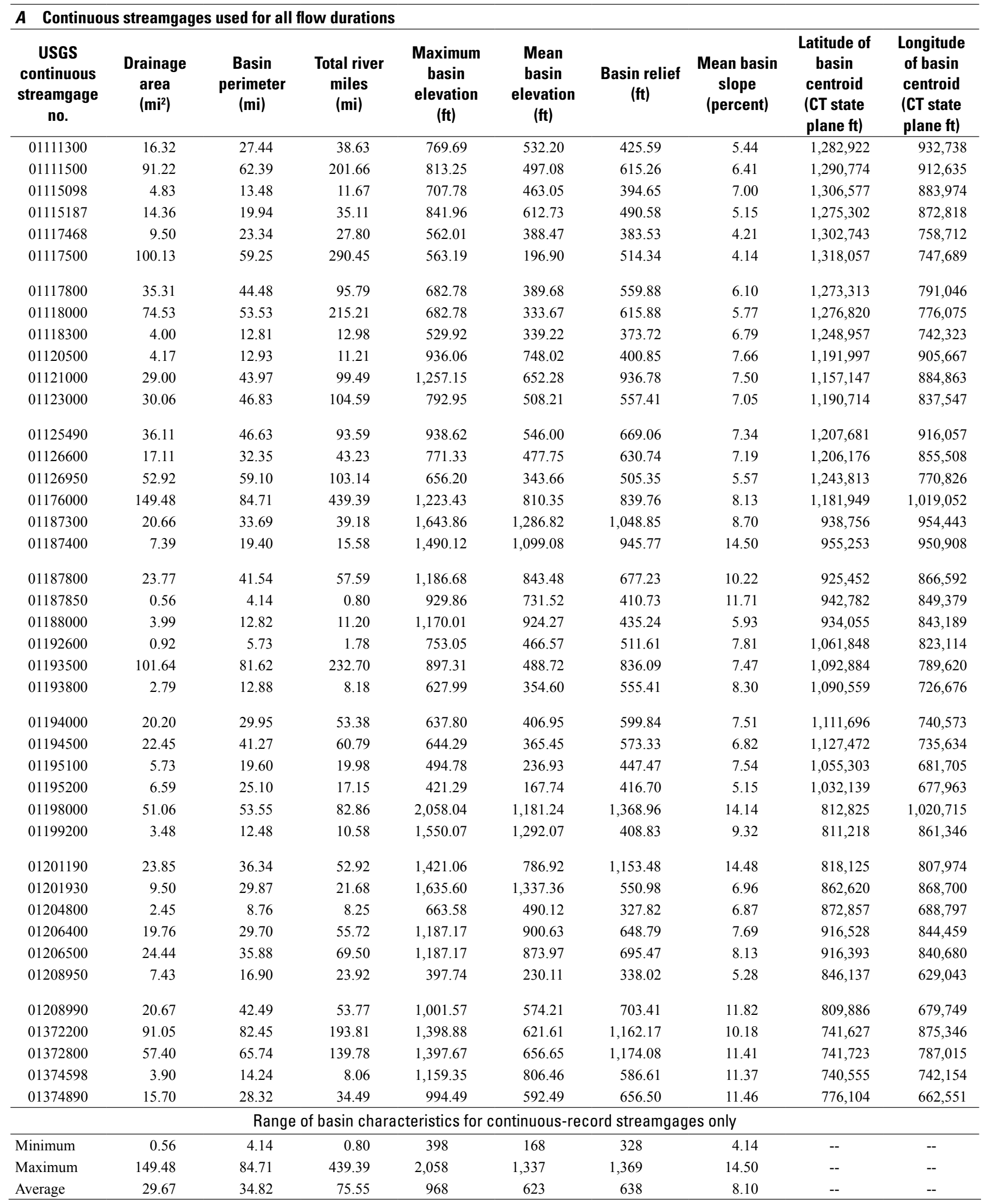


Table 5. Characteristics of the drainage basins used for regionalizing flow-duration statistics in Connecticut: $A$, Continuous streamgages; $B$, Short-term or partial-record streamgages.-Continued

[Geographic Information System used to derive all basin characteristics (table 4); USGS, U.S. Geological Survey; no., number; mi², square miles; mi, miles; $\mathrm{ft}$, feet; --, not determined; $\mathrm{Q}_{99}, 99$-percent flow exceedence]

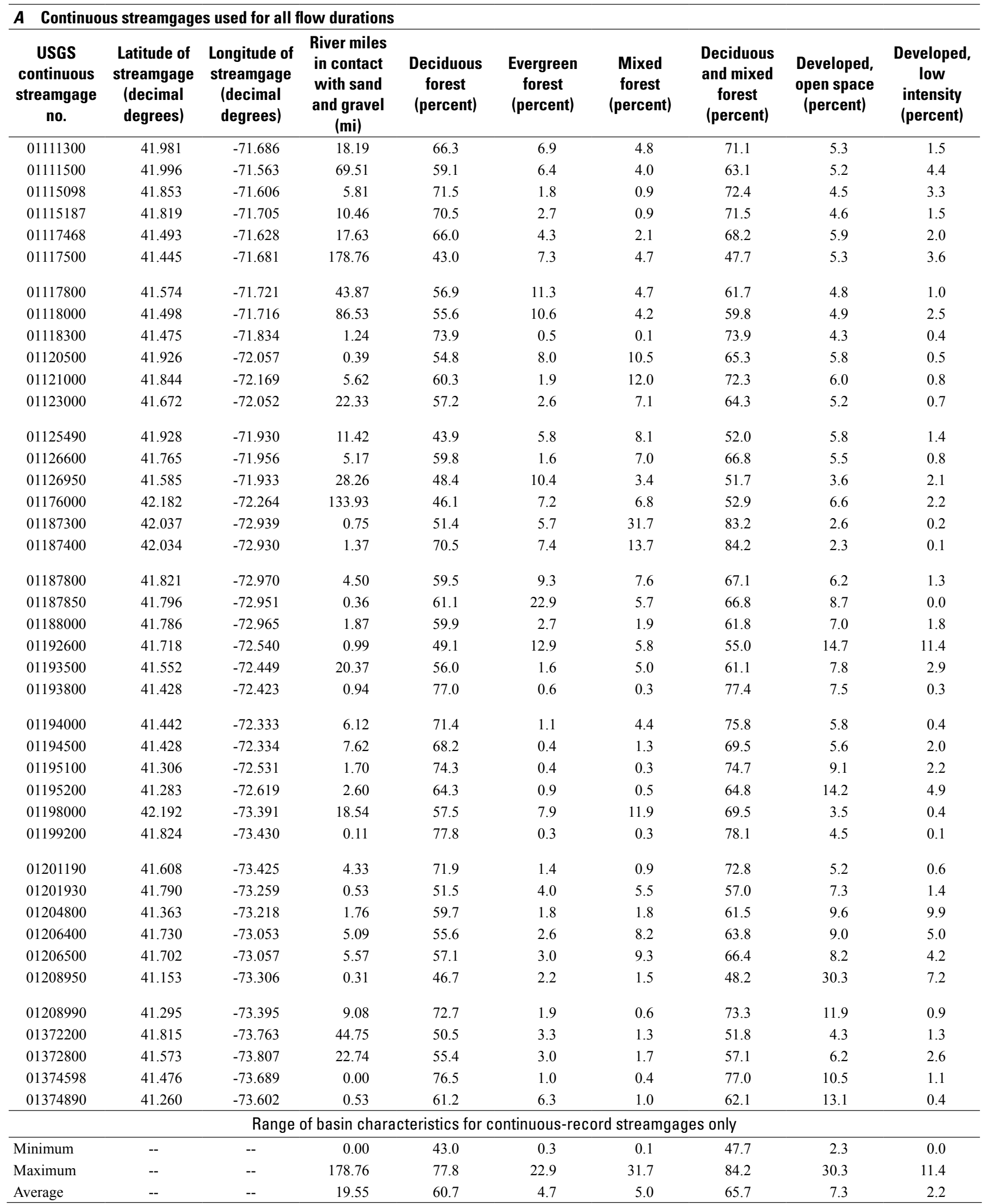


Table 5. Characteristics of the drainage basins used for regionalizing flow-duration statistics in Connecticut: $A$, Continuous streamgages; $B$, Short-term or partial-record streamgages. - Continued

[Geographic Information System used to derive all basin characteristics (table 4); USGS, U.S. Geological Survey; no., number; mi², square miles; mi, miles; $\mathrm{ft}$, feet; --, not determined; $\mathrm{Q}_{99}$, 99-percent flow exceedence]

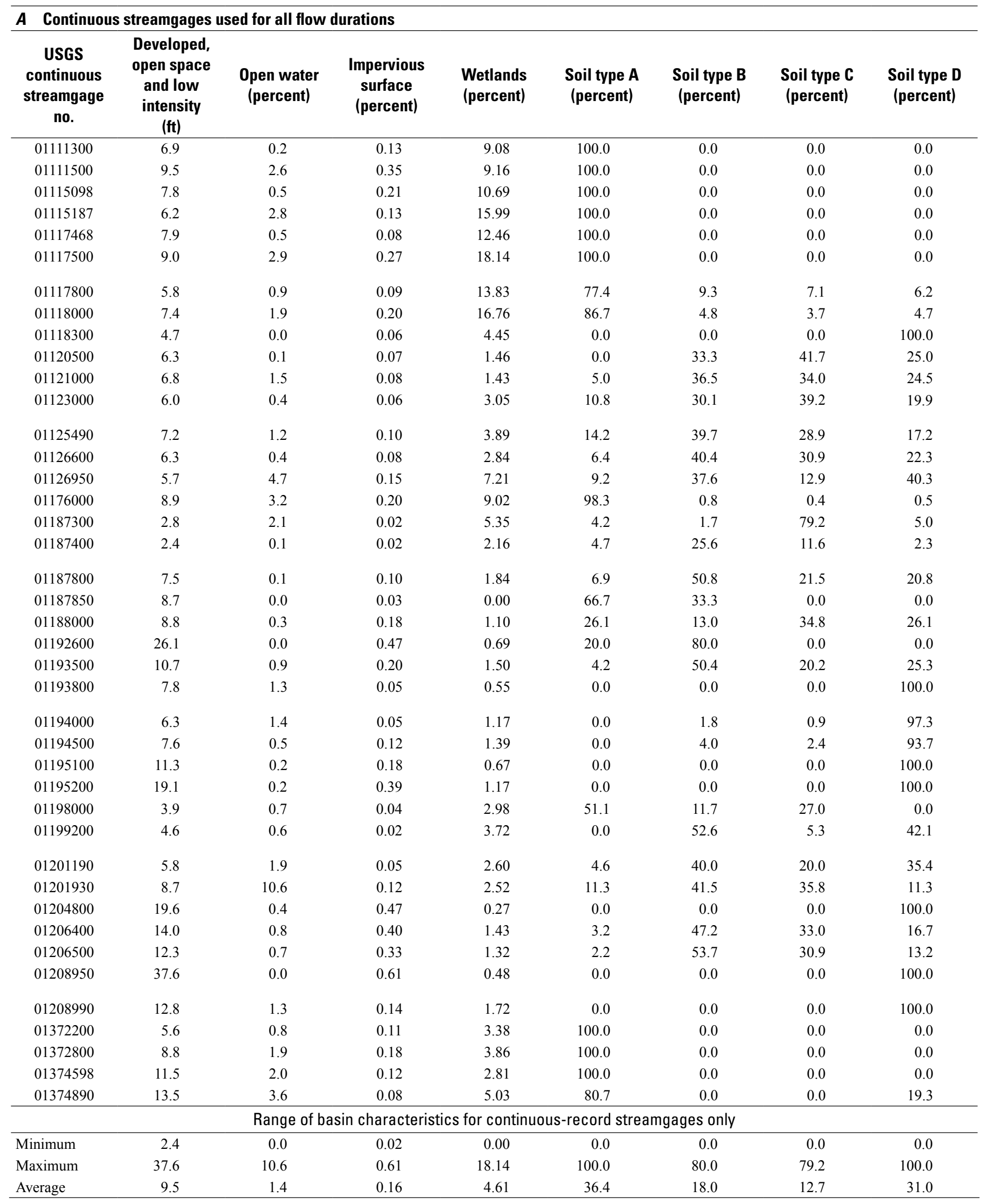


Table 5. Characteristics of the drainage basins used for regionalizing flow-duration statistics in Connecticut: $A$, Continuous streamgages; $B$, Short-term or partial-record streamgages.-Continued

[Geographic Information System used to derive all basin characteristics (table 4); USGS, U.S. Geological Survey; no., number; mi², square miles; mi, miles; $\mathrm{ft}$, feet; --, not determined; $\mathrm{Q}_{99}, 99$-percent flow exceedence]

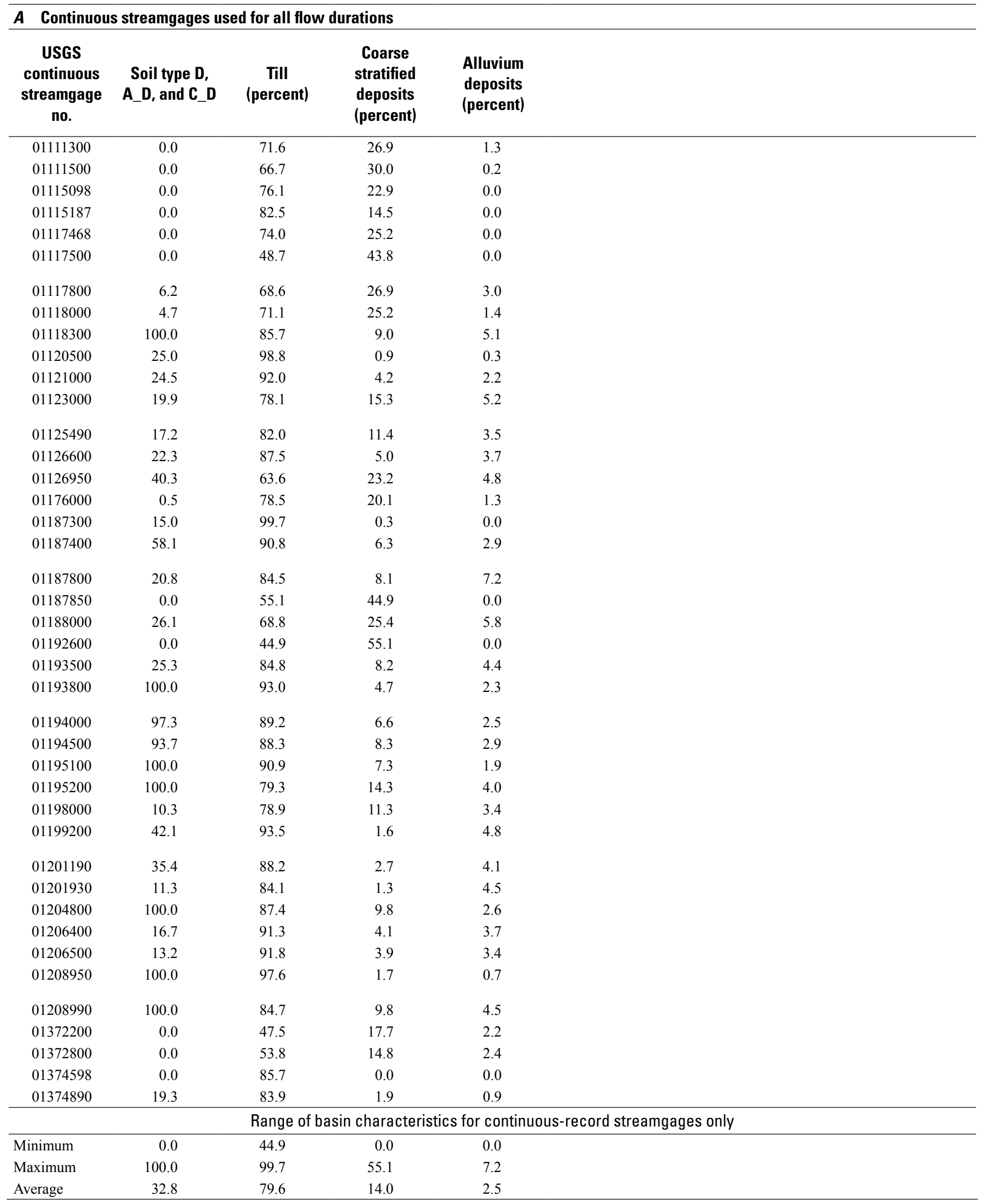


Table 5. Characteristics of the drainage basins used for regionalizing flow-duration statistics in Connecticut: $A$, Continuous streamgages; $B$, Short-term or partial-record streamgages. - Continued

[Geographic Information System used to derive all basin characteristics (table 4); USGS, U.S. Geological Survey; no., number; mi², square miles; mi, miles; $\mathrm{ft}$, feet; --, not determined; $\mathrm{Q}_{99}$, 99-percent flow exceedence]

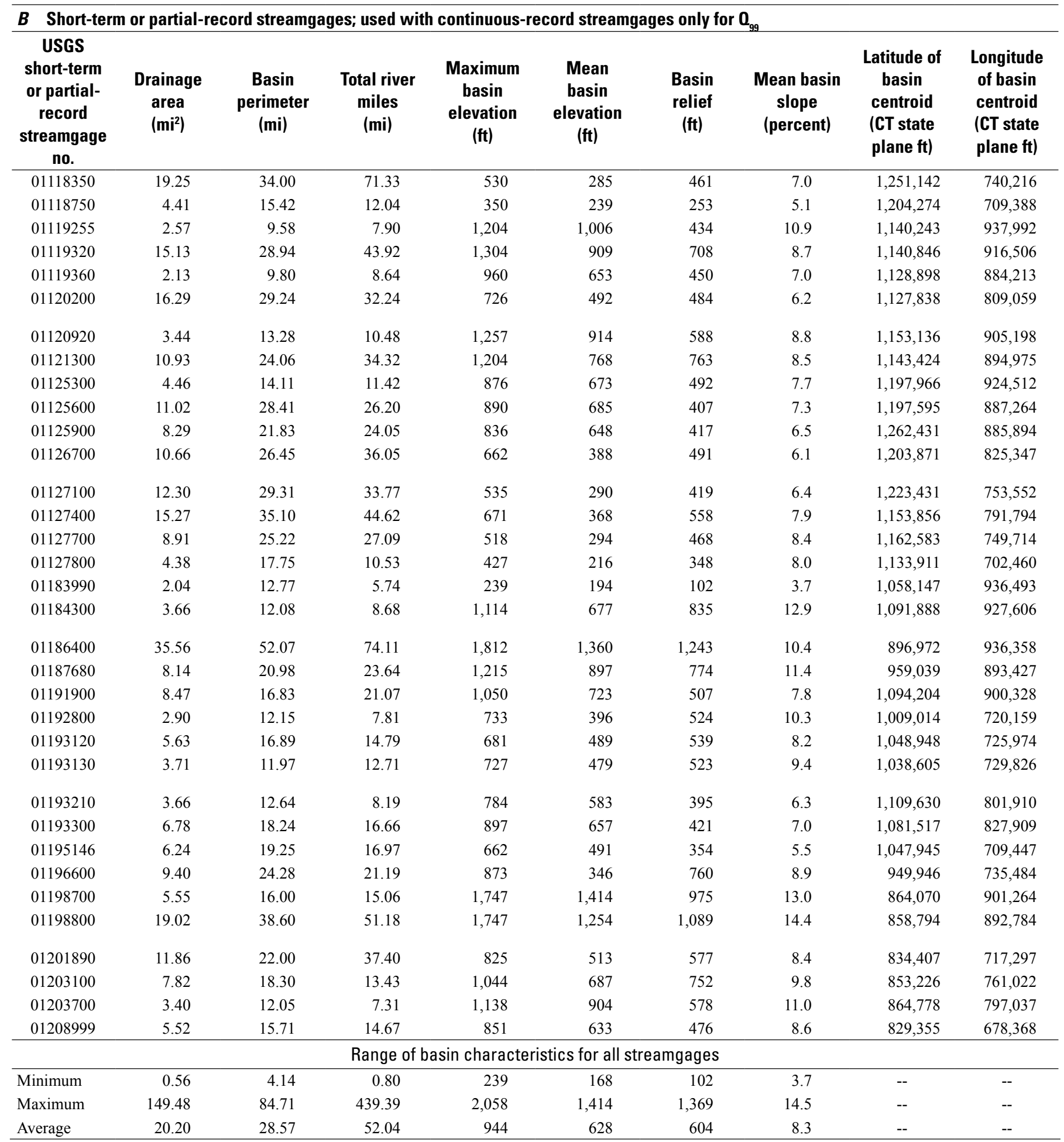


Table 5. Characteristics of the drainage basins used for regionalizing flow-duration statistics in Connecticut: $A$, Continuous streamgages; $B$, Short-term or partial-record streamgages.-Continued

[Geographic Information System used to derive all basin characteristics (table 4); USGS, U.S. Geological Survey; no., number; mi², square miles; mi, miles; $\mathrm{ft}$, feet; --, not determined; $\mathrm{Q}_{99}, 99$-percent flow exceedence]

\begin{tabular}{|c|c|c|c|c|c|c|c|c|c|}
\hline \multicolumn{10}{|c|}{ B Short-term or partial-record streamgages; used with continuous-record streamgages only for $\mathbf{0}_{99}$} \\
\hline $\begin{array}{c}\text { USGS } \\
\text { short-term } \\
\text { or partial- } \\
\text { record } \\
\text { streamgage } \\
\text { no. }\end{array}$ & $\begin{array}{l}\text { Latitude of } \\
\text { streamgage } \\
\text { (decimal } \\
\text { degrees) }\end{array}$ & $\begin{array}{l}\text { Longitude of } \\
\text { streamgage } \\
\text { (decimal } \\
\text { degrees) }\end{array}$ & $\begin{array}{l}\text { River miles } \\
\text { in contact } \\
\text { with sand } \\
\text { and gravel } \\
\text { (mi) }\end{array}$ & $\begin{array}{c}\text { Deciduous } \\
\text { forest } \\
\text { (percent) }\end{array}$ & $\begin{array}{c}\text { Evergreen } \\
\text { forest } \\
\text { (percent) }\end{array}$ & $\begin{array}{c}\text { Mixed } \\
\text { forest } \\
\text { (percent) }\end{array}$ & $\begin{array}{c}\text { Deciduous } \\
\text { and mixed } \\
\text { forest } \\
\text { (percent) }\end{array}$ & $\begin{array}{l}\text { Developed, } \\
\text { open space } \\
\text { (percent) }\end{array}$ & $\begin{array}{c}\text { Developed, } \\
\text { low } \\
\text { intensity } \\
\text { (percent) }\end{array}$ \\
\hline 01118350 & 41.455 & -71.814 & 14.88 & 73.0 & 1.5 & 0.2 & 73.2 & 3.4 & 0.6 \\
\hline 01119255 & 42.023 & -72.248 & 0.47 & 73.6 & 1.8 & 10.3 & 83.9 & 6.3 & 0.6 \\
\hline 01119320 & 41.934 & -72.261 & 0.83 & 56.3 & 7.8 & 18.9 & 75.2 & 4.6 & 0.2 \\
\hline 01119360 & 41.871 & -72.291 & 0.80 & 44.5 & 1.9 & 21.2 & 65.7 & 7.2 & 0.8 \\
\hline 01120200 & 41.707 & -72.247 & 1.89 & 64.2 & 0.5 & 2.9 & 67.1 & 4.4 & 1.3 \\
\hline 01120920 & 41.920 & -72.179 & 0.34 & 62.9 & 2.5 & 6.1 & 68.9 & 10.1 & 0.9 \\
\hline 01126700 & 41.681 & -71.978 & 14.00 & 56.2 & 0.6 & 5.0 & 61.2 & 4.5 & 0.8 \\
\hline 01127100 & 41.554 & -71.970 & 9.93 & 52.9 & 0.7 & 0.2 & 53.2 & 2.8 & 0.9 \\
\hline 01127400 & 41.571 & -72.133 & 8.17 & 50.6 & 0.7 & 3.2 & 53.8 & 4.3 & 1.5 \\
\hline 01127700 & 41.501 & -72.116 & 4.89 & 75.1 & 0.5 & 1.1 & 76.2 & 5.2 & 3.2 \\
\hline 01127800 & 41.357 & -72.261 & 1.11 & 78.3 & 0.2 & 0.1 & 78.4 & 2.6 & 1.0 \\
\hline 01183990 & 42.007 & -72.553 & 1.59 & 25.2 & 5.5 & 1.2 & 26.4 & 15.4 & 14.8 \\
\hline 01184300 & 41.992 & -72.434 & 0.77 & 73.0 & 3.6 & 4.6 & 77.6 & 6.4 & 1.3 \\
\hline 01186400 & 41.978 & -73.045 & 5.92 & 54.6 & 5.8 & 23.7 & 78.3 & 4.2 & 0.2 \\
\hline 01187680 & 41.872 & -72.906 & 0.00 & 76.4 & 3.1 & 4.0 & 80.4 & 5.5 & 0.6 \\
\hline 01196600 & 41.460 & -72.918 & 8.48 & 54.1 & 1.0 & 0.6 & 54.7 & 15.4 & 15.3 \\
\hline 01198700 & 41.926 & -73.280 & 0.04 & 70.3 & 7.3 & 12.7 & 83.1 & 1.0 & 0.0 \\
\hline 01198800 & 41.949 & -73.321 & 2.87 & 68.8 & 8.4 & 10.1 & 78.9 & 2.9 & 0.2 \\
\hline 01201890 & 41.456 & -73.335 & 3.65 & 59.2 & 1.1 & 1.0 & 60.2 & 10.5 & 7.3 \\
\hline 01203100 & 41.528 & -73.308 & 0.54 & 67.0 & 0.7 & 1.5 & 68.5 & 7.4 & 0.7 \\
\hline 01203700 & 41.627 & -73.226 & 0.08 & 76.0 & 0.7 & 0.2 & 76.2 & 5.9 & 0.2 \\
\hline 01208999 & 41.293 & -73.368 & 0.77 & 76.7 & 1.2 & 0.2 & 76.9 & 8.0 & 0.9 \\
\hline \multicolumn{10}{|c|}{ Range of basin characteristics for all streamgages } \\
\hline Minimum & -- & -- & 0.00 & 25.2 & 0.2 & 0.0 & 26.4 & 1.0 & 0.0 \\
\hline Maximum & -- & -- & 178.76 & 81.7 & 22.9 & 31.7 & 86.8 & 30.3 & 15.3 \\
\hline Average & -- & -- & 12.17 & 62.2 & 3.7 & 5.2 & 67.4 & 6.8 & 2.2 \\
\hline
\end{tabular}


Table 5. Characteristics of the drainage basins used for regionalizing flow-duration statistics in Connecticut: $A$, Continuous streamgages; $B$, Short-term or partial-record streamgages.-Continued

[Geographic Information System used to derive all basin characteristics (table 4); USGS, U.S. Geological Survey; no., number; mi², square miles; mi, miles; $\mathrm{ft}$, feet; --, not determined; $\mathrm{Q}_{99}, 99$-percent flow exceedence]

\begin{tabular}{|c|c|c|c|c|c|c|c|c|}
\hline \multicolumn{9}{|c|}{$B \quad$ Short-term or partial-record streamgages; used with continuous-record streamgages only for $\mathbf{Q}_{99}$} \\
\hline $\begin{array}{c}\text { USGS short- } \\
\text { term } \\
\text { or partial- } \\
\text { record } \\
\text { streamgage } \\
\text { no. }\end{array}$ & $\begin{array}{c}\text { Developed, } \\
\text { open space } \\
\text { and low } \\
\text { intensity } \\
\text { (ft) }\end{array}$ & $\begin{array}{c}\text { Open water } \\
\text { (percent) }\end{array}$ & $\begin{array}{l}\text { Impervious } \\
\text { surface } \\
\text { (percent) }\end{array}$ & $\begin{array}{l}\text { Wetlands } \\
\text { (percent) }\end{array}$ & $\begin{array}{c}\text { Soil Type A } \\
\text { (percent) }\end{array}$ & $\begin{array}{c}\text { Soil type B } \\
\text { (percent) }\end{array}$ & $\begin{array}{c}\text { Soil type C } \\
\text { (percent) }\end{array}$ & $\begin{array}{c}\text { Soil type D } \\
\text { (percent) }\end{array}$ \\
\hline 01118350 & 4.0 & 1.3 & 0.06 & 6.7 & 0.0 & 0.4 & 0.0 & 99.6 \\
\hline 01119255 & 6.9 & 0.3 & 0.06 & 2.7 & 0.0 & 18.8 & 43.7 & 31.3 \\
\hline 01119320 & 4.8 & 1.4 & 0.03 & 1.3 & 2.5 & 49.4 & 11.1 & 37.0 \\
\hline 01119360 & 8.0 & 0.9 & 0.08 & 2.8 & 0.0 & 63.6 & 0.0 & 36.4 \\
\hline 01120200 & 5.7 & 0.8 & 0.09 & 1.3 & 3.3 & 35.6 & 37.8 & 23.3 \\
\hline 01120920 & 11.0 & 4.5 & 0.15 & 1.4 & 14.9 & 25.5 & 40.4 & 19.1 \\
\hline 01126700 & 5.3 & 0.4 & 0.07 & 4.3 & 10.3 & 46.6 & 25.9 & 17.2 \\
\hline 01127100 & 3.7 & 0.0 & 0.07 & 2.3 & 1.4 & 15.7 & 7.1 & 75.7 \\
\hline 01127400 & 5.8 & 0.1 & 0.12 & 0.8 & 2.3 & 32.6 & 50.0 & 15.1 \\
\hline 01127700 & 8.3 & 0.5 & 0.25 & 0.4 & 0.0 & 6.0 & 6.0 & 88.0 \\
\hline 01127800 & 3.6 & 1.2 & 0.06 & 1.9 & 0.0 & 0.0 & 0.0 & 100.0 \\
\hline 01183990 & 30.3 & 2.1 & 1.53 & 4.1 & 36.4 & 36.4 & 0.0 & 27.3 \\
\hline 01184300 & 7.7 & 1.1 & 0.09 & 0.5 & 0.0 & 38.1 & 19.0 & 42.9 \\
\hline 01186400 & 4.5 & 2.0 & 0.04 & 5.3 & 1.0 & 29.2 & 33.2 & 31.7 \\
\hline 01187680 & 6.1 & 0.4 & 0.06 & 0.4 & 0.0 & 71.1 & 20.0 & 8.9 \\
\hline 01196600 & 30.7 & 0.1 & 0.99 & 0.6 & 0.0 & 0.0 & 0.0 & 100.0 \\
\hline 01198700 & 1.0 & 1.0 & 0.00 & 2.4 & 1.2 & 53.7 & 1.2 & 43.9 \\
\hline 01198800 & 3.1 & 0.4 & 0.03 & 1.5 & 2.8 & 54.2 & 14.0 & 29.0 \\
\hline 01201890 & 17.9 & 1.9 & 0.52 & 0.7 & 0.0 & 0.0 & 0.0 & 100.0 \\
\hline 01203100 & 8.2 & 0.1 & 0.09 & 0.5 & 0.0 & 25.0 & 11.4 & 63.6 \\
\hline 01203700 & 6.1 & 0.6 & 0.05 & 0.5 & 0.0 & 59.6 & 25.5 & 14.9 \\
\hline 01208999 & 8.9 & 0.4 & 0.10 & 0.2 & 0.0 & 0.0 & 0.0 & 100.0 \\
\hline \multicolumn{9}{|c|}{ Range of basin characteristics for all streamgages } \\
\hline Minimum & 1.0 & 0.0 & 0.00 & 0.0 & 0.0 & 0.0 & 0.0 & 0.0 \\
\hline Maximum & 37.6 & 10.6 & 1.53 & 18.1 & 100 & 80.0 & 79.2 & 100.0 \\
\hline Average & 9.0 & 1.1 & 0.08 & 3.6 & 23.0 & 22.6 & 15.0 & 40.2 \\
\hline
\end{tabular}


Table 5. Characteristics of the drainage basins used for regionalizing flow-duration statistics in Connecticut: $A$, Continuous streamgages; $B$, Short-term or partial-record streamgages.-Continued

[Geographic Information System used to derive all basin characteristics (table 4); USGS, U.S. Geological Survey; no., number; mi², square miles; mi, miles; $\mathrm{ft}$, feet; --, not determined; $\mathrm{Q}_{99}, 99$-percent flow exceedence]

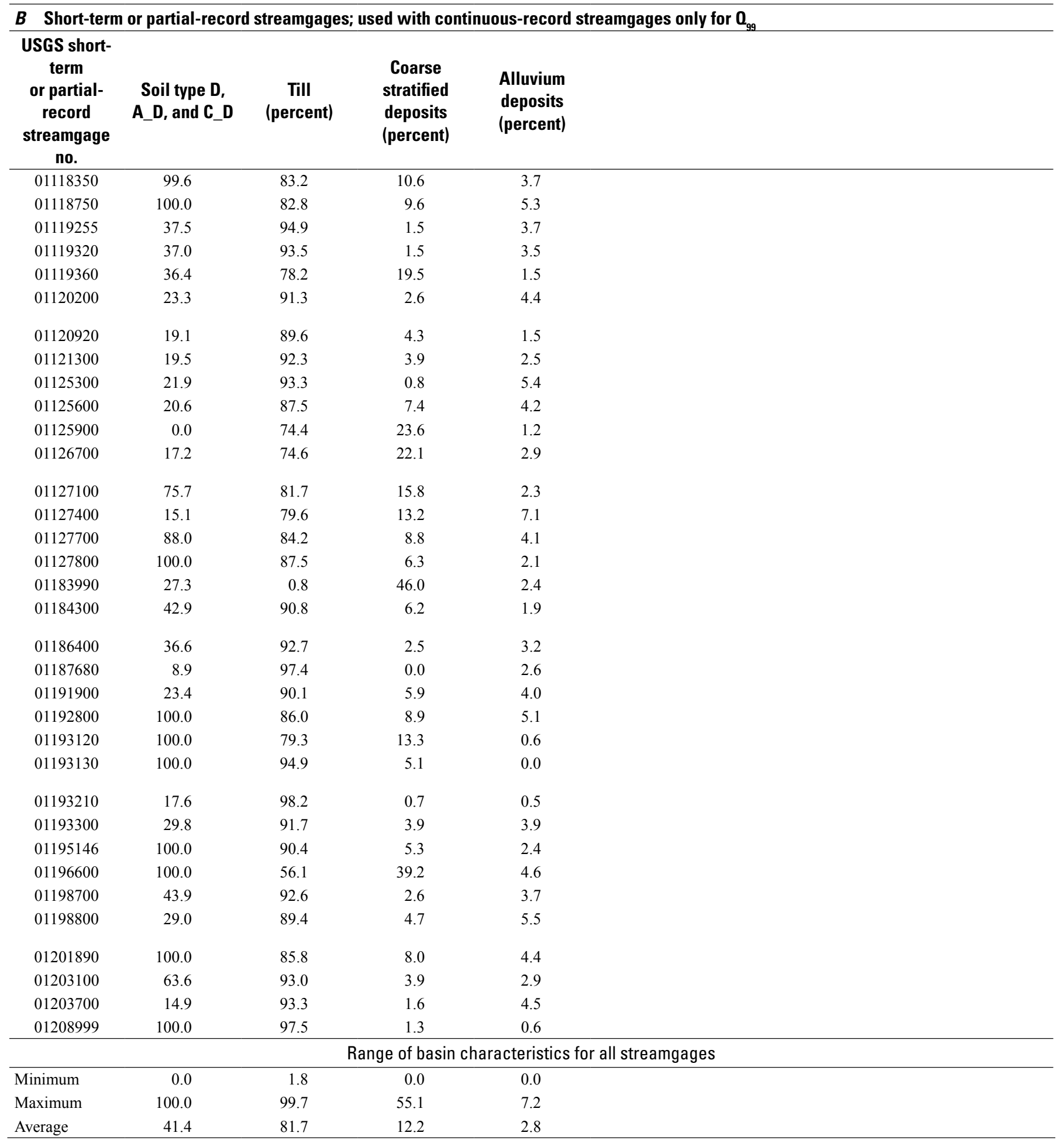


Table 6. Climate characteristics used for regionalizing flow-duration statistics in Connecticut.

[Climate characteristics are basinwide averages for the streamgages. USGS, U.S. Geological Survey; no., number; Precip, precipitation, in inches; Temp, temperature, in degrees Fahrenheit]

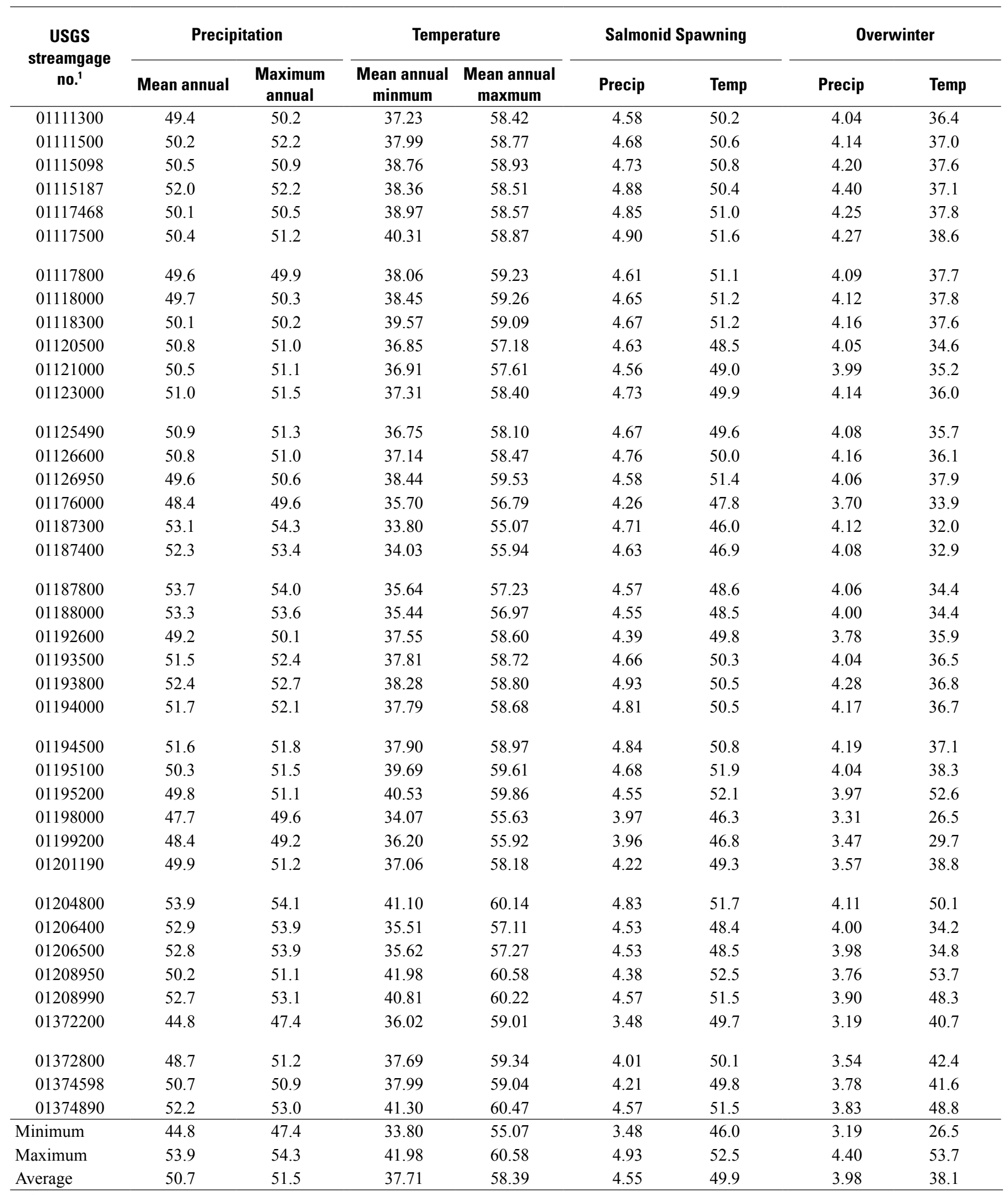

${ }^{1}$ Clear Brook (01187850) and Marshepaug River (01201930) are not included in this data set. 
Table 6. Climate characteristics used for regionalizing flow-duration statistics in Connecticut.-Continued

[Climate characteristics are basinwide averages for the streamgages. USGS, U.S. Geological Survey; no., number; Precip, precipitation, in inches; Temp, temperature, in degrees Fahrenheit]

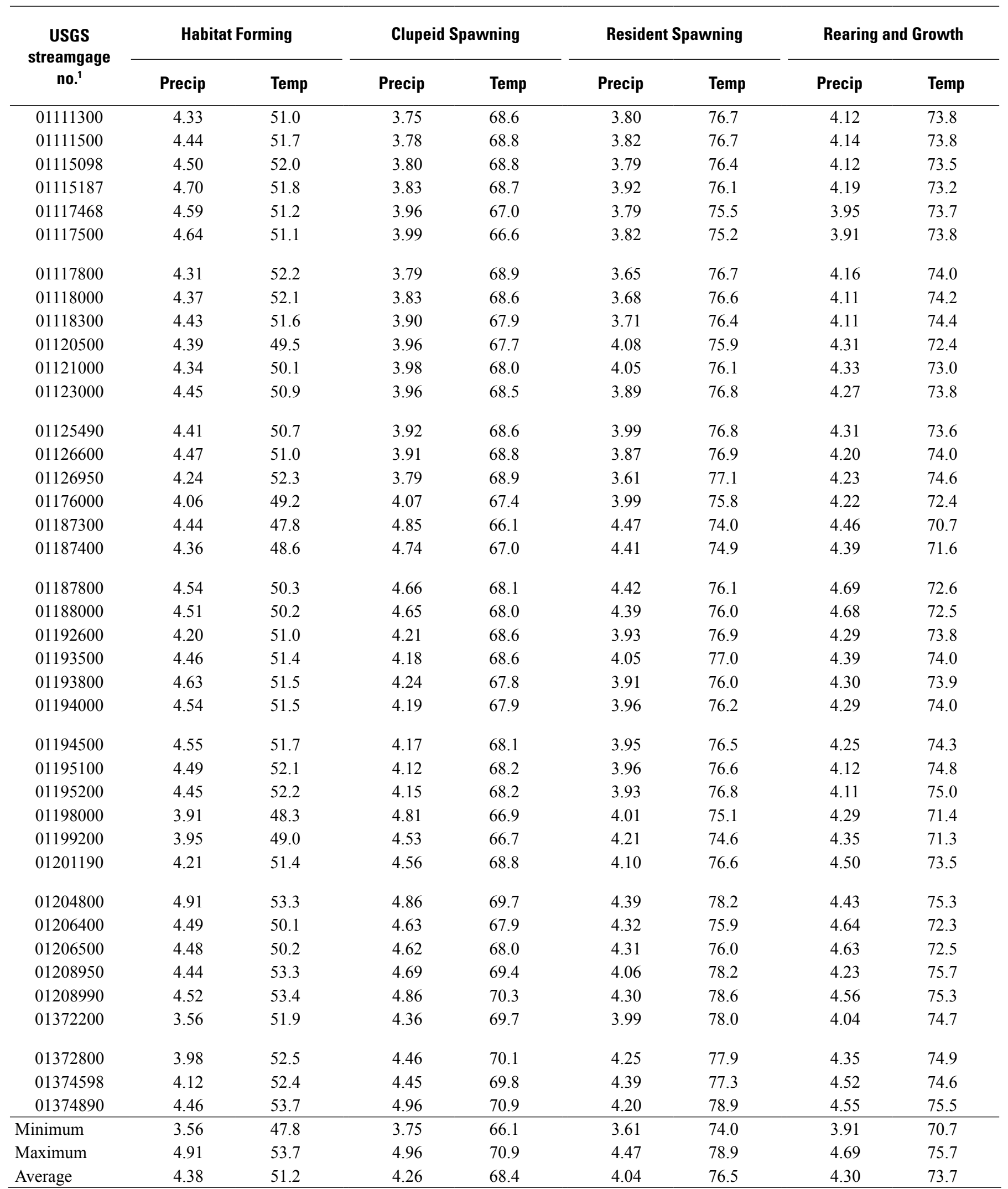




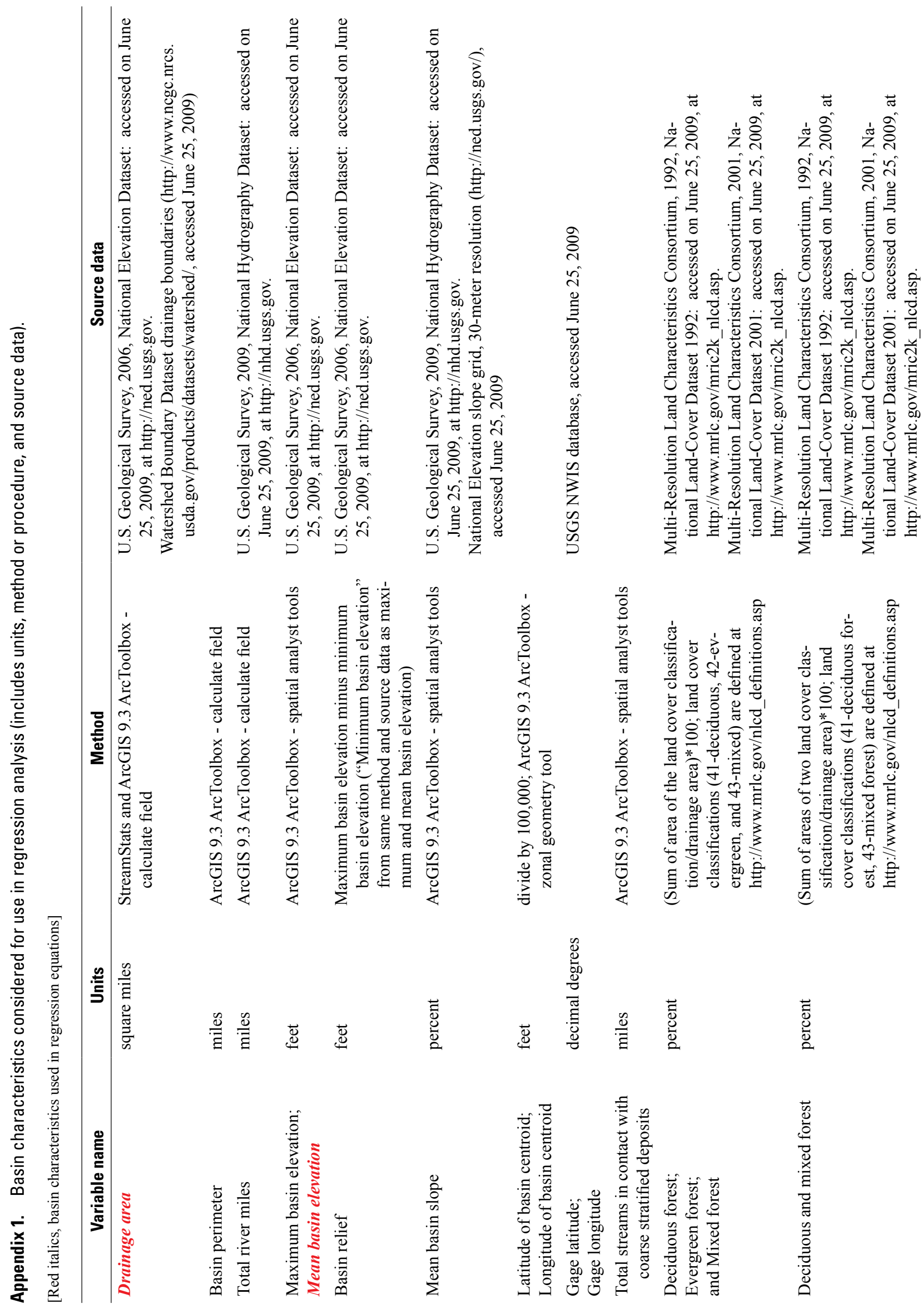




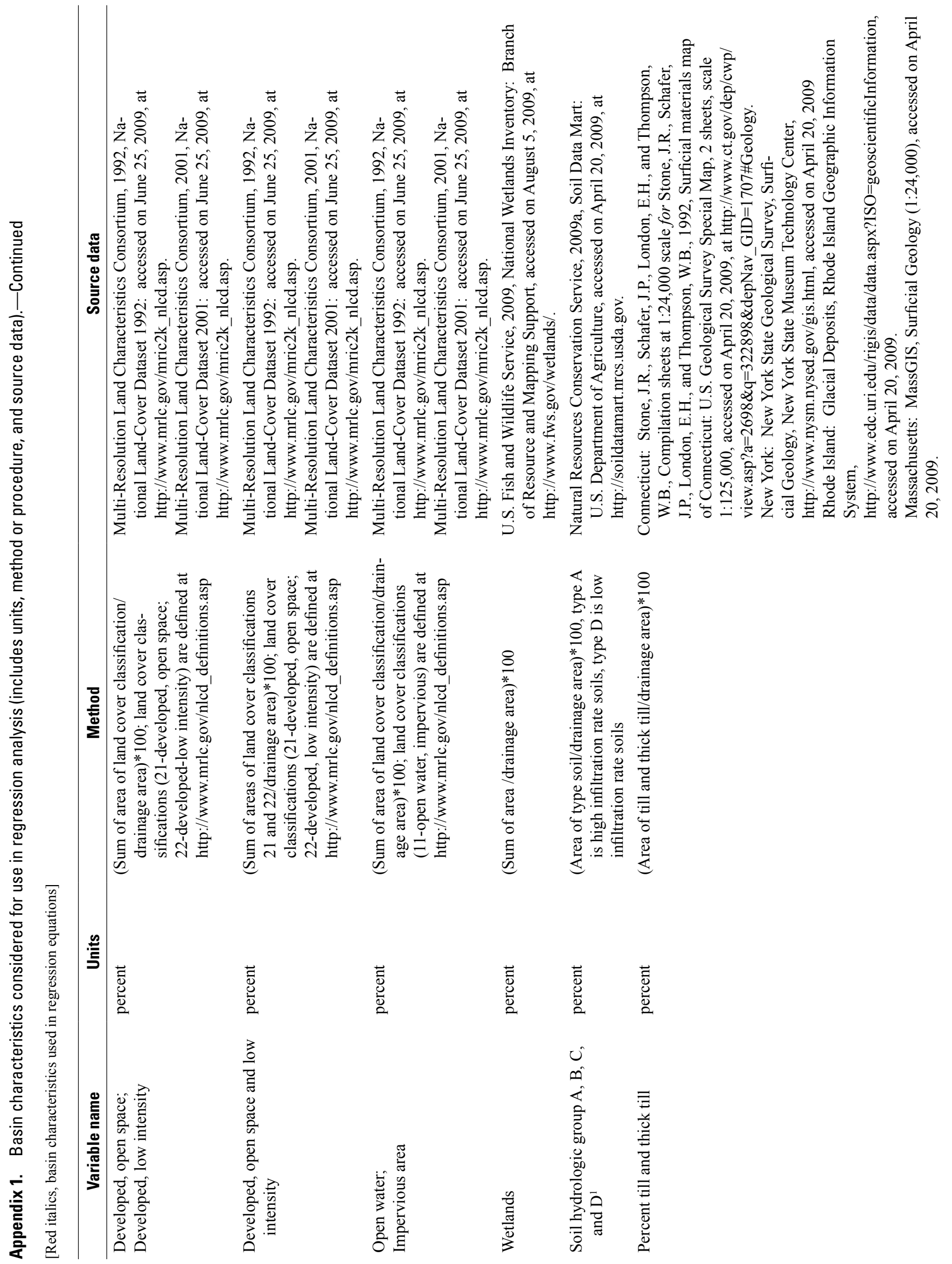




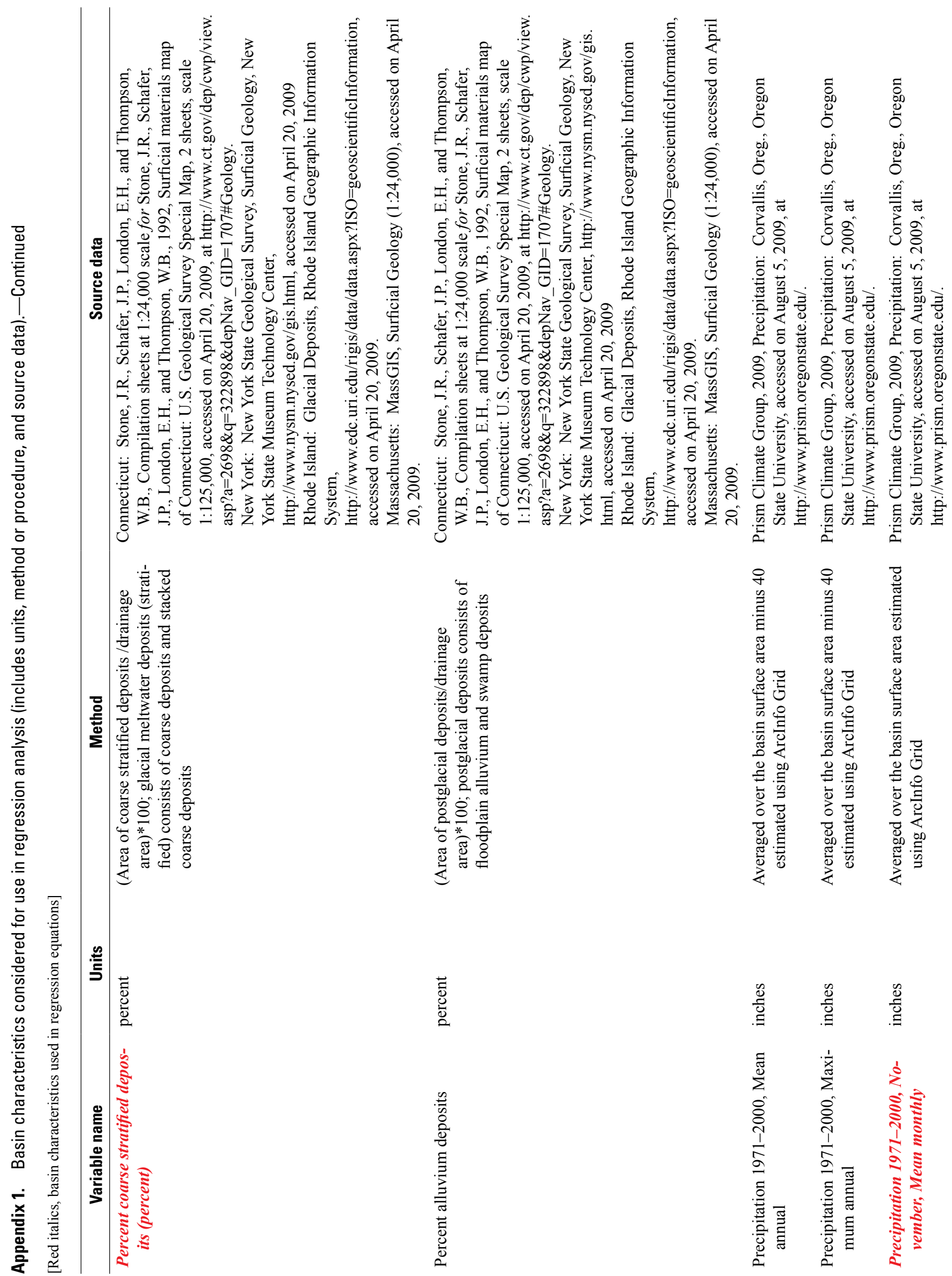




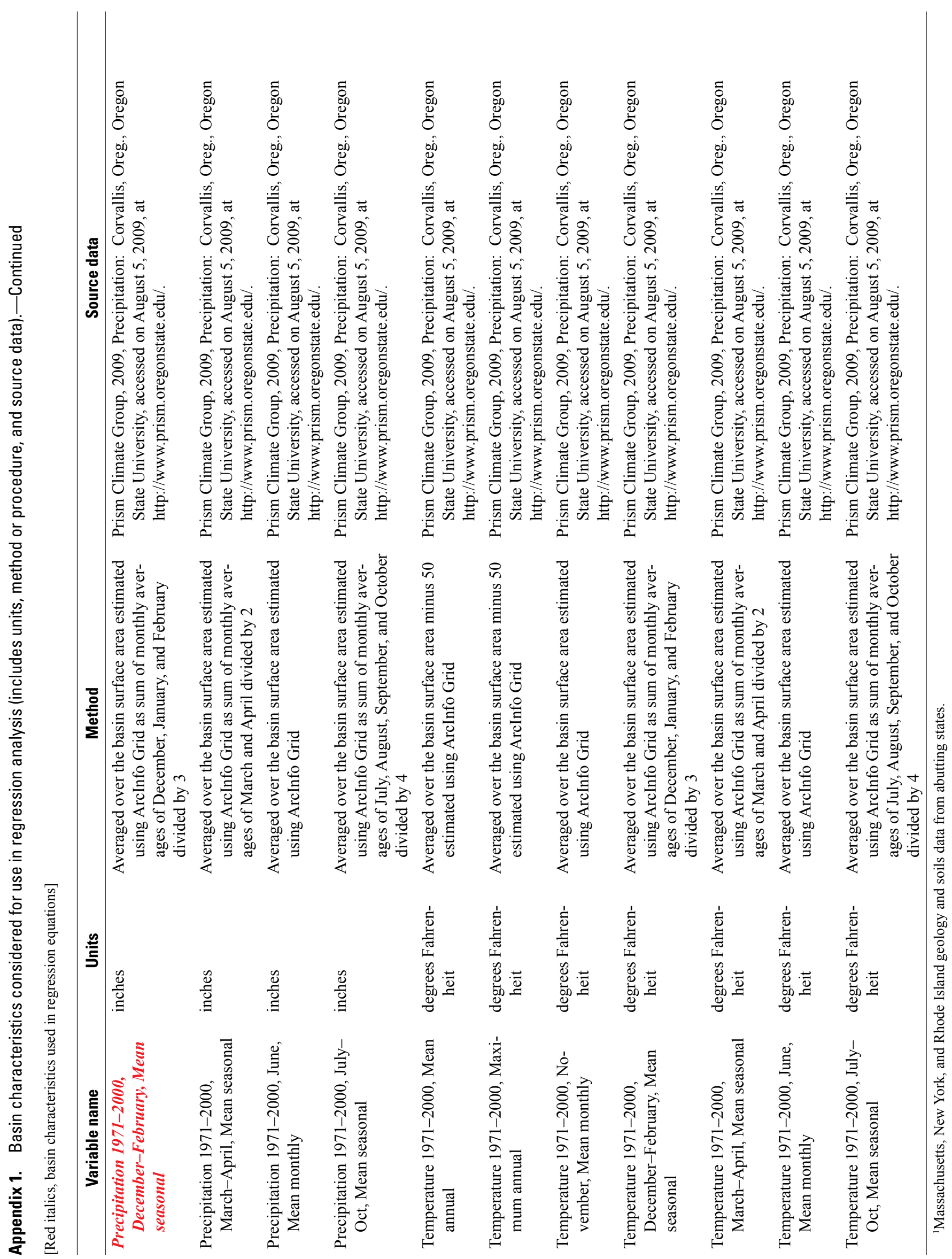




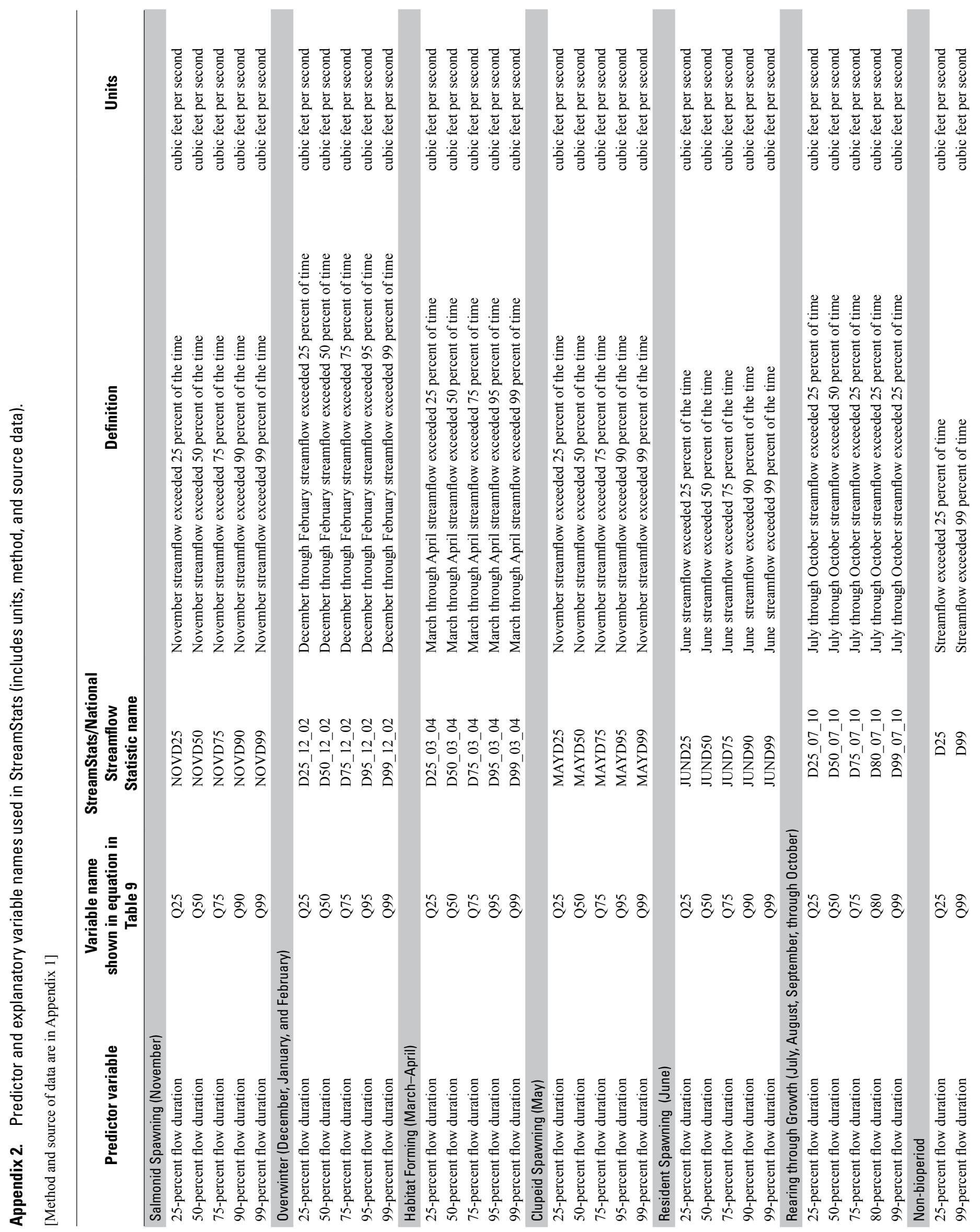




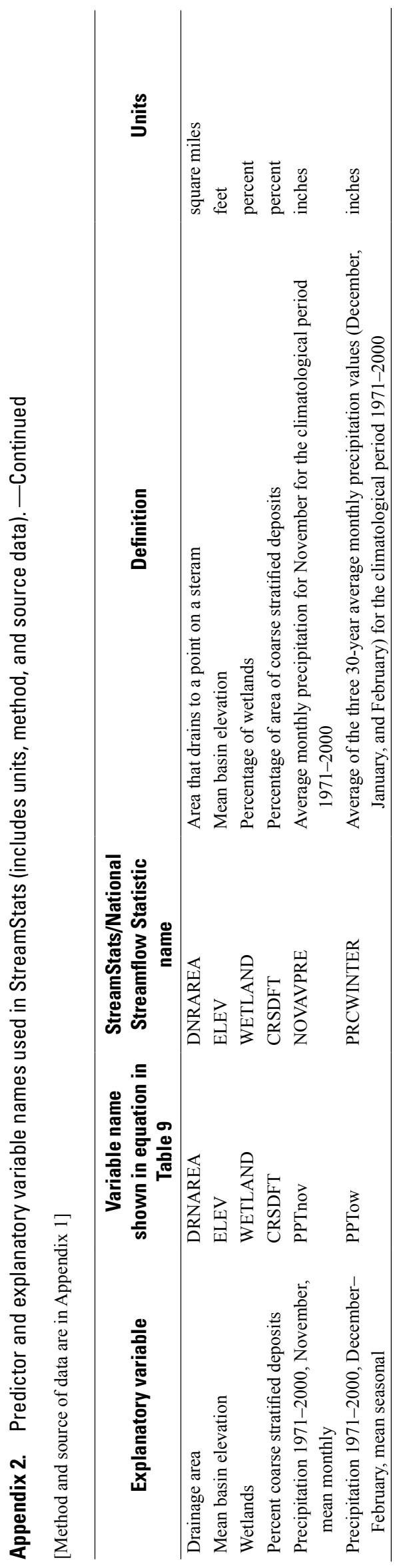


THIS PAGE INTENTIONALLY LEFT BLANK 
THIS PAGE INTENTIONALLY LEFT BLANK 
THIS PAGE INTENTIONALLY LEFT BLANK 
Prepared by the West Trenton and Pembroke Publishing Service Centers.

For more information concerning this report, contact:

Director

U.S. Geological Survey

Connecticut Water Science Center

101 Pitkin Street

East Hartford, CT 06108

dc_ct@usgs.gov

(860) 291-6741

or visit our web site at:

http://ct.water.usgs.gov 
